NISTIR 8289

\title{
Quantities and Units for Software Product Measurements
}

David Flater

This publication is available free of charge from:

https://doi.org/10.6028/NIST.IR.8289

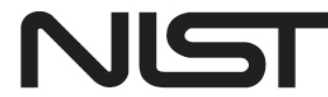

National Institute of Standards and Technology U.S. Department of Commerce 
NISTIR 8289

\section{Quantities and Units for Software Product Measurements}

David Flater

Software and Systems Division

Information Technology Laboratory

This publication is available free of charge from:

https://doi.org/10.6028/NIST.IR.8289

March 2020

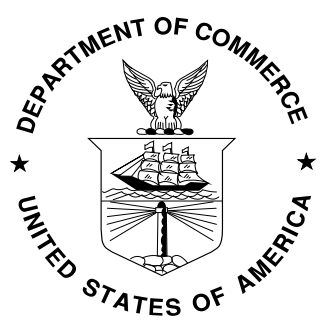

U.S. Department of Commerce Wilbur L. Ross, Jr., Secretary

National Institute of Standards and Technology Walter Copan, NIST Director and Undersecretary of Commerce for Standards and Technology 
Certain commercial entities, equipment, or materials may be identified in this document in order to describe an experimental procedure or concept adequately. Such identification is not intended to imply recommendation or endorsement by the National Institute of Standards and Technology, nor is it intended to imply that the entities, materials, or equipment are necessarily the best available for the purpose.

National Institute of Standards and Technology Interagency or Internal Report 8289

Natl. Inst. Stand. Technol. Interag. Intern. Rep. 8289, 82 pages (March 2020)

This publication is available free of charge from: https://doi.org/10.6028/NIST.IR.8289 


\begin{abstract}
International Organization for Standardization (ISO)/International Electrotechnical Commission (IEC) 80000, the International System of Quantities, collects and organizes the most important physical quantities into a coherent system. In a similar fashion, this report collects and organizes the most important quantities used in software metrics, focusing on software as a product rather than its development process.
\end{abstract}

\title{
Key words
}

Measurement; metrics; quantities; software; units. 


\section{Table of Contents}

0 Measurement concepts ................................................................................................................ 1

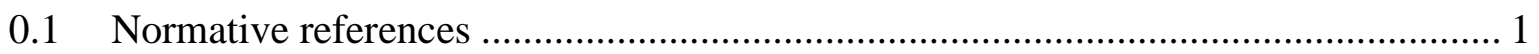

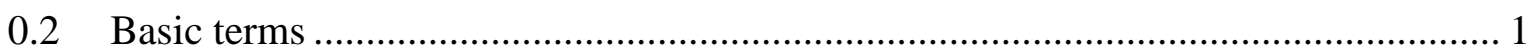

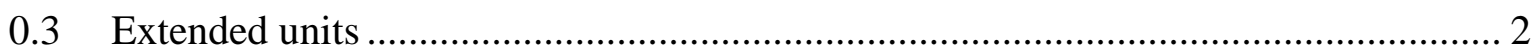

0.4 "Amount of data" as a dimension .................................................................. 2

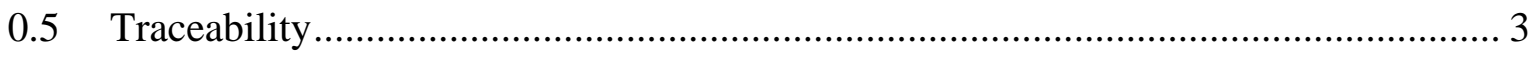

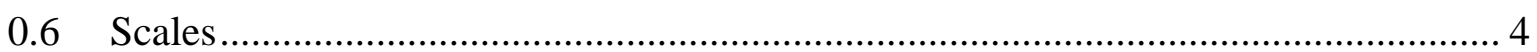

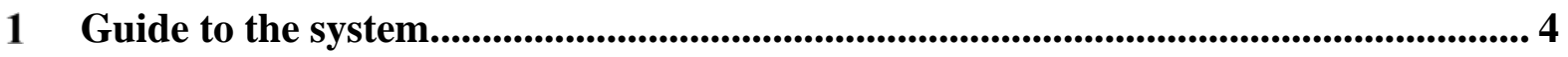

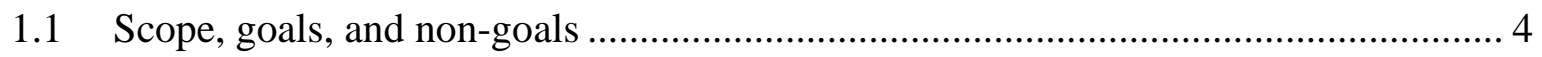

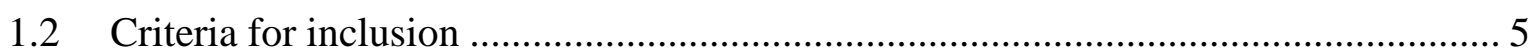

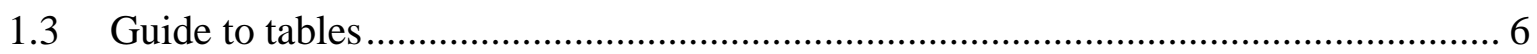

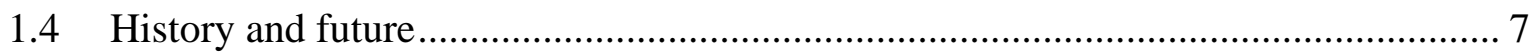

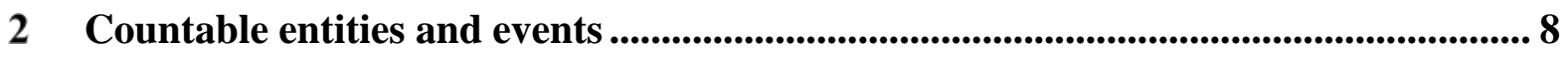

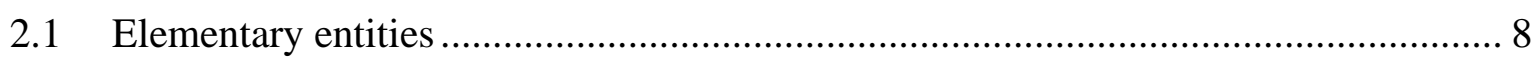

2.2 Source-level entities .................................................................................. 9

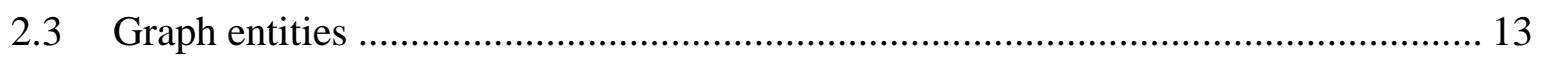

2.4 Dependency and definition/use entities......................................................... 14

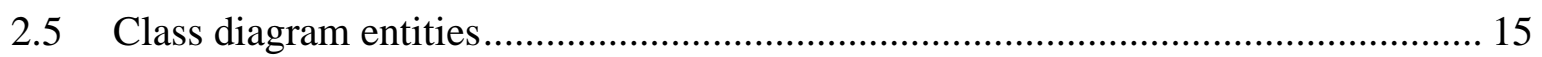

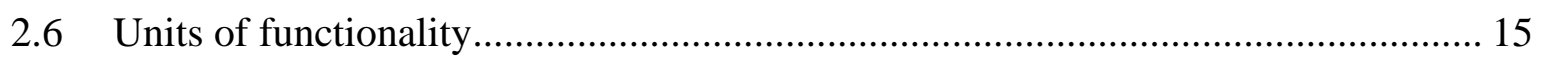

2.7 Units of failure, interruption, and termination ................................................... 18

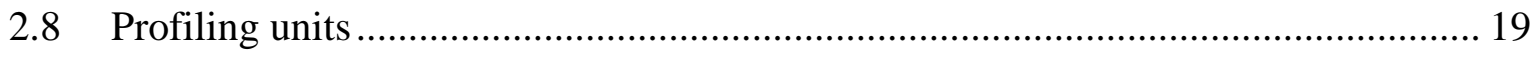

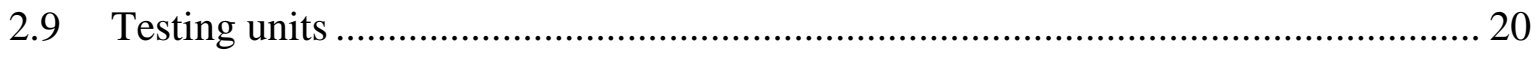

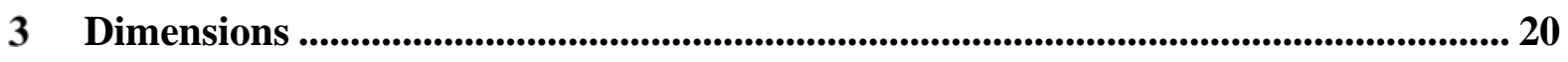

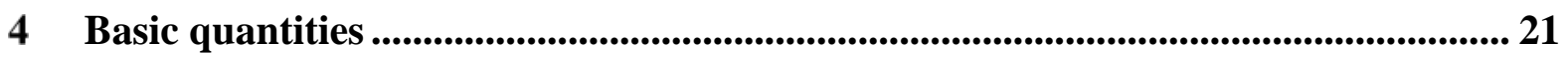

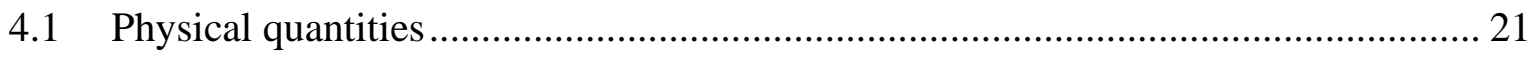

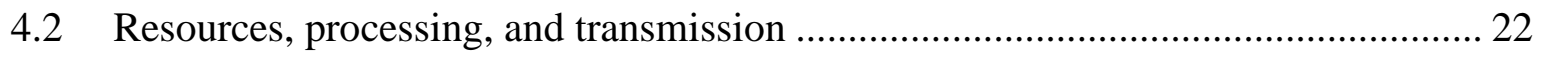

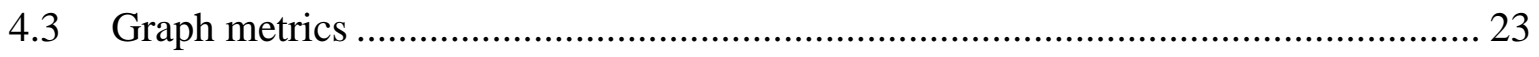

5 Compatibility metrics.......................................................................................... 24

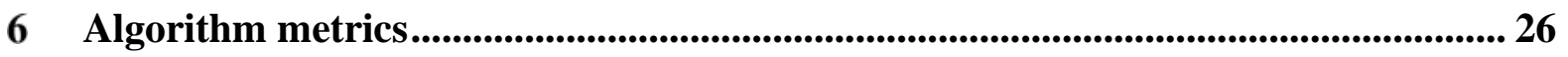

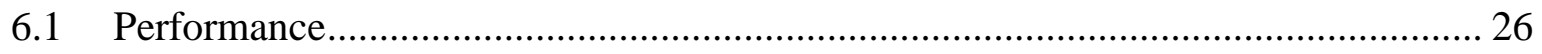

6.2 Hash function metrics................................................................................. 26

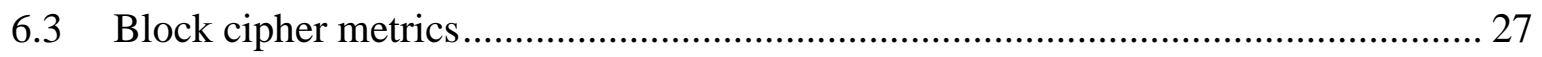

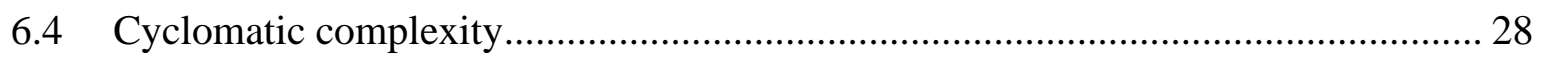


6.5 Woodward, Hennell, and Hedley complexity .................................................. 29

7 General design and implementation metrics...................................................... 29

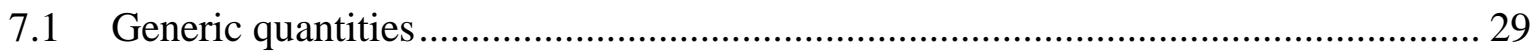

7.2 Belady and Evangelisti clustering complexity metric ......................................... 30

7.3 Henry and Kafura information flow complexity metric....................................... 31

7.4 Cruickshank and Gaffney coupling metric......................................................... 32

7.5 Structured Design scales of coupling and cohesion ........................................... 32

7.6 Embley and Woodfield scales of coupling and cohesion ..................................... 34

7.7 Briand, Morasca, and Basili metrics ............................................................... 34

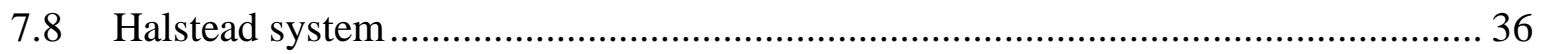

7.9 Functional size (of a software application) .................................................... 38

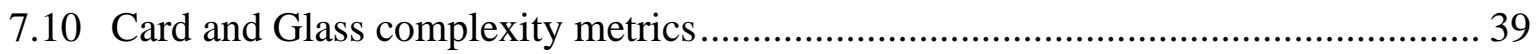

7.11 Program Complexity Analysis Methodology (PCAM) metrics ............................. 40

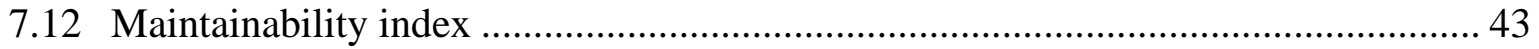

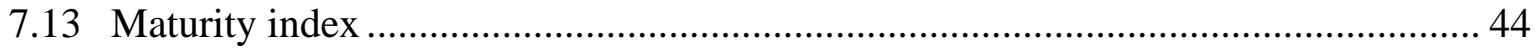

8 Object-oriented design and implementation metrics .......................................... 45

8.1 Eder, Kappel, and Schrefl scales of coupling and cohesion.................................. 45

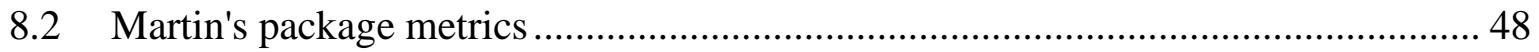

8.3 Chidamber and Kemerer class metrics ............................................................. 49

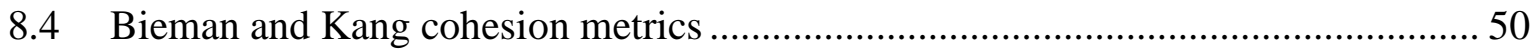

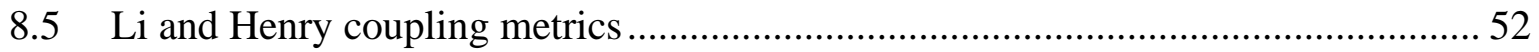

8.6 Briand, Devanbu, and Melo coupling metrics................................................ 52

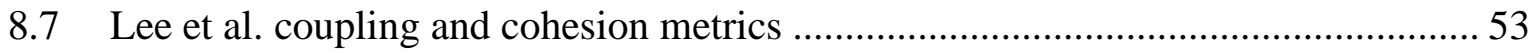

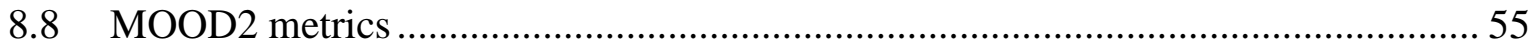

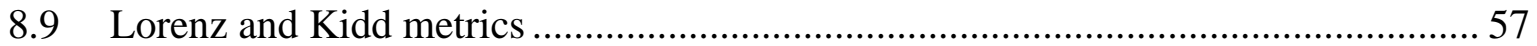

9 Testability (test coverage) metrics................................................................................6 60

9.1 Rapps, Frankl, and Weyuker data flow coverage metrics .................................... 60

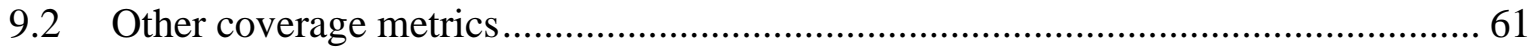

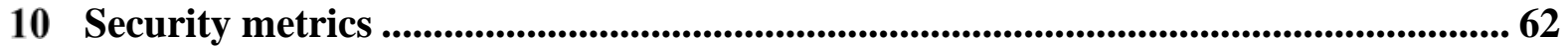

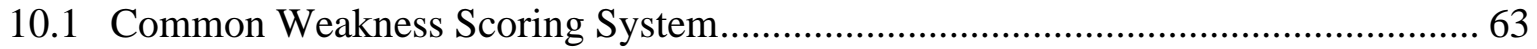

10.2 Common Vulnerability Scoring System.............................................................. 66

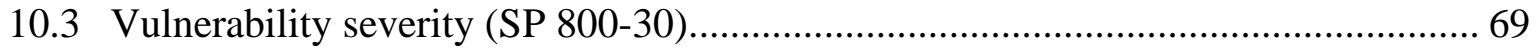

11 Bibliography ................................................................................................................ 70

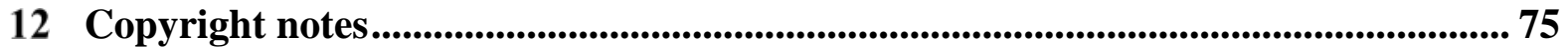




\section{Measurement concepts}

\section{$0.1 \quad$ Normative references}

The following referenced documents are taken to be canonical for the established system of metrology:

- "The SI Brochure:" International Bureau of Weights and Measures (Bureau International des Poids et Mesures, BIPM). The International System of Units (Le Système international d'unités, SI), 9th edition, 2019. http://www.bipm.org/en/publications/si-brochure/

- "The VIM:" Joint Committee for Guides in Metrology (JCGM). International vocabulary of metrology (Vocabulaire international de métrologie, VIM)-Basic and general concepts and associated terms, 3rd edition. JCGM 200:2012. http://www.bipm.org/en/publications/guides/vim.html

- "The GUM:" Joint Committee for Guides in Metrology. Evaluation of measurement data-Guide to the expression of uncertainty in measurement (GUM). JCGM 100:2008.

http://www.bipm.org/utils/common/documents/jcgm/JCGM 1002008 E.pdf

- "The International System of Quantities (ISQ):" International Organization for Standardization (ISO) / International Electrotechnical Commission (IEC) 80000, Quantities and units.

\section{$0.2 \quad$ Basic terms}

The following terms are defined by the 3rd edition of the VIM [VIM]:

quantity: property of a phenomenon, body, or substance, where the property has a magnitude that can be expressed as a number and a reference.

[The "reference" is typically an expression in terms of SI units.]

quantity value: number and reference together expressing magnitude of a quantity. Example 1: Length of a given rod: $5.34 \mathrm{~m}$ or $534 \mathrm{~cm}$.

measured quantity value: quantity value representing a measurement result.

measurement result: set of quantity values being attributed to a measurand together with any other available relevant information.

[The "set of quantity values" is intended to accommodate uncertainty, given that a single true quantity value generally cannot be determined.] 
In common software jargon (and thus, within this document), the term "metric" is used in a broad manner to include not just measurable quantities in the strict sense but calculated values and assigned classifications of any sort that are treated as measurement results. Similarly, "measure" used as a noun can mean measurement (as in the idiomatic "unit of measure"), metric, or unit (as in "measure of X"), depending on context.

\section{$0.3 \quad$ Extended units}

A quantity in the SI can be stated as a mathematical expression-the product of a numerical value and a unit of measurement. The magnitude of a quantity can be expressed in terms of the seven $\mathrm{SI}$ traditional base quantities length $(\mathrm{m})$, mass $(\mathrm{kg})$, time $(\mathrm{s})$, electric current $(\mathrm{A})$, thermodynamic temperature (K), amount of substance (mol), and luminous intensity (cd), either individually or in combinations. These quantities correspond to physical dimensions as used in dimensional analysis.

However, many kinds of quantities have no extent in any of the seven standard dimensions. For example, a counted quantity is a number of some distinguishable kind of thing, such as 32 bits. Unfortunately for computer science, "amount of data" is not an SI dimension, and bits and bytes are not SI units. Ratios of two quantities of the same kind, such as mass fractions $(\mathrm{kg} / \mathrm{kg})$, are a similar major category of quantities. The SI Brochure regards both of these categories of quantities as dimensionless.

In the $\mathrm{SI}$, the unit of measurement for dimensionless quantities is the special unit one. Depending on context, it may be regarded as the derived unit that algebraically results from setting the exponents on all seven of the SI traditional base quantities to zero, or it may instead be regarded as a further base unit that is common to all measurement systems [VIM, $\mathrm{SI}$ ]. A suggestion that it would be clearer to refer to dimension number, with $\mathrm{Z}$ as its symbol and 1 as its coherent unit of measurement [Krystek], has become popular.

To avoid user surprise at the canonical SI treatment of amounts of data and other dimensionless quantities, software libraries and packages that implement quantities and units functions often apply workarounds such as adding an explicit base unit for 1, adding many non-SI dimensions, and allowing users to introduce arbitrary irreducible units (effective extra dimensions). Different software has applied different workarounds, creating subtle problems for transfer of scientific data.

In this document, we follow a model that extends the interpretation of dimensionless quantities by subtyping the special unit one with "extended units." For a complete discussion of this model, related work, and alternative approaches, please see Ref. [Flater].

\section{4 "Amount of data" as a dimension}

For most counted quantities, there is only one obvious unit to use (the counted entity or event), and the question of dimension is obviated by the type system for dimensionless quantities that was mentioned above. However, the coexistence of multiple "natural units" 
of data (bits, bytes, and occasionally words) means that often it is less misleading to cite dimension data than to specify any such unit.

In physical metrology, the National Institute of Standards and Technology (NIST) has proposed that angle be included as an SI dimension with the radian as its coherent unit of measure and the cycle as a non-coherent unit that is equal to $2 \pi$ radians. In parallel fashion, we sometimes find it convenient to think of data as an added dimension with the bit as its coherent unit of measure and the byte as a non-coherent unit that is equal to 8 bits. The fact that amounts of data are counted quantities that cannot be subdivided indefinitely is not always an important factor; the same is true of amounts of substance in the SI.

Stating that a quantity has the dimension of data, rather than the units of bits or bytes, makes it clear that the choice of unit is not an essential part of the definition of the quantity. One can use other counting units, such as data structures of a particular type that can be reduced to a count of bits, without losing traceability.

Dimensions that proved useful in describing software quantities are provided in Sec. 3. They are: time, data, information, and work. Other "effective" dimensions corresponding to the many kinds of nonphysical quantities that are described in this document can easily be posited; however, in most cases, there is nothing to be gained by doing so. The units and/or scale of the result provide complete information.

\subsection{Traceability}

[SI, Sec. 2.3.3] states that counts are traceable to the SI via the special unit one and "appropriate, validated measurement procedures." However, in general, counting involves characterizing what is being counted (say, lines of code), and this characterization involves a standard (definition of line of code) that is not part of the SI. Therefore, the task of defining most extended units falls on the downstream users of the SI.

Traceability is complicated further when some kind of count is used as a surrogate measure of another kind of quantity. For example, the durations of some software processes may be expressed in Central Processing Unit (CPU) cycles rather than in seconds. A given number of CPU cycles translates to a variable number of seconds because the CPU frequency varies. Analogously, a program may transfer a fixed number of data entities of a given type, but if these entities vary in size, then the number of bits transferred will vary.

Practitioners may find it expedient to use the non-traceable units because the resulting expression apparently is more precise. However, sacrificing traceability means that the actual duration of the process (in seconds) or the actual amount of data transferred (in bits) has not been quantified. A process that took more CPU cycles to run may actually have taken less time. This may or may not be an important consideration, depending on the use of the measured quantity values, but it is anathema to theories of measurement that seek to relate all quantities to real, independent, objective properties. 


\subsection{Scales}

Scale theory is a small part of the broad discipline of measurement theory. It was popularized in 1946 by Stanley S. Stevens [Stevens] and subsequently extended, formalized, reinterpreted, and criticized by many others.

The following scales suffice for the purposes of this document. N.B., These traditional scale definitions are incompatible with the formal definitions used in [Zuse].

- A dichotomic scale has only two values, typically named yes/no or true/false, which have no particular ordering (thus "scale" is a misnomer).

- Nominal is the "scale" of measurements that assign identifiers that have no particular ordering. A "nominal set," in which the identifiers are not mutually exclusive, is reducible to a set of independent dichotomic measures.

- Ordinal is the scale of measurements that assign numbers in a fashion that preserves relative ordering but nothing more. There is no unit of measurement for results on an ordinal scale because the magnitudes have no meaning beyond relative ordering.

- Interval is the scale of measurements that have a meaningful unit but not a meaningful zero point. For example, temperature can be measured on either the Celsius or Fahrenheit scales, but their zero points are different and do not correspond to a physical minimum.

- Ratio is the scale on which physical measurements of length, mass, time, etc. are made. Since they have a meaningful zero point, quantities on a ratio scale can be transformed by a simple multiplicative scaling factor without losing information; e.g., $5 \mathrm{~m}$ is the same quantity as $500 \mathrm{~cm}$.

In this document, a derived number for which no unit or representational structure is obvious is deemed ordinal, even though the metric may not even preserve a relative ordering by the measurand. When a unit is derivable but not consistent with how the metric is used, the scale may also be deemed ordinal.

\section{Guide to the system}

\subsection{Scope, goals, and non-goals}

The word "software" covers a lot of territory, either directly or indirectly. A notional software attribute can be different things depending on which artifact or process serves as the object of measurement. Our objects of measurement include the following:

- Architecture, design

- Requirements

- Specification

- Algorithm

- Implementation (source code or script) 
- Executable (binary or bytecode)

- Execution (of binary, bytecode, or script)

The purpose of this document is to provide a systematic reference for metrics that are in use. Non-goals of this document include:

- Providing a tutorial on computer science, software measurement, or metrology;

- Creating another self-consistent vocabulary for computer science, software measurement, or metrology, to compete with [ISO-Vocab], [VIM], and similar standards;

- Creating a complete catalog of every software metric that was ever used;

- Explaining the use or usefulness of individual metrics;

- Evaluating the meaningfulness, validity, or formal properties of individual metrics;

- Explaining or mitigating the deficiencies of individual metrics beyond what is necessary to integrate them into the system without confusing the reader;

- $\quad$ "Picking winners" among competing candidates for metrics of a given type.

We prioritize practical usability over rigid consistency and eschew organizing principles that would require commonly associated metrics to be separated from one another in the document.

\subsection{Criteria for inclusion}

The determination of which metrics to include was made according to the following criteria:

1. Species: the ostensible metric must actually be a metric and not merely a framework, model, methodology, method, architecture, paradigm, foundation, or theory.

2. Scope: the metric must apply to a software artifact, i.e., one of the objects listed in Sec. 1.1, and it must measure some objective property. Metrics that resemble customer satisfaction surveys are excluded. Edge case: the security metrics in Ch. 10.

3. Clarity: the metric and its result must not depend on models or concepts that are too abstruse to summarize reasonably in this document.

4. Completeness: the metric must not depend on made-up numbers (e.g., arbitrary weighting factors, typically denoted by $\mathrm{w}_{\mathrm{i}}$ ), unspecified threshold values, or quantities for which no reliable measurement method is known (e.g., number of incorrect requirements, total number of possible use cases). Edge case: the combinatorial coverage metrics in Sec. 9.2 depend on the selection of a finite set of valid values for variables.

5. Notability: there must exist references to the metric by sources other than the originating author or organization. Large, complicated metrics that are difficult to incorporate need correspondingly stronger evidence of notability. Edge case: some obscure metrics have been referenced in surveys that are more notable and available than the original sources. Such references beget more references in later surveys 
even if the metrics never had any practical application, as each survey aims for completeness.

6. Availability: the definition of the metric must be published and obtainable with a web search or an interlibrary loan, or it must appear in an international standard. Edge case: [DO-178C] is an important reference but is not widely published.

7. Not a hardware reliability metric: generic systems reliability metrics like mean time to failure (MTTF) that sometimes are applied to software are adequately covered by other standards. A sample of such measures is provided in Institute of Electrical and Electronics Engineers (IEEE) 982.1, IEEE Standard Dictionary of Measures of the Software Aspects of Dependability (2005).

8. Not a checklist or laundry list: the metric must not depend on a list of disparate rules or factors that would be unreasonable to quote in its entirety in this document.

9. Not overspecialized: to avoid an infinite proliferation of variations on a theme, a metric that is an obvious specialization or derivative of something already included here, need not be included here. For example, given that number of operations is included, we do not necessarily need entries for the number of illegal operations for every possible definition of illegal, the mean number of operations per every possible denominator, or the proportion of operations that are legal, unless the derivative forms are especially notable in themselves.

The metrological validity and soundness of metrics was not evaluated. The inclusion of a metric is not a recommendation or endorsement, and the exclusion of a metric is not a criticism or condemnation.

\subsection{Guide to tables}

Ch. 2 and later chapters detail the software system of quantities in a series of tables. The columns of those tables are explained below.

- The Names column gives the intelligible short description or alternative descriptions of the quantity.

- The Symbols column attempts to provide either the canonical symbol assigned by a primary reference or the symbols that are most commonly used in practice to identify a quantity. This document makes no attempt to catalog every symbol ever used for a given quantity; the proliferation is too great and is not to be encouraged.

- The Definitions column defines the quantity and includes any necessary discussion. In especially complex cases, a summary is given and readers must consult the cited references for the complete definition. References to input quantities that are defined elsewhere in the document may be indicated by bold font. Superscript numbers refer to the copyright notes listed in Ch. 12.

- The References column contains one or more of the following: 
- Supertypes: the References column of the tables in Ch. 2 identifies the immediate supertypes of dimensionless units within a type system as described in [Flater].

- Unit: an expression in terms of the counting units of Ch. 2 and SI units as applicable. For ratios of two quantities of the same kind, such as compression ratio, the units are shown in unsimplified form (bit/bit) for clarity.

- Dimension: when specific units are over-constraining, an expression in terms of the dimensions of Ch. 3 and SI dimensions may be given instead.

- Scale: if a unit or dimension was specified, a ratio scale is implied; otherwise, an interval, ordinal, nominal, or dichotomic scale is specified.

- Range: further explanation of the meaning of the output values, when needed.

- Reference: the source of the definition or the document to refer to for details of the measurement method. In the absence of quotation marks, the definition may be a paraphrase, summary, reduction, or rewrite of some portion of the cited source. The source may provide multiple definitions of which only one was selected. When no reference is given, the definition is a best effort to fill gaps in the canon.

Tables at the beginning of a section that are introduced as "model" or "defined inputs" provide definitions that the quantities in a subsequent table depend on. These inputs are not necessarily quantities, but may be sets or other abstractions that have neither units nor scale. The information provided is a subset of what was described above.

\subsection{History and future}

This document was started in 2017 by Sumaiyah Sarwat for a Summer Undergraduate Research Fellowship (SURF) with David Flater as research advisor. It was finished by David Flater and submitted to the International Electrotechnical Commission (IEC) in 2018 as initial basis for new work item proposal PNW 25-631 to create 80000-18, Quantities and unitsPart 18: Software product. It received the necessary $2 / 3$ majority of votes for approval, but only 3 of the approving members nominated experts to participate in development. A minimum of 4 experts from approving members was required, so the new work item proposal ultimately was rejected. Subsequently, the document was made a NIST publication with copyright clearance assistance by Karen Reczek and technical reviews by Paul E. Black and David B. Newell.

In current practice, many of the elementary quantities of software measurement are multiply-defined and/or ill-defined. Improving and standardizing the definitions of these base quantities is within the traditional scope of international standards work. As software metrology becomes a mature discipline, the document should become less descriptive (following the practice) and more prescriptive (normative). This transition requires consensus, and the proper venue for such a consensus to emerge is international standards. 


\section{Countable entities and events}

In the following tables, entity and event serve as the most general counting units at the top of the type system (disregarding unit one), following the pattern that was initiated in [Mohr].

Metrology practice maintains a clear distinction between symbols that denote quantities, such as / denoting length, and symbols that denote units, such as $m$ denoting the meter (the unit of length). To express that a length is 5 meters, one would write $l=5 \mathrm{~m}$ but not $\mathrm{m}=5$. In contrast, the usage of symbols in software practice often is equivocal over whether a symbol refers to a counted quantity (e.g., $L O C=5$ ) or a type of entity that is used as a counting unit (5 LOC). In such cases, the counted quantity can be described simply as "Number of [countable entity]," and a definition of the countable entity would be sufficient to define the quantity. Indeed, many software metrics are nothing more than these counts, embellished by description. For example, the number of LOC, the number of classes, or the number of terms could all be described, in some fashion, as the "size" (more accurately, a size) of a software artifact. However, certain symbols, such as Halstead's $N_{1}$ and $\eta_{1}$, qualify the method of counting so that merely cataloging the countable entity types is insufficient.

Many higher-level, derived software metrics define input quantities in-line with expressions like "...where $N$ is the number of (...)." In a more mature system of quantities, commonlyused counts might have standard symbols, and $\mathrm{n}$ and $\mathrm{N}$ might not be so overloaded.

\subsection{Elementary entities}

\begin{tabular}{|l|l|l|l|}
\hline Names & Symbols & Definitions & References \\
\hline Bit & b & $\begin{array}{l}\text { Quantum unit of data. } \\
\text { The definition of 'b' as the symbol for bit was made } \\
\text { in [IEEE-100] (now withdrawn), and thence } \\
\text { indirectly by [IEEE-1541] which makes normative } \\
\text { reference to it, but [IEC] does not use it. In } \\
\text { practice, it appears widely as bandwidths are quoted } \\
\text { in units of "Mbps" (meaning Mb/s) or "Gbps" } \\
\text { (meaning Gb/s). } \\
\text { The 'b' symbol is also used for the barn, a non-SI } \\
\text { unit of area. }\end{array}$ & \\
\hline $\begin{array}{l}\text { Qubit } \\
\text { Quantum bit }\end{array}$ & $\begin{array}{l}\text { Bit, in the context of quantum computing. } \\
\text { [IEE }\end{array}$ & $\begin{array}{l}\text { Bit } \\
\text { [Schumacher] }\end{array}$ \\
\hline
\end{tabular}




\begin{tabular}{|c|c|c|c|}
\hline Names & Symbols & Definitions & References \\
\hline Byte & B & $\begin{array}{l}\text { = } 8 \text { bit } \\
\text { In many contexts, the byte is practically used as the } \\
\text { quantum unit of data because individual bits cannot } \\
\text { be directly addressed. } \\
\text { The derived unit byte, symbol B, has de facto been } \\
\text { standardized as } 8 \text { bits, but may vary in historical } \\
\text { uses. [IEC] suggests the less ambiguous unit octet, } \\
\text { symbol o, but this is seldom seen in practice. } \\
\text { The 'B' symbol is also used for the bel, a non-SI } \\
\text { unit of logarithmic ratio quantities. }\end{array}$ & [IEC] \\
\hline Word & & $\begin{array}{l}\text { "The normal unit in which information may be } \\
\text { stored, transmitted, or operated on within a given } \\
\text { computer." }{ }^{10} \text { Like the byte, the word is defined as a } \\
\text { number of bits, but the number is architecture- } \\
\text { dependent. }\end{array}$ & [IEEE-100] \\
\hline Character & char & $\begin{array}{l}\text { "A sequence of one or more bytes representing a } \\
\text { single graphic symbol." } 10 \text { The number of bytes per } \\
\text { symbol may vary, as it does in the popular encoding } \\
\text { UTF-8 (8-bit Unicode Transformation Format). }\end{array}$ & $\begin{array}{l}\text { Entity } \\
\text { [IEEE-100] } \\
\text { [Fenton, p. } \\
\text { 346] }\end{array}$ \\
\hline Pixel & $\mathrm{px}$ & $\begin{array}{l}\text { Etymologically derived from picture element, pixels } \\
\text { are the elementary constituents of raster graphics } \\
\text { images. }\end{array}$ & Entity \\
\hline $\begin{array}{l}\text { Instruction, } \\
\text { Operation }\end{array}$ & op & $\begin{array}{l}\text { Unit of machine code / assembly language. } \\
\text { Depending on the implementation, instructions may } \\
\text { be indivisible or they may translate into blocks of } \\
\text { microcode. }\end{array}$ & Entity \\
\hline $\begin{array}{l}\text { Microinstruction, } \\
\text { Micro-operation }\end{array}$ & $\mu о p$ & $\begin{array}{l}\text { Quantum unit of microcode. (Caution: while the } \\
\text { name and symbol imply that } 1 \text { op }=10^{6} \mu \text { op, } \\
\text { instructions and microinstructions are not actually } \\
\text { comparable. The use of the micro- prefix here, } \\
\text { established in software jargon, is misleading and } \\
\text { incompatible with the SI.) }\end{array}$ & Entity \\
\hline
\end{tabular}

\subsection{Source-level entities}

Many of the entities given in this section have problematic definitions. Some have standard definitions that conflict with their meanings within widely-used software metrics, and some have no standard definitions at all. As was mentioned in Sec. 1.4, gaining consensus on an adequate set of definitions for these base quantities is a work item for the standardization of software metrology. 


\begin{tabular}{|c|c|c|c|}
\hline Names & Symbols & Definitions & References \\
\hline $\begin{array}{l}\text { Line of code, } \\
\text { Source line of } \\
\text { code, } \\
\text { Physical line of } \\
\text { code }\end{array}$ & $\begin{array}{l}\text { LOC, } \\
\text { SLOC }\end{array}$ & $\begin{array}{l}\text { Segment of source code that is delimited by the } \\
\text { applicable end-of-line string (usually a single line } \\
\text { feed character or a carriage return-line feed } \\
\text { combination) or by the beginning or end of the file. } \\
\text { See [Park] for a framework of many different yet } \\
\text { equally plausible definitions of this quantity. [Misa] } \\
\text { defines SLOC as LOC minus blank lines and } \\
\text { comment lines (= NCLOC, see below). }\end{array}$ & $\begin{array}{l}\text { Entity } \\
{[\text { Park }]}\end{array}$ \\
\hline $\begin{array}{l}\text { Logical line of } \\
\text { code }\end{array}$ & LLOC & $\begin{array}{l}\text { Ambiguous. Possible meanings include: } \\
\text { 1. NCLOC } \\
\text { 2. LOC after concatenating continuation lines } \\
\text { 3. NCLOC after concatenating continuation lines } \\
\text { 4. Statement }\end{array}$ & $\begin{array}{l}\text { Entity (not } \\
\text { necessarily } \\
\text { LOC) }\end{array}$ \\
\hline $\begin{array}{l}\text { Comment line } \\
\text { of code }\end{array}$ & CLOC & $\begin{array}{l}\text { LOC containing nothing but comments and } \\
\text { whitespace, or that is completely empty (blank). }\end{array}$ & $\begin{array}{l}\text { LOC } \\
\text { [Fenton, pp. } \\
340-341]\end{array}$ \\
\hline $\begin{array}{l}\text { Noncommented } \\
\text { line of code, } \\
\text { Effective line } \\
\text { of code }\end{array}$ & NCLOC & $\begin{array}{l}\text { LOC that is not a CLOC. } \\
\text { LOC }=\text { NCLOC + CLOC }\end{array}$ & $\begin{array}{l}\text { LOC } \\
\text { [Fenton, pp. } \\
\text { 340-341] }\end{array}$ \\
\hline $\begin{array}{l}\text { Line of } \\
\text { comments }\end{array}$ & $\begin{array}{l}\text { CM, } \\
\text { CMT }\end{array}$ & $\begin{array}{l}\text { LOC that contains a comment (and possibly other } \\
\text { content); "a physical line on which there is a } \\
\text { comment." This usage seems rare but is referenced in } \\
\text { Sec. 7.12. }\end{array}$ & $\begin{array}{l}\text { LOC } \\
\text { [Welker, p. } \\
\text { 130] }\end{array}$ \\
\hline $\begin{array}{l}\text { Function, } \\
\text { Procedure, } \\
\text { Subroutine, } \\
\text { Submodule }\end{array}$ & & $\begin{array}{l}\text { "Portion of a computer program that is named and } \\
\text { that performs a specific action." } 6 \\
\text { This concrete source code entity should not be } \\
\text { confused with the abstract unit of functionality } \\
\text { function appearing in Sec. } 2.6 \text {. }\end{array}$ & $\begin{array}{l}\text { Entity } \\
\text { [ISO-Vocab] }\end{array}$ \\
\hline Module & & $\begin{array}{l}\text { "Program unit that is discrete and identifiable with } \\
\text { respect to compiling, combining with other units, and } \\
\text { loading." } \\
\text { "Collection of both data and the routines that act on } \\
\text { it." }{ }^{6}\end{array}$ & $\begin{array}{l}\text { Entity } \\
\text { [ISO-Vocab] }\end{array}$ \\
\hline Class & & $\begin{array}{l}\text { "Static programming entity in an object-oriented } \\
\text { program that contains a combination of functionality } \\
\text { and data." } 6 \\
\text { Sometimes compared to a module unit of procedural } \\
\text { programming (for larger interpretations of module). }\end{array}$ & $\begin{array}{l}\text { Entity } \\
\text { [ISO-Vocab] }\end{array}$ \\
\hline
\end{tabular}




\begin{tabular}{|c|c|c|c|}
\hline Names & Symbols & Definitions & References \\
\hline $\begin{array}{l}\text { Package, } \\
\text { Subsystem, } \\
\text { Cluster }\end{array}$ & & $\begin{array}{l}\text { "Separately compilable software component } \\
\text { consisting of related data types, data objects, and } \\
\text { subprograms." } \\
\text { In object-oriented contexts, a package consists of } \\
\text { related classes. } \\
\text { "A subsystem is a collection of classes that support a } \\
\text { set of end-user functions." }\end{array}$ & $\begin{array}{l}\text { Entity } \\
\text { [ISO-Vocab, } \\
\text { Lorenz] }\end{array}$ \\
\hline Data type & & "Set of values and operations on those values." ${ }^{6}$ & $\begin{array}{l}\text { Entity } \\
\text { [ISO-Vocab] }\end{array}$ \\
\hline $\begin{array}{l}\text { Abstract data } \\
\text { type }\end{array}$ & ADT & $\begin{array}{l}\text { "Data type for which only the properties of the data } \\
\text { and the operations to be performed on the data are } \\
\text { specified, without concern for how the data will be } \\
\text { represented or how the operations will be } \\
\text { implemented." }{ }^{6} \text { Sometimes synonymous with class. }\end{array}$ & $\begin{array}{l}\text { Data type } \\
\text { [ISO-Vocab] }\end{array}$ \\
\hline Block & & $\begin{array}{l}\text { Group of contiguous statements that are treated as a } \\
\text { unit. }{ }^{6}\end{array}$ & $\begin{array}{l}\text { Entity } \\
\text { [ISO-Vocab] }\end{array}$ \\
\hline $\begin{array}{l}\text { Method, } \\
\text { Operation }\end{array}$ & & $\begin{array}{l}\text { Source code unit from object-oriented programming; } \\
\text { a function that is scoped by and contained within a } \\
\text { class. } \\
\text { "Operation" is the term used in [UML], but in this } \\
\text { document it is too easily confused with its other } \\
\text { definitions, so herein we prefer "method." }\end{array}$ & Function \\
\hline Statement & & $\begin{array}{l}\text { "In a programming language, a meaningful expression } \\
\text { that defines data, specifies program actions, or directs } \\
\text { the assembler or compiler." }{ }^{6} \text { (The term "expression" } \\
\text { is used in a more general sense in the preceding quote } \\
\text { than the way it is defined below.) } \\
\text { A unit corresponding to a single "command." }\end{array}$ & $\begin{array}{l}\text { Entity } \\
\text { [ISO-Vocab] }\end{array}$ \\
\hline Expression & & $\begin{array}{l}\text { "Sequence of constants, variables, and functions } \\
\text { connected by operators to indicate a desired } \\
\text { computation." } 10\end{array}$ & $\begin{array}{l}\text { Entity } \\
\text { [IEEE-100] }\end{array}$ \\
\hline $\begin{array}{l}\text { Data object, } \\
\text { Data element, } \\
\text { Data item }\end{array}$ & & Entity that occupies storage or consumes bandwidth. & Entity \\
\hline Variable & & "Quantity or data item whose value can change." ${ }^{6}$ & $\begin{array}{l}\text { Data object } \\
\text { [ISO-Vocab] }\end{array}$ \\
\hline $\begin{array}{l}\text { Parameter, } \\
\text { Argument, } \\
\text { In-parameter }\end{array}$ & & $\begin{array}{l}\text { An input to a function or procedure. } \\
\text { In many contexts it is necessary to distinguish the } \\
\text { declared "formal parameter" from the "actual } \\
\text { parameter" provided at invocation. }\end{array}$ & $\begin{array}{l}\text { Operand, } \\
\text { Data object }\end{array}$ \\
\hline $\begin{array}{l}\text { Result, } \\
\text { Return value, } \\
\text { Out-parameter }\end{array}$ & & An output of a function or procedure. & $\begin{array}{l}\text { Operand, } \\
\text { Data object }\end{array}$ \\
\hline
\end{tabular}




\begin{tabular}{|c|c|c|c|}
\hline Names & Symbols & Definitions & References \\
\hline Operand & & $\begin{array}{l}\text { "Variable, constant, or function upon which an } \\
\text { operation is to be performed." } 6 \\
\text { A parameter or result.* }\end{array}$ & $\begin{array}{l}\text { Term } \\
\text { [ISO-Vocab] } \\
\text { [Halstead] }\end{array}$ \\
\hline $\begin{array}{l}\text { Call, } \\
\text { Invocation, } \\
\text { Operation, } \\
\text { Message send }\end{array}$ & & $\begin{array}{l}\text { Source code entity that causes a call/invocation event } \\
\text { (see profiling units). An operator together with its } \\
\text { operands. }\end{array}$ & Entity \\
\hline Exception & & $\begin{array}{l}\text { Source code entity that represents or describes an } \\
\text { exception (event). }\end{array}$ & Entity \\
\hline Operator & & $\begin{array}{l}\text { "Mathematical or logical symbol that represents an } \\
\text { action to be performed in an operation." } 6 \\
\text { 1. Narrowly: the predefined programming language } \\
\text { functions that include mathematical, logical, } \\
\text { grouping, indexing, dereferencing, address-of, } \\
\text { scoping, character string, etc. functions. } \\
\text { 2. More broadly: any function or procedure that has } \\
\text { one or more operands. } \\
\text { 3. [Halstead] also considers control constructs to be } \\
\text { operators [Halstead p. 7]. See mises en pratique.* }\end{array}$ & $\begin{array}{l}\text { Term } \\
\text { [ISO-Vocab] } \\
\text { [Halstead] }\end{array}$ \\
\hline Token & & $\begin{array}{l}\text { Operator or operand.* (This generalization is the } \\
\text { unit of several of Halstead's metrics, but is not given a } \\
\text { name in [Halstead].) }\end{array}$ & $\begin{array}{l}\text { Entity } \\
\text { [Halstead] }\end{array}$ \\
\hline Site & & $\begin{array}{l}\text { Source code entity that indicates where a weakness } \\
\text { may exist or does exist, i.e., a code location with } \\
\text { characteristics relevant to bug classes. "A location in } \\
\text { code where a weakness might occur." }\end{array}$ & $\begin{array}{l}\text { Entity } \\
\text { [IR8113] }\end{array}$ \\
\hline $\begin{array}{l}\text { Branch, } \\
\text { Decision-to- } \\
\text { decision path }\end{array}$ & DD-path & $\begin{array}{l}\text { One of the outbound paths from a conditional } \\
\text { statement; e.g., an if-then-else conditional has two } \\
\text { branches, one of which is executed if the expression is } \\
\text { true and the other of which is executed if the } \\
\text { expression is false. }\end{array}$ & $\begin{array}{l}\text { Entity } \\
\text { [ISO-Vocab] }\end{array}$ \\
\hline Condition & & $\begin{array}{l}\text { "A Boolean expression containing no Boolean } \\
\text { operators except for the unary operator (NOT)." } 11\end{array}$ & $\begin{array}{l}\text { Expression } \\
\text { [DO-178C] }\end{array}$ \\
\hline Decision & & $\begin{array}{l}\text { "A Boolean expression composed of conditions and } \\
\text { zero or more Boolean operators. If a condition } \\
\text { appears more than once in a decision, each occurrence } \\
\text { is a distinct condition." } 11\end{array}$ & $\begin{array}{l}\text { Expression } \\
\text { [DO-178C] }\end{array}$ \\
\hline $\begin{array}{l}\text { Entry point, } \\
\text { Entry }\end{array}$ & & $\begin{array}{l}\text { "Point in a software module at which execution of the } \\
\text { module can begin." } 6\end{array}$ & $\begin{array}{l}\text { Statement } \\
\text { [ISO-Vocab] }\end{array}$ \\
\hline $\begin{array}{l}\text { Exit point, } \\
\text { Exit }\end{array}$ & & $\begin{array}{l}\text { "Point in a software module at which execution of the } \\
\text { module can terminate." } 6\end{array}$ & $\begin{array}{l}\text { Statement } \\
\text { [ISO-Vocab] }\end{array}$ \\
\hline $\begin{array}{l}\text { Data flow, } \\
\text { Information } \\
\text { flow }\end{array}$ & & $\begin{array}{l}\text { Transfer of data from one module to another. (Note } \\
\text { that this refers to the implementation of such transfer } \\
\text { in software, not the event of it occurring at run time.) }\end{array}$ & $\begin{array}{l}\text { Entity } \\
\text { [Henry] }\end{array}$ \\
\hline
\end{tabular}


* Halstead's model that "an algorithm consists of operators and operands, and of nothing else" [Halstead p. 8] is difficult to reconcile with complex programming languages that implement various declarations, control constructs, pragmas, etc. "The counting rules for the basic metrics are ill-defined, arbitrary and not applicable to languages with structured and abstract data types" [Hamer]. Halstead's counting units consequently get defined through unofficial "mises en pratique"-third-party documents that specify how to count them (or how they are counted in fact by some tool, for better or worse) for specific programming languages.

\subsection{Graph entities}

"The material which follows comes mostly from a larger area of mathematics known as the theory of graphs. Unfortunately, there is as yet no standard terminology in this field, and so the author has followed the usual practice of contemporary books on graph theory, namely to use words that are similar but not identical to the terms used in any other books on graph theory." [Knuth, Sec. 2.3.4]

Software metrology depends on graph theory due to the common use of control flow graphs, data flow graphs, dependency graphs, and other graphs in software measurement.

It is apparently the case that graph-theoretic terms such as walk, trail, circuit, path, chain, and cycle have not been standardized and are used differently in different sources. See Mathematics Stack Exchange, "What is difference between cycle, path and circuit in Graph Theory" and similar discussions. The impacted definitions below are tagged with the following attributes, which act as constraints:

$\mathrm{N}=$ reuse of nodes is prohibited (except special case for initial-final node in a cycle)

$\mathrm{E}=$ reuse of edges is prohibited

$\mathrm{D}=$ direction of arcs matters

$\mathrm{C}=$ closed; end of sequence is required to be the same as the beginning.

\begin{tabular}{|l|l|l|l|}
\hline Names & Symbols & Definitions & References \\
\hline $\begin{array}{l}\text { Edge, } \\
\text { Arc }\end{array}$ & $\begin{array}{l}\text { e [McCabe], } \\
\text { m [Berge] }\end{array}$ & A line or arrow in a graph. & $\begin{array}{l}\text { Entity } \\
\text { [Berge] }\end{array}$ \\
\hline $\begin{array}{l}\text { Node, } \\
\text { Vertex }\end{array}$ & $\begin{array}{l}\text { n [Berge, } \\
\text { McCabe] }\end{array}$ & A point in a graph. & $\begin{array}{l}\text { Entity } \\
\text { [Berge] }\end{array}$ \\
\hline $\begin{array}{l}\text { Predicate } \\
\text { node }\end{array}$ & $\begin{array}{l}\pi \text { [McCabe], } \\
\mathrm{d} \text { [Fenton] }\end{array}$ & $\begin{array}{l}\text { Flowgraph node with out-degree greater than 1. } \\
\text { Using the symbol } \pi \text { for the count of predicate nodes } \\
\text { conflicts with its canonical interpretation as a } \\
\text { mathematical constant. }\end{array}$ & $\begin{array}{l}\text { Node } \\
\text { [McCabe] }\end{array}$ \\
\hline $\begin{array}{l}\text { Connected } \\
\text { component }\end{array}$ & $\begin{array}{l}\mathrm{p} \text { [Berge, } \\
\text { McCabe] }\end{array}$ & $\begin{array}{l}\text { A class of the equivalence relation }[\mathrm{x}=\mathrm{y}, \text { or } \mathrm{x} \neq \mathrm{y} \text { and } \\
\text { there exists a chain in } \mathrm{G} \text { connecting } \mathrm{x} \text { and } \mathrm{y}] .\end{array}$ & $\begin{array}{l}\text { Entity } \\
\text { [Berge] }\end{array}$ \\
\hline
\end{tabular}




\begin{tabular}{|l|l|l|l|}
\hline Names & Symbols & Definitions & References \\
\hline Chain & $\begin{array}{l}\text { "A sequence } \mu=\left(\mathrm{u}_{1}, \mathrm{u}_{2}, \ldots, \mathrm{u}_{\mathrm{q}}\right) \text { of arcs of G such } \\
\text { that each arc in the sequence has one endpoint in } \\
\text { common with its predecessor in the sequence and } \\
\text { its other endpoint in common with its successor in } \\
\text { the sequence". }\end{array}$ & $\begin{array}{l}\text { Entity } \\
\text { [Berge] }\end{array}$ \\
\hline $\begin{array}{l}\text { Elementary } \\
\text { chain }\end{array}$ & $\begin{array}{l}\text { "Chain that does not encounter the same vertex } \\
\text { twice." } \mathrm{N}\end{array}$ & $\begin{array}{l}\text { Chain } \\
\text { [Berge] }\end{array}$ \\
\hline Simple chain & "Chain that does not use the same arc twice." E & $\begin{array}{l}\text { Chain } \\
\text { [Berge] }\end{array}$ \\
\hline Cycle & $\begin{array}{l}\text { Simple chain whose endpoints are the same } \\
\text { vertex. EC }\end{array}$ & $\begin{array}{l}\text { Simple chain } \\
\text { [Berge] }\end{array}$ \\
\hline $\begin{array}{l}\text { Elementary } \\
\text { cycle }\end{array}$ & $\begin{array}{l}\text { Cycle in which "no vertex is encountered more than } \\
\text { once (except, of course, the initial vertex which is } \\
\text { also the terminal vertex)." NEC } \\
\text { The exception for the initial-final vertex in this } \\
\text { representation of cycles means that elementary } \\
\text { cycle is not a subtype of elementary chain. }\end{array}$ & $\begin{array}{l}\text { Cycle } \\
\text { [Berge] }\end{array}$ \\
\hline Path & $\begin{array}{l}\text { Chain "in which the terminal endpoint of arc } \mathrm{u}_{\mathrm{i}} \text { is } \\
\text { the initial endpoint of arc } \mathrm{u}_{\mathrm{i}+1} \text { for all } \mathrm{i}<\mathrm{q} . " \text { D }\end{array}$ & $\begin{array}{l}\text { Chain } \\
\text { [Berge] }\end{array}$ \\
\hline Circuit & $\begin{array}{l}\text { Cycle "such that for all } \mathrm{i}<\mathrm{q} \text { the terminal endpoint of } \\
\text { uni is the initial endpoint of } \mathrm{u}_{\mathrm{i}+1 . "} \text { EDC }\end{array}$ & $\begin{array}{l}\text { Cycle } \\
\text { [Berge] }\end{array}$ \\
\hline Knot & $\begin{array}{l}\text { Place where two arrows are forced to cross each } \\
\text { other in some prescribed graph layout. }\end{array}$ & $\begin{array}{l}\text { Entity } \\
\text { [Woodward] }\end{array}$ \\
\hline
\end{tabular}

\subsection{Dependency and definition/use entities}

Uses, interactions, and dependencies have to do with relationships among source code entities. As such, they may exist only in a model of the software, or they may be ascribed to one of the involved entities (e.g., the dependency of A on B may be ascribed to $A$ as the point of use). There are several alternative models and vocabularies.

\begin{tabular}{|l|l|l|l|}
\hline Names & Symbols & Definitions & References \\
\hline Definition & def & $\begin{array}{l}\text { Variable occurrence "in which a value is stored } \\
\text { in a memory location." }\end{array}$ & $\begin{array}{l}\text { Entity } \\
\text { [Frankl] }\end{array}$ \\
\hline Use & use & $\begin{array}{l}\text { Variable occurrence "in which a value is } \\
\text { fetched from a memory location." }\end{array}$ & $\begin{array}{l}\text { Entity } \\
\text { [Frankl] }\end{array}$ \\
\hline Computation use & c-use & $\begin{array}{l}\text { Use that "directly affects the computation } \\
\text { being performed or outputs the result of some } \\
\text { earlier definition." }\end{array}$ & $\begin{array}{l}\text { Use } \\
\text { [Frankl] }\end{array}$ \\
\hline Predicate use & p-use & $\begin{array}{l}\text { Use that "directly affects the flow of control } \\
\text { through the subprogram, and thereby may } \\
\text { indirectly affect the computations performed." }\end{array}$ & $\begin{array}{l}\text { Use } \\
\text { [Frankl] }\end{array}$ \\
\hline
\end{tabular}




\begin{tabular}{|c|c|c|c|}
\hline Names & Symbols & Definitions & References \\
\hline $\begin{array}{l}\text { Data declaration- } \\
\text { data declaration } \\
\text { interaction }\end{array}$ & DD-interaction & $\begin{array}{l}\text { "A data declaration } A \text { DD-interacts with } \\
\text { another data declaration } B \text { if a change in } A \text { 's } \\
\text { declaration or use may cause the need for a } \\
\text { change in } B \text { 's declaration or use." }\end{array}$ & $\begin{array}{l}\text { Entity } \\
\text { [Briand93] }\end{array}$ \\
\hline $\begin{array}{l}\text { Data declaration- } \\
\text { subprogram } \\
\text { interaction, } \\
\text { Data declaration- } \\
\text { method } \\
\text { interaction }\end{array}$ & $\begin{array}{l}\text { DS-interaction, } \\
\text { DM-interaction }\end{array}$ & $\begin{array}{l}\text { "A data declaration DS-interacts with a } \\
\text { subprogram if it DD-interacts with at least one } \\
\text { of its data declarations." } \\
\text { "There is a DM-interaction between data } \\
\text { declaration } a \text { and method } m \text {, if } a \text { DD-interacts } \\
\text { with at least one data declaration of } m \text {. Data } \\
\text { declarations of methods include their } \\
\text { parameters, return type and local variables." }\end{array}$ & $\begin{array}{l}\text { CI } \\
\text { [Briand93, } \\
\text { Briand98] }\end{array}$ \\
\hline $\begin{array}{l}\text { Cohesive } \\
\text { interaction }\end{array}$ & CI & $\begin{array}{l}\text { "The set of cohesive interactions in a module is } \\
\text { the union of the sets of DS-interactions and } \\
\text { DD-interactions, with the exception of those } \\
\text { DD-interactions between a data declaration and } \\
\text { a subprogram formal parameter." }\end{array}$ & $\begin{array}{l}\text { Entity } \\
\text { [Briand93] }\end{array}$ \\
\hline Interaction & & $\begin{array}{l}\text { Reference to a class as the type of an attribute, } \\
\text { parameter, or result, or invocation of one of its } \\
\text { methods. }\end{array}$ & $\begin{array}{l}\text { Entity } \\
\text { [Briand97] }\end{array}$ \\
\hline
\end{tabular}

\subsection{Class diagram entities}

\begin{tabular}{|l|l|l|l|}
\hline Names & Symbols & Definitions & References \\
\hline Relationship & $\begin{array}{l}\text { Edge in a class diagram (e.g., association, generalization, } \\
\text { aggregation). }\end{array}$ & $\begin{array}{l}\text { Edge } \\
\text { [UML] }\end{array}$ \\
\hline Attribute & $\begin{array}{l}\text { "Identifiable association between an object and a } \\
\text { value." }^{6}\end{array}$ & $\begin{array}{l}\text { Data object } \\
\text { [ISO-Vocab] }\end{array}$ \\
\hline
\end{tabular}

\subsection{Units of functionality}

Although some shared definitions have been placed in a more general context to avoid duplication, the overlaps between the various standards for functional size measurement (FSM, c.f. Sec. 7.9) have not been fully sorted out.

\begin{tabular}{|l|l|l|l|}
\hline Names & Symbols & Definitions & References \\
\hline $\begin{array}{l}\text { Requirement, } \\
\text { Compliance point }\end{array}$ & $\begin{array}{l}\text { "Condition or capability that must be met or } \\
\text { possessed by" the software "to satisfy an } \\
\text { agreement, standard, specification, or other } \\
\text { formally imposed documents." }\end{array}$ & $\begin{array}{l}\text { Entity } \\
\text { [ISO-Vocab] }\end{array}$ \\
\hline $\begin{array}{l}\text { Use case, } \\
\text { Scenario script }\end{array}$ & $\begin{array}{l}\text { "Sequence of tasks that a system can perform, } \\
\text { interacting with users of the system and } \\
\text { providing a measurable result of value for the } \\
\text { user." } 6\end{array}$ & $\begin{array}{l}\text { Entity } \\
\text { [ISO-Vocab] }\end{array}$ & \\
\hline
\end{tabular}




\begin{tabular}{|c|c|c|c|}
\hline Names & Symbols & Definitions & References \\
\hline Feature & & $\begin{array}{l}\text { "Distinguishing characteristic of a system } \\
\text { item." } 6\end{array}$ & $\begin{array}{l}\text { Entity } \\
\text { [ISO-Vocab] }\end{array}$ \\
\hline Function & & $\begin{array}{l}\text { "Defined objective or characteristic action of a } \\
\text { system or component." }{ }^{6} \\
\text { This abstract unit of functionality should not be } \\
\text { confused with the concrete source code entity } \\
\text { function appearing in Sec. } 2.2 \text {. }\end{array}$ & $\begin{array}{l}\text { Entity } \\
\text { [ISO-Vocab] }\end{array}$ \\
\hline Function point & FP & $\begin{array}{l}\text { Ostensible unit corresponding to a difference of } \\
1 \text { in the result of one of several functional size } \\
\text { measurement methods. However, most of these } \\
\text { methods yield ordinal values. See Sec. 7.9. }\end{array}$ & \\
\hline $\begin{array}{l}\text { IFPUG function } \\
\text { point }\end{array}$ & FP & $\begin{array}{l}\text { "Unit of measure for functional size" } \\
\text { ISO nomenclature: FP (IFPUG-IS) }\end{array}$ & $\begin{array}{l}\text { FP } \\
\text { [ISO-IFPUG] }\end{array}$ \\
\hline $\begin{array}{l}\text { FiSMA function } \\
\text { point }\end{array}$ & Ffp & $\begin{array}{l}\text { FP as resulting from the measurement method } \\
\text { defined in [ISO-FiSMA]. }\end{array}$ & $\begin{array}{l}\text { FP } \\
\text { [ISO-FiSMA] }\end{array}$ \\
\hline $\begin{array}{l}\text { COSMIC } \\
\text { function point }\end{array}$ & CFP & $\begin{array}{l}\text { "The size of one data movement" } \\
\text { FP as resulting from the measurement method } \\
\text { defined in [COSMIC, ISO-COSMIC]. } \\
\text { ISO nomenclature: CFP (ISO/IEC 19761:2011) }\end{array}$ & $\begin{array}{l}\text { FP } \\
\text { [COSMIC, } \\
\text { ISO-COSMIC] }\end{array}$ \\
\hline $\begin{array}{l}\text { MkII function } \\
\text { point }\end{array}$ & MkII FP & $\begin{array}{l}\text { FP as resulting from the measurement method } \\
\text { defined in [ISO-MkII]. } \\
\text { ISO nomenclature: MkII FP (ISO/IEC } \\
\text { 20968:2002) }\end{array}$ & $\begin{array}{l}\text { FP } \\
\text { [ISO-MkII] }\end{array}$ \\
\hline $\begin{array}{l}\text { NESMA function } \\
\text { point }\end{array}$ & FP & $\begin{array}{l}\text { FP as resulting from the measurement method } \\
\text { defined in [ISO-NESMA]. } \\
\text { ISO nomenclature: FP (ISO/IEC 24570:2018) }\end{array}$ & $\begin{array}{l}\text { FP } \\
\text { [ISO-NESMA] }\end{array}$ \\
\hline $\begin{array}{l}\text { Automated } \\
\text { function point }\end{array}$ & AFP & $\begin{array}{l}\text { FP as resulting from the measurement method } \\
\text { defined in [AFP]. }\end{array}$ & $\begin{array}{l}\text { FP } \\
{[\mathrm{AFP}]}\end{array}$ \\
\hline $\begin{array}{l}\text { Base functional } \\
\text { component }\end{array}$ & $\mathrm{BFC}$ & $\begin{array}{l}\text { "Elementary unit of Functional User } \\
\text { Requirements defined by and used by an FSM } \\
\text { Method for measurement purposes" } 1\end{array}$ & $\begin{array}{l}\text { Entity } \\
\text { [ISO-FSM] }\end{array}$ \\
\hline Data function & & $\begin{array}{l}\text { "Functionality provided to the user to meet } \\
\text { internal or external data storage requirements" }{ }^{3}\end{array}$ & $\begin{array}{l}\text { BFC } \\
\text { [ISO-IFPUG] }\end{array}$ \\
\hline $\begin{array}{l}\text { Transactional } \\
\text { function }\end{array}$ & & $\begin{array}{l}\text { "Elementary process that provides functionality } \\
\text { to the user to process data" }{ }^{3}\end{array}$ & $\begin{array}{l}\text { BFC } \\
\text { [ISO-IFPUG] }\end{array}$ \\
\hline External input & EI & $\begin{array}{l}\text { "Elementary process that processes data or } \\
\text { control information sent from outside the } \\
\text { boundary" } 3\end{array}$ & $\begin{array}{l}\text { Transactional } \\
\text { function } \\
\text { [ISO-IFPUG] }\end{array}$ \\
\hline External output & EO & $\begin{array}{l}\text { "Elementary process that sends data or control } \\
\text { information outside the boundary and includes } \\
\text { additional processing logic beyond that of an } \\
\text { External Inquiry" }{ }^{3}\end{array}$ & $\begin{array}{l}\text { Transactional } \\
\text { function } \\
\text { [ISO-IFPUG] }\end{array}$ \\
\hline External inquiry & EQ & $\begin{array}{l}\text { "Elementary process that sends data or control } \\
\text { information outside the boundary" }{ }^{3}\end{array}$ & $\begin{array}{l}\text { Transactional } \\
\text { function } \\
\text { [ISO-IFPUG] }\end{array}$ \\
\hline
\end{tabular}




\begin{tabular}{|c|c|c|c|}
\hline Names & Symbols & Definitions & References \\
\hline $\begin{array}{l}\text { Internal logical } \\
\text { file }\end{array}$ & ILF & $\begin{array}{l}\text { "User recognizable group of logically related } \\
\text { data or control information maintained within the } \\
\text { boundary of the application being measured" } 3\end{array}$ & $\begin{array}{l}\text { Data function } \\
\text { [ISO-IFPUG] }\end{array}$ \\
\hline $\begin{array}{l}\text { External interface } \\
\text { file }\end{array}$ & EIF & $\begin{array}{l}\text { "User recognizable group of logically related } \\
\text { data or control information, which is referenced } \\
\text { by the application being measured, but which is } \\
\text { maintained within the boundary of another } \\
\text { application" }{ }^{3}\end{array}$ & $\begin{array}{l}\text { Data function } \\
\text { [ISO-IFPUG] }\end{array}$ \\
\hline $\begin{array}{l}\text { Data element } \\
\text { type }\end{array}$ & DET & $\begin{array}{l}\text { "Unique, user recognizable, non-repeated } \\
\text { attribute" } \\
\text { "Unique, user-recognizable, non-repeated field in } \\
\text { a BFC" } 7\end{array}$ & $\begin{array}{l}\text { Entity } \\
\text { [ISO-IFPUG, } \\
\text { ISO-FiSMA] }\end{array}$ \\
\hline $\begin{array}{l}\text { Record element } \\
\text { type }\end{array}$ & RET & $\begin{array}{l}\text { "User recognizable sub-group of data element } \\
\text { types within a data function" }{ }^{3}\end{array}$ & $\begin{array}{l}\text { Entity } \\
\text { [ISO-IFPUG] }\end{array}$ \\
\hline $\begin{array}{l}\text { File type } \\
\text { referenced }\end{array}$ & FTR & $\begin{array}{l}\text { "Data function read and/or maintained by a } \\
\text { transactional function" } 3\end{array}$ & $\begin{array}{l}\text { Entity } \\
\text { [ISO-IFPUG] }\end{array}$ \\
\hline Data movement & & $\begin{array}{l}\text { "Base Functional Component which moves a } \\
\text { single data group" }\end{array}$ & $\begin{array}{l}\text { BFC } \\
\text { [ISO-COSMIC] }\end{array}$ \\
\hline Entry & & $\begin{array}{l}\text { "Data movement that moves a data group from a } \\
\text { functional user across the boundary into the } \\
\text { functional process where it is required" }{ }^{2}\end{array}$ & $\begin{array}{l}\text { Data movement } \\
\text { [ISO-COSMIC] }\end{array}$ \\
\hline Exit & & $\begin{array}{l}\text { "Data movement that moves a data group from a } \\
\text { functional process across the boundary to the } \\
\text { functional user that requires it" } 2\end{array}$ & $\begin{array}{l}\text { Data movement } \\
\text { [ISO-COSMIC] }\end{array}$ \\
\hline Read & & $\begin{array}{l}\text { "Data movement that moves a data group from } \\
\text { persistent storage [to] within reach of the } \\
\text { functional process which requires it" }{ }^{2}\end{array}$ & $\begin{array}{l}\text { Data movement } \\
\text { [ISO-COSMIC] }\end{array}$ \\
\hline Write & & $\begin{array}{l}\text { "Data movement that moves a data group lying } \\
\text { inside the functional process to persistent } \\
\text { storage" } 2\end{array}$ & $\begin{array}{l}\text { Data movement } \\
\text { [ISO-COSMIC] }\end{array}$ \\
\hline $\begin{array}{l}\text { Logical } \\
\text { transaction }\end{array}$ & & $\begin{array}{l}\text { "Smallest complete unit of information } \\
\text { processing that is meaningful to the end user in } \\
\text { the business" } 4\end{array}$ & $\begin{array}{l}\text { BFC } \\
\text { [ISO-MkII] }\end{array}$ \\
\hline $\begin{array}{l}\text { Input data } \\
\text { element type }\end{array}$ & $\mathrm{Ni}$ & DET that is an input to a logical transaction. & $\begin{array}{l}\text { DET } \\
\text { [ISO-MkII] }\end{array}$ \\
\hline Data entity type & $\mathrm{Ne}$ & $\begin{array}{l}\text { "Fundamental thing of relevance to the user, } \\
\text { about which information is kept." }\end{array}$ & $\begin{array}{l}\text { Entity } \\
\text { [ISO-MkII] }\end{array}$ \\
\hline $\begin{array}{l}\text { Output data } \\
\text { element type }\end{array}$ & No & DET that is an output from a logical transaction. & $\begin{array}{l}\text { DET } \\
\text { [ISO-MkII] }\end{array}$ \\
\hline $\begin{array}{l}\text { Interactive end- } \\
\text { user navigation } \\
\text { and query service }\end{array}$ & $\mathrm{q}$ & $\begin{array}{l}\text { "Interactive end-user navigation and query } \\
\text { services specify all parts of the interactive user } \\
\text { interface where there is no maintenance of } \\
\text { persistent data stored in the system." } 7 \text { Seven } \\
\text { subtypes are defined. }\end{array}$ & $\begin{array}{l}\text { BFC } \\
\text { [ISO-FiSMA] }\end{array}$ \\
\hline
\end{tabular}




\begin{tabular}{|c|c|c|c|}
\hline Names & Symbols & Definitions & References \\
\hline $\begin{array}{l}\text { Interactive end- } \\
\text { user input service }\end{array}$ & $\mathrm{i}$ & $\begin{array}{l}\text { "Interactive end-user input services specify all } \\
\text { parts of the interactive user interface where there } \\
\text { is maintenance of data store(s) of the software." } \\
\text { Three subtypes are defined. }\end{array}$ & $\begin{array}{l}\text { BFC } \\
\text { [ISO-FiSMA] }\end{array}$ \\
\hline $\begin{array}{l}\text { Non-interactive } \\
\text { end-user output } \\
\text { service }\end{array}$ & 0 & $\begin{array}{l}\text { "Non-interactive end-user output services specify } \\
\text { all parts of the user interface which are non- } \\
\text { interactive and do not maintain data store(s) of } \\
\text { the software." }{ }^{7} \text { Four subtypes are defined. }\end{array}$ & $\begin{array}{l}\text { BFC } \\
{[\text { ISO-FiSMA] }}\end{array}$ \\
\hline $\begin{array}{l}\text { Interface service } \\
\text { to other } \\
\text { applications }\end{array}$ & $\mathrm{t}$ & $\begin{array}{l}\text { "Interface services to other applications specify } \\
\text { all automatic data transfers that move data from } \\
\text { the measured piece of software to another } \\
\text { application or any device." }{ }^{7} \text { Three subtypes are } \\
\text { defined. }\end{array}$ & $\begin{array}{l}\text { BFC } \\
\text { [ISO-FiSMA] }\end{array}$ \\
\hline $\begin{array}{l}\text { Interface service } \\
\text { from other } \\
\text { applications }\end{array}$ & $\mathrm{f}$ & $\begin{array}{l}\text { "Interface services from other applications } \\
\text { specify all automatic data transfers that receive } \\
\text { data groups that are provided and sent by another } \\
\text { application or any device." }{ }^{7} \text { Three subtypes are } \\
\text { defined. }\end{array}$ & $\begin{array}{l}\text { BFC } \\
\text { [ISO-FiSMA] }\end{array}$ \\
\hline $\begin{array}{l}\text { Data storage } \\
\text { service }\end{array}$ & $\mathrm{d}$ & $\begin{array}{l}\text { "Data storage services specify a group or } \\
\text { collection of related and self-contained data in } \\
\text { the real world, about which the user requires the } \\
\text { software to provide one or more data stores." } 7 \\
\text { Two subtypes are defined. }\end{array}$ & $\begin{array}{l}\text { BFC } \\
\text { [ISO-FiSMA] }\end{array}$ \\
\hline $\begin{array}{l}\text { Algorithmic and } \\
\text { manipulation } \\
\text { service }\end{array}$ & $\bar{a}$ & $\begin{array}{l}\text { "Algorithmic and manipulation services are user- } \\
\text { defined, independent data manipulation } \\
\text { functions." }{ }^{7} \text { Six subtypes are defined. }\end{array}$ & $\begin{array}{l}\text { BFC } \\
\text { [ISO-FiSMA] }\end{array}$ \\
\hline $\begin{array}{l}\text { Reading } \\
\text { reference }\end{array}$ & & $\begin{array}{l}\text { "Data storage entity or record, or interface record } \\
\text { from another software or system containing data } \\
\text { retrieved in a BFC" } 7\end{array}$ & $\begin{array}{l}\text { Entity } \\
\text { [ISO-FiSMA] }\end{array}$ \\
\hline Writing reference & & $\begin{array}{l}\text { "Data storage entity or other record, or interface } \\
\text { record to another software or system to which } \\
\text { data is written in a BFC" }{ }^{7}\end{array}$ & $\begin{array}{l}\text { Entity } \\
\text { [ISO-FiSMA] }\end{array}$ \\
\hline Operation & & $\begin{array}{l}\text { "Arithmetic or logical operation performed in an } \\
\text { algorithmic and manipulation BFC" } 7\end{array}$ & $\begin{array}{l}\text { Entity } \\
\text { [ISO-FiSMA] }\end{array}$ \\
\hline
\end{tabular}

\subsection{Units of failure, interruption, and termination}

\begin{tabular}{|l|l|l|l|}
\hline Names & Symbols & Definitions & References \\
\hline Fault & & $\begin{array}{l}\text { "Incorrect step, process, or data definition in a } \\
\text { computer program." }\end{array}$ & $\begin{array}{l}\text { Entity } \\
\text { [ISO-Vocab] }\end{array}$ \\
\hline Failure & & $\begin{array}{l}\text { "Event in which a system or system component does } \\
\text { not perform a required function within specified } \\
\text { limits." }\end{array}$ & $\begin{array}{l}\text { Event } \\
\text { [ISO-Vocab- } \\
\text { 2010] }\end{array}$ \\
\hline
\end{tabular}




\begin{tabular}{|l|l|l|l|}
\hline Names & Symbols & Definitions & References \\
\hline Error & $\begin{array}{l}\text { An incorrect result; a "difference between a computed, } \\
\text { observed, or measured value or condition and the true, } \\
\text { specified, or theoretically correct value or condition." }\end{array}$ & $\begin{array}{l}\text { Entity } \\
\text { [ISO-Vocab] }\end{array}$ \\
\hline $\begin{array}{l}\text { Bug, } \\
\text { Defect }\end{array}$ & $\begin{array}{l}\text { Less formal terms that may mean either fault or error } \\
\text { depending on context and viewpoint. The relationship } \\
\text { between errors observed by users and faults } \\
\text { identified by developers is many-to-many. }\end{array}$ & Entity \\
\hline $\begin{array}{l}\text { Bug report, } \\
\text { Problem report }\end{array}$ & $\begin{array}{l}\text { Event of a user or tester asserting the existence of a } \\
\text { fault in the software. }\end{array}$ & Event \\
\hline Weakness & Fault that is security-relevant. & Fault \\
\hline Vulnerability & Weakness that is exploitable. & $\begin{array}{l}\text { Weakness } \\
\text { [SP800-30r1] }\end{array}$ \\
\hline Panic & $\begin{array}{l}\text { Self-initiated emergency stop of an operating system } \\
\text { kernel. }\end{array}$ & Crash \\
\hline Crash & Emergency stop of a running process. & Failure \\
\hline Hang & Failure of a process to make progress. & Failure \\
\hline Lockup & $\begin{array}{l}\text { Hang accompanied by abnormal unresponsiveness to } \\
\text { signals or control inputs. }\end{array}$ & Hang \\
\hline Abort & $\begin{array}{l}\text { Controlled interruption and shutdown of a running } \\
\text { process that has not reached its "normal" termination } \\
\text { point. }\end{array}$ & Exit \\
\hline Exit & Controlled termination of a running process. & Event \\
\hline Timeout & Event of a latency exceeding a threshold value. & Event \\
\hline Exception & $\begin{array}{l}\text { "Abnormal" event that necessitates the "normal" flow } \\
\text { of control of a running process to be interrupted. (See } \\
\text { also the source code entity.) }\end{array}$ & $\begin{array}{l}\text { Event } \\
\text { [ISO-Vocab] }\end{array}$ \\
\hline Interrupt & $\begin{array}{l}\text { "Suspension of a process to handle an event external } \\
\text { to the process." } 6\end{array}$ & $\begin{array}{l}\text { Event } \\
\text { [ISO-Vocab] }\end{array}$ \\
\hline Signal & $\begin{array}{l}\text { Specific kind of interrupt on Unix-like operating } \\
\text { systems. }\end{array}$ & Interrupt \\
\hline
\end{tabular}

\subsection{Profiling units}

\begin{tabular}{|l|l|l|l|}
\hline Names & Symbols & Definitions & References \\
\hline $\begin{array}{l}\text { Call, } \\
\text { Invocation, } \\
\text { Message }\end{array}$ & $\begin{array}{l}\text { Event of pushing the current function onto the stack and } \\
\text { transferring control to another function. Not to be confused } \\
\text { with the source code entity that causes it to occur. } \\
\text { The term "message" is used for Smalltalk and Objective C. }\end{array}$ & Event \\
\hline Sample & $\begin{array}{l}\text { Event of a profiling interrupt being fired. In non-intrusive } \\
\text { profiling, the execution of a program is "sampled" either at } \\
\text { periodic intervals or at aperiodic times when arbitrary, } \\
\text { defined conditions are met. }\end{array}$ & Event \\
\hline
\end{tabular}




\begin{tabular}{|l|l|l|l|}
\hline Names & Symbols & Definitions & References \\
\hline Cycle & $\begin{array}{l}\text { A single "tick" of the internal clock source of a processing } \\
\text { unit such as a Central Processing Unit (CPU) or Graphics } \\
\text { Processing Unit (GPU). }\end{array}$ & Event \\
\hline Operation & $\begin{array}{l}\text { Unspecified unit of processing used to parameterize } \\
\text { algorithmic performance and throughput metrics. Not to be } \\
\text { confused with operation as machine code instruction } \\
\text { (elementary entity) or source code entity. }\end{array}$ & Event \\
\hline Iteration & $\begin{array}{l}\text { Single execution of the block inside a looping control } \\
\text { construct. }\end{array}$ & Event \\
\hline Run & $\begin{array}{l}\text { Single execution of a program, from start to exit or crash. } \\
\text { Transaction }\end{array}$ & $\begin{array}{l}\text { Application-specific unit of processing, usually intended to } \\
\text { execute atomically. }\end{array}$ & Event \\
\hline Resource & $\begin{array}{l}\text { "Any physical or virtual component of limited availability } \\
\text { within a computer system available for a given purpose and } \\
\text { managed by the runtime platform." } \\
\text { cores, file descriptors, memory. }\end{array}$ & $\begin{array}{l}\text { Entity } \\
\text { [ISO- } \\
\text { Vocab] }\end{array}$ \\
\hline
\end{tabular}

\subsection{Testing units}

\begin{tabular}{|l|l|l|l|}
\hline Names & Symbols & Definitions & References \\
\hline $\begin{array}{l}\text { Variable-value } \\
\text { configuration }\end{array}$ & $\begin{array}{l}\text { For a set of } t \text { variables, a variable-value configuration is } \\
\text { a set of } t \text { valid values, one for each of the variables. For } \\
\text { test coverage purposes, a finite and practically testable } \\
\text { set of values is selected and deemed "valid" for each } \\
\text { variable. In design-of-experiments vocabulary, the } \\
\text { variables are factors, the values are levels, and the } \\
\text { variable-value configurations are treatments. }\end{array}$ & $\begin{array}{l}\text { Entity } \\
\text { [Kuhn] }\end{array}$ \\
\hline $\begin{array}{l}\text { Combination } \\
\text { sequence and } \\
\text { jump, } \\
\text { Jump-to-jump } \\
\text { path }\end{array}$ & $\begin{array}{l}\text { JJ-path } \\
\text { (the standard definition from combinatorics) }\end{array}$ & $\begin{array}{l}\text { An LCSAJ triple "consists of a linear sequence of } \\
\text { code... plus a jump to a particular location." For Fortran } \\
\text { programs, the start point of a LCSAJ "is either the first } \\
\text { line of the program or any line which has a jump to it } \\
\text { from elsewhere in the program, other than the } \\
\text { preceeding line," and the end point "is either the end of } \\
\text { the program or a line which contains a jump to other } \\
\text { than the succeeding line." }\end{array}$ & $\begin{array}{l}\text { Entity } \\
\text { [Kuhn] }\end{array}$ \\
\hline
\end{tabular}

\section{Dimensions}

See Sec. 0.4 for background. The legitimacy of data and information as dimensions, and of cycles and samples as units of time, need not be defended here. The purpose of this chapter is simply to identify the ranges of alternative units that could be used when one of the following dimensions is referenced in subsequent sections. 


\begin{tabular}{|c|c|c|c|}
\hline Names & Symbols & Definitions & References \\
\hline Time & T & $\begin{array}{l}\text { All conventional units of time longer than the } \\
\text { second have multiple, competing definitions. E.g., } \\
\text { the existence of leap seconds confounds the } \\
\text { definition of a minute as } 60 \mathrm{~s} \text {, an hour as } 3600 \mathrm{~s} \text {, } \\
\text { etc.; summer time (daylight savings time) causes } \\
\text { certain days to contain more or fewer than } 24 \\
\text { hours; and conflicting definitions of the year } \\
\text { (calendar years and astronomical years) are most } \\
\text { notorious. }\end{array}$ & $\begin{array}{l}\text { second [SI], minute, } \\
\text { hour, day..., } \\
\text { cycle, } \\
\text { sample }\end{array}$ \\
\hline Data & & & $\begin{array}{l}\text { bit, } \\
\text { byte, } \\
\text { data object }\end{array}$ \\
\hline Information & & & $\begin{array}{l}\text { shannon (a.k.a. "bit" } \\
\text { of information), } \\
\text { hartley, nat [IEC] }\end{array}$ \\
\hline Work & & $\begin{array}{l}\text { The essential product of a processing unit (Central } \\
\text { Processing Unit (CPU), Graphics Processing Unit } \\
\text { (GPU), or suchlike). }\end{array}$ & $\begin{array}{l}\text { transaction, } \\
\text { iteration, } \\
\text { operation (event), } \\
\text { instruction (entity) }\end{array}$ \\
\hline
\end{tabular}

\section{Basic quantities}

\subsection{Physical quantities}

It should be noted that the relative quantities given below are seldom identified as such in practice; e.g., both self time and relative self time are just called "self time."

\begin{tabular}{|c|c|c|c|}
\hline Names & Symbols & Definitions & References \\
\hline $\begin{array}{l}\text { Execution time, } \\
\text { Run time, } \\
\text { Wall time, } \\
\text { Wall clock time, } \\
\text { Elapsed time, } \\
\text { Real time, } \\
\text { Real world time }\end{array}$ & & $\begin{array}{l}\text { Time that a process takes to run, or that a } \\
\text { process or system has been monitored. }\end{array}$ & Dimension: time \\
\hline Resource time & & $\begin{array}{l}\text { Time that a specified class of resource was } \\
\text { used, possibly by a specified process, } \\
\text { thread, or group thereof. Resource time } \\
\text { may exceed elapsed time if more than one } \\
\text { resource (e.g., multiple CPU cores) was } \\
\text { used. }\end{array}$ & Dimension: time \\
\hline
\end{tabular}




\begin{tabular}{|l|l|l|l|}
\hline Names & Symbols & Definitions & References \\
= Resource time / real time \\
time, \\
$\begin{array}{l}\text { Resource } \\
\text { utilization } \\
\text { This value may exceed unity if more than } \\
\text { one resource (e.g., multiple CPU cores) } \\
\text { was used. } \\
\text { C.f. resource utilization in the next section } \\
\text { (same name, different quantity). }\end{array}$ & Dimension: time/time \\
\hline Self time & $\begin{array}{l}\text { Time that a specified function was } \\
\text { executing (running), i.e., that the } \\
\text { instruction being executed by the CPU was } \\
\text { actually part of that function. }\end{array}$ & Dimension: time \\
$=$ Self time / CPU time & $\begin{array}{l}\text { Time that a specified function either was } \\
\text { executing (self time) or was on the stack } \\
\text { (while a called subfunction or event } \\
\text { handler was being executed). }\end{array}$ & Dimension: time \\
\hline Relative self time & = Total time / CPU time \\
\hline Total time & $\begin{array}{l}\text { Time between the final event that enables } \\
\text { or causes something to occur and the event } \\
\text { of it actually occurring. }\end{array}$ & Dimension: time \\
\hline $\begin{array}{l}\text { Relative total } \\
\text { time }\end{array}$ & $\begin{array}{l}\text { Latency, } \\
\text { Delay, } \\
\text { Lag, } \\
\text { Response time }\end{array}$ & $\begin{array}{l}\text { Amount of energy (generally electric) used } \\
\text { to run a process. }\end{array}$ & $\begin{array}{l}\text { Unit: J (joule) [SI] or } \\
\text { the non-SI kWh } \\
\text { (kilowatt hour). }\end{array}$ \\
\hline Energy & Rate of energy use for running a process. & $\begin{array}{l}\text { Unit: W (watt) = J/s } \\
\text { [SI] }\end{array}$ \\
\hline Power & & & Dimension: time/time \\
\hline
\end{tabular}

\subsection{Resources, processing, and transmission}

\begin{tabular}{|c|c|c|c|}
\hline Names & Symbols & Definitions & References \\
\hline Size & & [Of a data object] & Dimension: data \\
\hline $\begin{array}{l}\text { Storage capacity, } \\
\text { Storage size }\end{array}$ & $\mathrm{M}$ & $\begin{array}{l}\text { "Amount of data that can be contained } \\
\text { in a storage device, expressed as a } \\
\text { number of specified data elements" } 8 \\
\text { "Storage" here generalizes all kinds of } \\
\text { memory, hard disks (HDD), solid state } \\
\text { devices (SSD), etc., and the "device" } \\
\text { may be either physical or logical. } \\
\text { 'M' is also used for mass fraction and } \\
\text { as the prefix for } 10^{6} \text {. }\end{array}$ & $\begin{array}{l}\text { Dimension: data } \\
\text { [IEC] }\end{array}$ \\
\hline
\end{tabular}




\begin{tabular}{|c|c|c|c|}
\hline Names & Symbols & Definitions & References \\
\hline Resource utilization & & $\begin{array}{l}\text { Proportion of the resources of a } \\
\text { specified class that were used. C.f. } \\
\text { resource utilization = relative resource } \\
\text { time in the previous section (same } \\
\text { name, different quantity). }\end{array}$ & $\begin{array}{l}\text { Unit: } \\
\text { resource/resource }\end{array}$ \\
\hline Storage utilization & & $\begin{array}{l}\text { Proportion of storage capacity used; } \\
\text { i.e., resource utilization where the } \\
\text { resource is storage. }\end{array}$ & Dimension: data/data \\
\hline Transfer rate & r, & $\begin{array}{l}\text { "Quotient of the number of specified } \\
\text { data elements transferred in a time } \\
\text { interval by the duration of this } \\
\text { interval" } 8\end{array}$ & $\begin{array}{l}\text { Dimension: data/time } \\
\text { [IEC] }\end{array}$ \\
\hline Bandwidth & & $\begin{array}{l}\text { Maximum available transfer rate; } \\
\text { transfer capacity. }\end{array}$ & Dimension: data/time \\
\hline Throughput & & $\begin{array}{l}\text { Work performed in a given period of } \\
\text { time. }\end{array}$ & $\begin{array}{l}\text { Dimension: } \\
\text { work/time } \\
\text { [ISO-Vocab] }\end{array}$ \\
\hline Information content & $\mathrm{I}(\mathrm{x})$ & $\begin{array}{l}=\log _{2} \frac{1}{p(x)} \text { Sh } \\
\text { where } \mathrm{p}(\mathrm{x}) \text { is the probability of event } \\
\mathrm{x}^{8}{ }^{8}\end{array}$ & $\begin{array}{l}\text { Dimension: } \\
\text { information } \\
\text { [IEC] }\end{array}$ \\
\hline $\begin{array}{l}\text { Compression ratio } \\
\text { (storage) }\end{array}$ & & $\frac{\text { Uncompressed size }}{\text { Compressed size }}$ & Dimension: data/data \\
\hline $\begin{array}{l}\text { Compression ratio } \\
\text { (transmission) }\end{array}$ & & $\frac{\text { Uncompressed transfer rate }}{\text { Compressed transfer rate }}$ & $\begin{array}{l}\text { Dimension: } \\
\text { (data/time)/(data/time) }\end{array}$ \\
\hline
\end{tabular}

\subsection{Graph metrics}

Many software metrics are derived using a graph model of the software, such as a control flow graph, data flow graph, call graph, dependency graph, or attack graph. The following metrics apply to graphs in general (directed, undirected, or both). 


\begin{tabular}{|c|c|c|c|}
\hline Names & Symbols & Definitions & References \\
\hline $\begin{array}{l}\text { Cyclomatic } \\
\text { number, } \\
\text { First Betti } \\
\text { number, } \\
\text { Circuit rank, } \\
\text { Nullity }\end{array}$ & $\begin{array}{l}V(G) \\
v(G)\end{array}$ & $\begin{array}{l}\text { The number of independent elementary } \\
\text { cycles in a graph, derived as } \\
e-n+p \\
\text { Where: } \\
e \text { is number of edges } \\
n \text { is number of nodes } \\
p \text { is number of connected components }\end{array}$ & $\begin{array}{l}\text { Unit: elementary cycle } \\
\text { Cyclomatic number is } \\
\text { defined for undirected } \\
\text { graphs. } \\
\text { The same number is } \\
\text { indicative of several different } \\
\text { things. See Wikipedia, } \\
\text { "circuit rank," for alternative } \\
\text { uses. } \\
\text { [Berge] } \\
\text { See also, cyclomatic } \\
\text { complexity in Sec. 6.4. }\end{array}$ \\
\hline $\begin{array}{l}\text { Depth (of } \\
\text { graph) }\end{array}$ & & $\begin{array}{l}\text { "Length of the longest path from the } \\
\text { root node to a leaf node." }\end{array}$ & $\begin{array}{l}\text { Unit: arc } \\
\text { [Fenton, p. 405] }\end{array}$ \\
\hline Width & & $\begin{array}{l}\text { "Maximum number of nodes at any one } \\
\text { level." }\end{array}$ & $\begin{array}{l}\text { Unit: node } \\
\text { [Fenton, p. 405] }\end{array}$ \\
\hline $\begin{array}{l}\text { Edge-to-node } \\
\text { ratio }\end{array}$ & & & $\begin{array}{l}\text { Unit: edge/node } \\
\text { [Fenton, p. 405] }\end{array}$ \\
\hline
\end{tabular}

[Fenton, p. 405] further notes that graph size may be measured by the counts of nodes and edges (Sec. 2.3).

In addition, the following metrics apply to a given node within a graph.

\begin{tabular}{|l|l|l|l|}
\hline \multicolumn{1}{|c|}{ Names } & Symbols & \multicolumn{1}{|c|}{ Definitions } & \multicolumn{1}{|c|}{ References } \\
\hline Depth (of node) & $\begin{array}{l}\text { Length of the longest path from the } \\
\text { root node to a given node }\end{array}$ & $\begin{array}{l}\text { Unit: arc } \\
\text { [Zuse] }\end{array}$ \\
\hline $\begin{array}{l}\text { Number of ancestors / } \\
\text { ascendents }\end{array}$ & $\begin{array}{l}\text { Number of nodes that are reachable } \\
\text { from a given node by following edges } \\
\text { toward the root. }\end{array}$ & $\begin{array}{l}\text { Unit: node } \\
\text { [Zuse] }\end{array}$ \\
\hline $\begin{array}{l}\text { Number of descendants / } \\
\text { successors }\end{array}$ & $\begin{array}{l}\text { Number of nodes that can reach a } \\
\text { given node by following edges } \\
\text { toward the root. }\end{array}$ & $\begin{array}{l}\text { Unit: node } \\
\text { [Zuse] }\end{array}$ \\
\hline $\begin{array}{l}\text { Proportion of ancestors / } \\
\text { ascendents }\end{array}$ & $\begin{array}{l}\text { Number of ancestors divided by the } \\
\text { number of nodes. }\end{array}$ & Unit: node/node \\
\hline $\begin{array}{l}\text { Proportion of descendants / } \\
\text { successors }\end{array}$ & $\begin{array}{l}\text { Number of descendants divided by } \\
\text { the number of nodes. }\end{array}$ & Unit: node/node \\
\hline
\end{tabular}

\section{Compatibility metrics}

Compatibility metrics indicate the CPU architectures, operating systems, and user environments with which software is compatible. Note that "fat binaries" may support multiple, mutually incompatible architectures and operating systems. 
The terms in all capital letters in the table below are a mixture of acronyms, former acronyms that evolved into proper names, and acronym-like names that were invented for branding purposes. ARM, CP/M, DOS, and MIPS are proper names in current usage; their historical expansions are irrelevant. The instruction set extensions are commonly expanded as follows:

$\begin{array}{ll}\text { ADX } & \text { Multi-precision add-carry instruction extensions } \\ \text { AVX } & \text { Advanced Vector Extensions } \\ \text { DSP } & \text { Digital Signal Processing } \\ \text { MMX } & \text { Multimedia Extensions } \\ \text { MPX } & \text { Memory Protection Extensions } \\ \text { SGX } & \text { Software Guard Extensions } \\ \text { SIMD } & \text { Single Instruction, Multiple Data } \\ \text { SSE } & \text { Streaming SIMD (Single Instruction, Multiple Data) Extensions } \\ \text { TSX } & \text { Transactional Synchronization Extensions } \\ \text { TXT } & \text { Trusted Execution Technology } \\ \text { VFP } & \text { Vector Floating Point } \\ \text { VT-d } & \text { Virtualization Technology for directed input/output } \\ \text { VT-X } & \text { Virtualization Technology extensions }\end{array}$

\begin{tabular}{|c|c|c|c|}
\hline Names & Symbols & Definitions & References \\
\hline $\begin{array}{l}\text { Architecture, } \\
\text { Instruction set } \\
\text { architecture }\end{array}$ & ISA & $\begin{array}{l}\text { E.g., x86, ARM, or MIPS. } \\
\text { By convention, x86-64 is often listed separately from } \\
\text { x86, but technically it is x86 with 64-bit extensions. }\end{array}$ & Nominal set \\
\hline Word size & & $\begin{array}{l}\text { Historically, "the number of bits in a word." In } \\
\text { current practice, it identifies classes of platforms } \\
\text { with an implied ordering of relative capability: } \\
\text { 4-bit = mostly embedded controllers } \\
\text { 8-bit = vintage computer } \\
\text { 16-bit = DOS, CP/M } \\
\text { 32-bit = legacy and low-end, } \leq 4 \mathrm{GiB} \text { RAM } \\
\text { 64-bit = mainstream, } \geq 4 \mathrm{GiB} \text { RAM }\end{array}$ & $\begin{array}{l}\text { Unit: bit } \\
\text { (for } \\
\text { historical } \\
\text { usage) or } \\
\text { ordinal (as a } \\
\text { platform } \\
\text { classifier) }\end{array}$ \\
\hline Microarchitecture & & $\begin{array}{l}\text { Name of the oldest and/or simplest processor } \\
\text { microarchitecture that is capable of running the } \\
\text { software. Within a sequence of backward- } \\
\text { compatible microarchitecture iterations, the values } \\
\text { form an ordinal scale. E.g., } \\
\text { Prescott }<\text { Core }<\text { Nehalem }<\text { Sandy Bridge }< \\
\text { Haswell }<\text { Skylake } \\
\text { ARMv1 }<\text { ARMv2 }<\text { ARMv2a }<\text { ARMv3 etc. }\end{array}$ & $\begin{array}{l}\text { Nominal set } \\
\text { or ordinal }\end{array}$ \\
\hline
\end{tabular}




\begin{tabular}{|c|c|c|c|}
\hline Names & Symbols & Definitions & References \\
\hline $\begin{array}{l}\text { Instruction set } \\
\text { extensions }\end{array}$ & & $\begin{array}{l}\text { Names of "additional" or "supplementary" sets of } \\
\text { instructions that are needed to run the software. E.g., } \\
\text { x86-64, MMX, 3DNow, SSE, SSE2, ..., SSE4.2, } \\
\text { ADX, AVX, AVX2, AVX-512, MPX, TXT, TSX, } \\
\text { SGX, VT-x, VT-d } \\
\text { AArch64, Thumb, Thumb-2, DSP, SIMD, VFPv1, } \\
\text { VFPv2, ..., VFPv5-D16-M, Neon }\end{array}$ & Nominal set \\
\hline Operating system & & $\begin{array}{l}\text { Versions of operating systems that are able to run the } \\
\text { software. Within a sequence of backward- } \\
\text { compatible iterations, the values form an ordinal } \\
\text { scale. }\end{array}$ & $\begin{array}{l}\text { Nominal set } \\
\text { or ordinal }\end{array}$ \\
\hline $\begin{array}{l}\text { Privileges, } \\
\text { Roles }\end{array}$ & & $\begin{array}{l}\text { Security properties that must be granted for the } \\
\text { software to run. E.g., root or administrator, or access } \\
\text { to file system, location, contacts database, camera, or } \\
\text { microphone. }\end{array}$ & Nominal set \\
\hline
\end{tabular}

\section{Algorithm metrics}

\subsection{Performance}

Computational and space complexity are typically quoted for best, average, and worst cases, using big O notation.

\begin{tabular}{|c|c|c|c|}
\hline Names & Symbols & Definitions & References \\
\hline $\begin{array}{l}\text { Computational } \\
\text { complexity, } \\
\text { Time complexity }\end{array}$ & & $\begin{array}{l}\text { Number of operations required, expressed } \\
\text { as a function of the number of data objects } \\
\text { in the input. }\end{array}$ & Unit: operation \\
\hline $\begin{array}{l}\text { Memory } \\
\text { complexity, } \\
\text { Space complexity }\end{array}$ & & $\begin{array}{l}\text { Amount of storage required, expressed as a } \\
\text { function of the number of data objects in } \\
\text { the input. }\end{array}$ & Dimension: data \\
\hline $\begin{array}{l}\text { Computational } \\
\text { efficiency, } \\
\text { Time efficiency }\end{array}$ & & $\begin{array}{l}\text { Ratio of the theoretical minimum number } \\
\text { of operations required divided by the } \\
\text { computational complexity of the } \\
\text { algorithm. }\end{array}$ & $\begin{array}{l}\text { Unit: } \\
\text { operation/operation }\end{array}$ \\
\hline $\begin{array}{l}\text { Memory efficiency, } \\
\text { Space efficiency }\end{array}$ & & $\begin{array}{l}\text { Ratio of the theoretical minimum amount } \\
\text { of storage required divided by the space } \\
\text { complexity of the algorithm. }\end{array}$ & $\begin{array}{l}\text { Dimension: } \\
\text { data/data }\end{array}$ \\
\hline
\end{tabular}

\subsection{Hash function metrics}

Attack resistance refers to the amount of work (e.g., number of hash function evaluations) that is expected to be required for an attack to succeed. Depending on context, the "expectation" may be an upper bound (i.e., what is required to complete an exhaustive 
search), a statistical average, or an order-of-magnitude estimate; the amounts required in a particular case may be more or less, and there can be tradeoffs.

\begin{tabular}{|l|l|l|l|}
\hline Names & Symbols & Definitions & References \\
\hline [Max] message size & $\begin{array}{l}\text { Maximum allowed size of the input to a hash } \\
\text { function. If length size (see below) }=\text { l bits, } \\
\text { then message size }=2^{l}-1 \text { bits. }\end{array}$ & Dimension: data \\
\hline Length size & $\begin{array}{l}\text { Size of the scalar data item used to record } \\
\text { the length of the message. }\end{array}$ & Dimension: data \\
\hline $\begin{array}{l}\text { Output size, } \\
\text { size, } \\
\text { Hash value size }\end{array}$ & Size of the output of a hash function. & Dimension: data \\
\hline Internal state size & & Size of the intermediate hash result. & Dimension: data \\
\hline Block size & $\begin{array}{l}\text { Size of the data segments into which the } \\
\text { input is separated for processing. }\end{array}$ & Dimension: data \\
\hline Number of rounds & $\begin{array}{l}\text { Number of iterations of the work within the } \\
\text { hash algorithm. }\end{array}$ & Unit: iteration \\
\hline $\begin{array}{l}\text { Security bits, } \\
\text { Security strength }\end{array}$ & $\begin{array}{l}\text { log2 of the value of one of the following four } \\
\text { resistance quantities. }\end{array}$ & $\begin{array}{l}\text { Dimension: work } \\
\text { Logarithmic scale }\end{array}$ \\
\hline $\begin{array}{l}\text { Collision resistance } \\
\text { two inputs that produce the same hash value. }\end{array}$ & $\begin{array}{l}\text { Expected amount of work required to find } \\
\text { two inputs that produce the same hash value } \\
\text { when the beginning of each input has been } \\
\text { predetermined. }\end{array}$ & Dimension: work \\
\hline $\begin{array}{l}\text { Chosen prefix } \\
\text { collision resistance } \\
\text { resistance }\end{array}$ & $\begin{array}{l}\text { Expected amount of work required to find an } \\
\text { input that has a specific hash value. }\end{array}$ & $\begin{array}{l}\text { Expected amount of work required to find a } \\
\text { second input that has the same hash value as } \\
\text { a specified input. }\end{array}$ & Dimension: work \\
\hline Preimage resistance & & & Dimension: work \\
\hline
\end{tabular}

\subsection{Block cipher metrics}

In cryptography jargon, the "time/memory/data" triple refers to the amount of work (e.g., number of cipher evaluations), the amount of storage (memory), and the amount of input data (e.g., number of known plaintext-ciphertext pairs) respectively that are expected to be required for an attack to succeed. Depending on context, the "expectation" may be an upper bound (i.e., what is required to complete an exhaustive search), a statistical average, or an order-of-magnitude estimate; the amounts required in a particular case may be more or less, and there can be tradeoffs. Work may be divided between a "preprocessing" phase and a "realtime" phase. 


\begin{tabular}{|l|l|l|l|}
\hline Names & Symbols & Definitions & References \\
\hline $\begin{array}{l}\text { Block size, } \\
\text { Block length }\end{array}$ & $N b$ & $\begin{array}{l}\text { Amount of data that comprises each of the input } \\
\text { block, output block, state (intermediate cipher } \\
\text { result), and round key. }\end{array}$ & $\begin{array}{l}\text { Dimension: data } \\
\text { [FIPS 197] }\end{array}$ \\
\hline $\begin{array}{l}\text { Key size, } \\
\text { Key length }\end{array}$ & $N k$ & $\begin{array}{l}\text { Size of the cipher key that is used by the key } \\
\text { expansion routine to generate a set of round keys. }\end{array}$ & $\begin{array}{l}\text { Dimension: data } \\
\text { [FIPS 197] }\end{array}$ \\
\hline $\begin{array}{l}\text { Word size, } \\
\text { Word length }\end{array}$ & $N r$ & $\begin{array}{l}\text { Size of the data objects in each column of the state } \\
\text { array. }\end{array}$ & $\begin{array}{l}\text { Dimension: data } \\
\text { [FIPS 197] }\end{array}$ \\
\hline $\begin{array}{l}\text { Number of } \\
\text { rounds }\end{array}$ & $\begin{array}{l}\text { Number of iterations of the work within the cipher } \\
\text { algorithm (including the final iteration, which is a } \\
\text { special case) }\end{array}$ & $\begin{array}{l}\text { Unit: iterations } \\
\text { [FIPS 197] }\end{array}$ \\
\hline $\begin{array}{l}\text { Key recovery } \\
\text { resistance }\end{array}$ & $\begin{array}{l}\text { Expected amount of work, storage, and/or input } \\
\text { data required to determine the cipher key. }\end{array}$ & $\begin{array}{l}\text { Dimensions: } \\
\text { work, data, data }\end{array}$ \\
\hline $\begin{array}{l}\text { Plaintext } \\
\text { recovery } \\
\text { resistance }\end{array}$ & $\begin{array}{l}\text { Expected amount of work, storage, and/or input } \\
\text { data required to determine the plaintext. }\end{array}$ & $\begin{array}{l}\text { Dimensions: } \\
\text { work, data, data }\end{array}$ \\
\hline $\begin{array}{l}\text { Distinguishing } \\
\text { resistance }\end{array}$ & $\begin{array}{l}\text { Expected amount of work, storage, and/or input } \\
\text { data required to distinguish encrypted data from } \\
\text { random data. }\end{array}$ & $\begin{array}{l}\text { Dimensions: } \\
\text { work, data, data }\end{array}$ \\
\hline
\end{tabular}

\subsection{Cyclomatic complexity}

Cyclomatic complexity is derived from the control flow graph of a program. It is based on the more generic cyclomatic number from graph theory (see Sec. 4.3).

As specified in [McCabe, Section V], compound predicates such as "if C1 and C2" and case statements should be reduced to simple conditionals, "if C1 then if C2 then," before counting. Failure to note this apparently gave rise to so-called extended cyclomatic complexity, which in fact merely corrects for a faulty reading of the original quantity.

The only primary source that is cited for extended cyclomatic complexity is [MyersCC]. This reference is problematic for two reasons. First, it asserts that there is ambiguity about how compound predicates should be counted, without mentioning the specification in [McCabe, Section V]. Second, what it proposes is not a scalar metric, as [Welker] and [Oy] assume it to be, but an interval that covers both the greedy and conservative methods of counting. 


\begin{tabular}{|c|c|c|c|}
\hline \multirow{2}{*}{$\begin{array}{c}\text { Names } \\
\text { Cyclomatic } \\
\text { complexity }\end{array}$} & Symbols & Definitions & References \\
\hline & $\begin{array}{l}\mathrm{V}(\mathrm{G}) \\
\mathrm{v}(\mathrm{G}) \\
\mathrm{CC}\end{array}$ & $\begin{array}{l}\text { The number of linearly independent } \\
\text { paths in a control flow graph, derived as } \\
e-n+2 p \\
\text { Where: } \\
e \text { is number of edges } \\
n \text { is number of nodes } \\
p \text { is number of connected components } \\
\text { Alternate derivation: } \\
d+1 \\
\text { Where } d \text { is the number of predicate } \\
\text { nodes. }\end{array}$ & $\begin{array}{l}\text { Unit: path } \\
\text { The scale is ratio as long as } \\
\mathrm{V}(\mathrm{G}) \text { is treated only as a } \\
\text { count of linearly independent } \\
\text { paths. As a measure of } \\
\text { complexity, the scale is } \\
\text { ordinal. } \\
\text { [McCabe] } \\
\text { See also, cyclomatic number } \\
\text { in Sec. 4.3. }\end{array}$ \\
\hline $\begin{array}{l}\text { "Extended" } \\
\text { cyclomatic } \\
\text { complexity }\end{array}$ & $\begin{array}{l}\text { V(g'), } \\
\text { v(g'), } \\
\text { CC2, } \\
\text { VG2 }\end{array}$ & $=V(G)$ & See section comments above. \\
\hline
\end{tabular}

\subsection{Woodward, Hennell, and Hedley complexity}

This measure of control flow complexity is most accurately derived from source code or pseudocode that has been annotated with arrows corresponding to jumps. If it is derived from a control flow graph instead, only upper and lower bounds can be calculated.

\begin{tabular}{|l|l|l|l|}
\hline \multicolumn{1}{|c|}{ Names } & Symbols & \multicolumn{1}{c|}{ Definitions } & References \\
\hline $\begin{array}{l}\text { Woodward, } \\
\text { Hennell, and } \\
\text { Hedley complexity }\end{array}$ & & $\begin{array}{l}\text { Number of knots in the graph that results from } \\
\text { drawing arrowed lines on one side of the source } \\
\text { code indicating where a jump occurs from one } \\
\text { line of code to another. }\end{array}$ & $\begin{array}{l}\text { Unit: knot } \\
\text { [Woodward] }\end{array}$ \\
\hline
\end{tabular}

\section{General design and implementation metrics}

\subsection{Generic quantities}

\begin{tabular}{|c|c|c|c|}
\hline Names & Symbols & Definitions & References \\
\hline $\begin{array}{l}\text { Fanin, } \\
\text { Fan-in }\end{array}$ & & $\begin{array}{l}\text { (1) The number of calls (source code } \\
\text { entity, not event) to a given module. } \\
\text { (2) "Number of local flows into } \\
\text { procedure } A \text { plus the number of data } \\
\text { structures from which procedure } A \\
\text { retrieves information." }\end{array}$ & $\begin{array}{l}\text { (1) Unit: call } \\
\text { (2) Unit: data flow } \\
\text { [Henry] }\end{array}$ \\
\hline
\end{tabular}




\begin{tabular}{|c|c|c|c|}
\hline Names & Symbols & Definitions & References \\
\hline $\begin{array}{l}\text { Fanout, } \\
\text { Fan-out }\end{array}$ & & $\begin{array}{l}\text { (1) The number of calls (source code } \\
\text { entity, not event) from a given module. } \\
\text { (2) "Number local flows from procedure } \\
\text { A plus the number of data structures } \\
\text { which procedure } A \text { updates." }\end{array}$ & $\begin{array}{l}\text { (1) Unit: call } \\
\text { (2) Unit: data flow } \\
\text { [Henry] }\end{array}$ \\
\hline Number of entries & $e_{i}$ & $\begin{array}{l}\text { "Number of entry points for the } i \text { th } \\
\text { module." } 9\end{array}$ & $\begin{array}{l}\text { Unit: entry point } \\
\text { [IEEE-982.1-1988] }\end{array}$ \\
\hline Number of exits & $x_{i}$ & $\begin{array}{l}\text { "Number of exit points for the ith } \\
\text { module." } 9\end{array}$ & $\begin{array}{l}\text { Unit: exit point } \\
\text { [IEEE-982.1-1988] }\end{array}$ \\
\hline $\begin{array}{l}\text { Number of entries } \\
\text { and exits }\end{array}$ & $m_{i}$ & $=e_{i}+x_{i} \quad 9$ & $\begin{array}{l}\text { Unit: statement } \\
\text { [IEEE-982.1-1988] }\end{array}$ \\
\hline Defect density & & $\frac{\text { Number of known defects }}{\text { Product size }}$ & $\begin{array}{l}\text { Unit: defect/entity, } \\
\text { where entity may be } \\
\text { e.g. LOC, class, } \\
\text { module, function point, } \\
\text { etc. } \\
\text { [Fenton, p. 450] }\end{array}$ \\
\hline Depth of nesting & & $\begin{array}{l}\text { Number of loop statements, conditional } \\
\text { statements, and scoping blocks within } \\
\text { which a statement is enclosed. }\end{array}$ & $\begin{array}{l}\text { Unit: statement } \\
\text { [Conte, p. } 75]\end{array}$ \\
\hline $\begin{array}{l}\text { Span, } \\
\text { Reference span }\end{array}$ & & $\begin{array}{l}\text { "Number of statements between two } \\
\text { textual references to the same identifier." }\end{array}$ & $\begin{array}{l}\text { Unit: statement } \\
\text { [Elshoff] }\end{array}$ \\
\hline Locality of data & LD & $\begin{array}{l}\text { Proportion of variables accessed by a } \\
\text { class or module that are local to that class } \\
\text { or module, "excluding all trivial } \\
\text { read/write methods for instance } \\
\text { variables." } \\
\text { Generalized from object-oriented } \\
\text { definition. [Hitz] defines "local" as } \\
\text { "non-public instance variables of class C, } \\
\text { inherited protected instance variables of } \\
\text { its superclasses, and static variables } \\
\text { defined locally" in the methods. }\end{array}$ & $\begin{array}{l}\text { Unit: variable/variable } \\
\text { [Hitz] }\end{array}$ \\
\hline
\end{tabular}

\subsection{Belady and Evangelisti clustering complexity metric}

The first two equations have been rearranged for clarity. 


\begin{tabular}{|c|c|c|c|}
\hline Names & Symbols & Definitions & References \\
\hline $\begin{array}{l}\text { Total } \\
\text { complexity }\end{array}$ & $\mathrm{C}$ & $\begin{array}{l}=N E_{0}+\sum_{j=1}^{K} n_{j} e_{j} \\
\text { where } \\
\mathrm{K}=\text { number of clusters (packages) } \\
\mathrm{N}=\text { number of nodes (modules) } \\
\mathrm{n}_{\mathrm{j}}=\text { number of nodes in } j \text { th cluster } \\
\mathrm{e}_{\mathrm{j}}=\text { number of intracluster edges } \\
\text { (relationships) in } j \text { th cluster } \\
\mathrm{E}_{0}=\text { number of intercluster edges }\end{array}$ & $\begin{array}{l}\text { Unit: module } \cdot \text { relationship } \\
\text { [Belady] }\end{array}$ \\
\hline $\begin{array}{l}\text { Normalized } \\
\text { complexity }\end{array}$ & $\bar{C}$ & $\begin{array}{l}=\frac{C}{N E}=\frac{E_{0}}{E}+\sum_{j=1}^{K}\left(\frac{n_{j}}{N}\right)\left(\frac{e_{j}}{E}\right) \\
(* \text { Corrected apparent typo in [Belady] } \\
\text { where } \mathrm{e}_{j} \text { was normalized by N instead } \\
\text { of E.) }\end{array}$ & $\begin{array}{l}\text { Unit: }(\text { module } \cdot \text { relationship }) / \\
\text { (module } \cdot \text { relationship) } \\
\text { [Belady] }\end{array}$ \\
\hline $\begin{array}{l}\text { Approximate } \\
\text { complexity }\end{array}$ & $\tilde{C}$ & $\begin{array}{l}\text { Substituting } \mathrm{n}_{\mathrm{j}}=\mathrm{N} / \mathrm{K} \text { in } \bar{C} \text { produces } \\
\tilde{C}=\frac{1}{K} \frac{E_{i}}{E}+\frac{E_{0}}{E} \\
\text { where } E_{\mathrm{i}}=\text { total number (over all } \\
\text { clusters) of intracluster edges }\end{array}$ & $\begin{array}{l}\text { Unit: }(\text { module } \cdot \text { relationship } / \\
\text { (module } \cdot \text { relationship) } \\
\text { [Belady] }\end{array}$ \\
\hline
\end{tabular}

\subsection{Henry and Kafura information flow complexity metric}

\begin{tabular}{|l|l|l|l|}
\hline Names & Symbols & Definitions & References \\
\hline $\begin{array}{l}\text { Information flow } \\
\text { complexity }\end{array}$ & IFC & $\begin{array}{l}\text { (Of a procedure) } \\
\text { = (fan-in } \text { fan-out) } \\
\text { "The complexity of a module is defined to be } \\
\text { the sum of the complexities of the procedures } \\
\text { within the module." }\end{array}$ & $\begin{array}{l}\text { Unit: (data flow) } \\
\text { or ordinal } \\
\text { [Henry] }\end{array}$ \\
\hline $\begin{array}{l}\text { Weighted } \\
\text { information flow } \\
\text { complexity }\end{array}$ & $\begin{array}{l}\text { Weighted } \\
\text { IFC }\end{array}$ & $\begin{array}{l}\text { (Of a procedure) } \\
=\text { LOC } \cdot(\text { fan-in } \cdot \text { fan-out })^{2} \\
\text { "This measure includes imbedded comments } \\
\text { but does not include comments preceding the } \\
\text { procedure statement." }\end{array}$ & $\begin{array}{l}\text { Ordinal } \\
\text { [Henry] }\end{array}$ \\
\hline
\end{tabular}




\subsection{Cruickshank and Gaffney coupling metric}

\begin{tabular}{|l|l|l|l|}
\hline Names & Symbols & Definitions & References \\
\hline Coupling & $\begin{array}{l}\sum_{i=1}^{n} Z_{i} \\
n\end{array}$ & $\begin{array}{l}\text { Unit: data item } \\
\text { [IR5459, p. 19] } \\
\text { where } \\
Z_{i}=\frac{\sum_{j=1}^{m} M_{j}}{m} \\
\begin{array}{l}M_{j}=\text { sum of the number of input and output items shared } \\
\text { between components } i \text { and } j \\
Z_{i}=\text { average number of input and output items shared } \\
\text { [Cruickshank] } \\
n=\text { number of components in the software product } \\
\end{array}\end{array}$ & \\
\hline
\end{tabular}

\subsection{Structured Design scales of coupling and cohesion}

The ordinal scale of cohesion that was called binding in [StevensWP] evolved, grew, and was forked into two different scales for the same measurand. Versions of both resulting scales are provided in consecutive rows below.

\begin{tabular}{|c|c|c|c|}
\hline Names & Symbols & Definitions & References \\
\hline $\begin{array}{l}\text { Binding, } \\
\text { Module } \\
\text { cohesion }\end{array}$ & & $\begin{array}{l}\text { From most cohesive (best) to least cohesive (worst), with } \\
\text { "magic," "artificial values" from [Yourdon, p. 136]: } \\
\text { - Functional = 10: "every element of processing is an } \\
\text { integral part of, and is essential to, the performance of a } \\
\text { single function" } \\
\text { - Sequential = 9: "the output data (or results) from one } \\
\text { processing element serve as input data for the next } \\
\text { processing element" } \\
\text { - Communicational = 7: "all of the elements operate upon } \\
\text { the same input data set and/or produce the same output } \\
\text { data" } \\
\text { - Procedural = 5: elements of a module are "elements of a } \\
\text { common procedural unit" } \\
\text { Temporal = 3: "all occurrences of all elements of } \\
\text { processing in a collection occur within the same limited } \\
\text { period of time during the execution of the system" (such as } \\
\text { a start-up module) } \\
\text { Logical = 1: elements of a module fall into the same } \\
\text { logical class of similar or related functions } \\
\text { Coincidental = 0: "little or no constructive relationship } \\
\text { among the elements of a module" }\end{array}$ & $\begin{array}{l}\text { Ordinal } \\
\text { [Yourdon] }\end{array}$ \\
\hline
\end{tabular}




\begin{tabular}{|c|c|c|c|}
\hline Names & Symbols & Definitions & References \\
\hline $\begin{array}{l}\text { Module } \\
\text { strength, } \\
\text { Module } \\
\text { cohesion }\end{array}$ & & $\begin{array}{l}\text { From most cohesive (best) to least cohesive (worst): } \\
\text { - Functional: "performs a single specific function," and/or } \\
\text { Informational: "1. It contains multiple entry points. } 2 \text {. } \\
\text { Each entry point performs a single specific function. 3. All } \\
\text { of the functions are related by a concept, data structure, or } \\
\text { resource that is hidden within the module. 4. There are no } \\
\text { control-flow connections among the logic for each } \\
\text { function." } \\
\text { - Communicational: "performs multiple sequential } \\
\text { functions, where the sequential relationship among all of } \\
\text { the functions is implied by the problem or application } \\
\text { statement, and where there is a data relationship among all } \\
\text { of the functions" } \\
\text { - Procedural: "performs multiple sequential functions, where } \\
\text { the sequential relationship among all of the functions is } \\
\text { implied by the problem or application statement" } \\
\text { - Classical: "performs multiple sequential functions where } \\
\text { there is a weak, but nonzero, relationship among all of the } \\
\text { functions" } \\
\text { - Logical: "performs a set of related functions, one of which } \\
\text { is explicitly selected by the calling module" } \\
\text { - Coincidental: a module whose function cannot be defined } \\
\text { or that performs multiple, completely unrelated functions }\end{array}$ & $\begin{array}{l}\text { Ordinal } \\
\text { [MyersSD] }\end{array}$ \\
\hline $\begin{array}{l}\text { Module } \\
\text { coupling }\end{array}$ & & $\begin{array}{l}\text { From least coupling (best) to most coupling (worst): } \\
\text { - No direct coupling: none of the below } \\
\text { - Data: the modules directly communicate and use only } \\
\text { "homogenous data items"* to do so } \\
\text { - Stamp: "reference the same nonglobal data structure" } \\
\text { - Control: "one module explicitly controls the logic of the } \\
\text { other" } \\
\text { - External: reference a "homogenous global data item"* } \\
\text { - Common: reference a global data structure like a Fortran } \\
\text { - blank common block } \\
\text { - Content: one directly references the internals of the other } \\
\text { * Typical modern variables that are consistently, } \\
\text { unambiguously named and typed when referenced in different } \\
\text { modules would be considered "homogenous." }\end{array}$ & $\begin{array}{l}\text { Ordinal } \\
\text { [MyersSD] }\end{array}$ \\
\hline
\end{tabular}




\subsection{Embley and Woodfield scales of coupling and cohesion}

The metrics of [Embley] follow in the footsteps of the previous section, but are applied to abstract data types (ADTs) rather than modules.

\begin{tabular}{|c|c|c|c|}
\hline Names & Symbols & Definitions & References \\
\hline $\begin{array}{l}\text { (ADT) } \\
\text { Cohesion, } \\
\text { Strength }\end{array}$ & & $\begin{array}{l}\text { From most cohesive (best) to least cohesive (worst): } \\
\text { - Model: "1. logically exports one and only one domain D, } \\
\text { 2. logically exports only operations that apply to D and } \\
\text { should not be delegated to other ADTs, and 3. does not } \\
\text { contain a concealed ADT" } \\
\text { - Concealed: "does not have non-delegation, multifaceted, } \\
\text { or separable strength and it logically contains a hidden } \\
\text { ADT" } \\
\text { - Non-delegation: "does not have multifaceted or separable } \\
\text { strength and it includes an operator that should logically } \\
\text { be delegated to a more-primitive ADT" } \\
\text { Multifaceted: "does not have separable strength and it } \\
\text { logically exports two or more domains" } \\
\text { Separable: "if any one of the following conditions holds: } \\
\text { 1. There exists a logically-exported operator p of A such } \\
\text { that p does not utilize any logically-exported domain of A. } \\
\text { 2. A has two or more logically-exported domains, at least } \\
\text { one of which is not utilized by any operator of A. 3. A } \\
\text { has two or more logically-exported domains D1, D2,..., } \\
\text { Dn and the operators of A can be partitioned into n blocks } \\
\text { such that the operators in block i, } 1 \leq \mathrm{i} \leq \mathrm{n}, \text { utilize Di and } \\
\text { only Di" }\end{array}$ & $\begin{array}{l}\text { Ordinal } \\
\text { [Embley] }\end{array}$ \\
\hline $\begin{array}{l}\text { (ADT) } \\
\text { Coupling }\end{array}$ & & $\begin{array}{l}\text { From least coupling (best) to most coupling (worst): } \\
\text { - Export: "1. no function of A1 accesses the } \\
\text { implementation of A2 and 2. no function of A1 makes any } \\
\text { assumption about the implementation of A2" } \\
\text { - Surreptitious: "(A1,A2) does not have visible coupling, } \\
\text { but A1 uses knowledge about the implementation of A2" } \\
\text { - Visible: "A1 accesses the implementation of A2" }\end{array}$ & $\begin{array}{l}\text { Ordinal } \\
\text { [Embley] }\end{array}$ \\
\hline
\end{tabular}

\subsection{Briand, Morasca, and Basili metrics}

Model:

\begin{tabular}{|l|l|l|}
\hline Symbols & Definitions & References \\
\hline CI(c) & For a module or class $c$, the set of all CIs. & [Briand98] \\
\hline Max(c) & The set of all possible or potential CIs (combinatorically). & [Briand98] \\
\hline
\end{tabular}




\begin{tabular}{|l|l|l|}
\hline Symbols & Definitions & References \\
\hline $\mathrm{K}(\mathrm{c})$ & The set of CIs that are known to exist. & [Briand98] \\
\hline $\mathrm{U}(\mathrm{c})$ & The set of CIs whose existence or non-existence is unknown. & [Briand98] \\
\hline Global(m) & $\begin{array}{l}\text { "The set of all the external data declarations imported by a } \\
\text { module } m . "\end{array}$ & [Briand93] \\
\hline Local(m) & $\begin{array}{l}\text { "The set of all the locally defined data declarations in } \\
\text { module } m . "\end{array}$ & [Briand93] \\
\hline Scope(m) & $\begin{array}{l}\text { "The set of all data declarations declared outside the module } \\
\text { for which the internal data declarations of module } m \text { are } \\
\text { visible." }\end{array}$ & [Briand93] \\
\hline DD-interactions(m,n) & Number of DD-interactions between $m$ and $n$. & [Briand93] \\
\hline
\end{tabular}

\section{Metrics:}

\begin{tabular}{|l|l|l|l|}
\hline Names & Symbols & Definitions & References \\
\hline $\begin{array}{l}\text { Ratio of } \\
\text { cohesive } \\
\text { interactions }\end{array}$ & RCI & $R C I(c)=\frac{|C I(c)|}{|M a x(c)|}$ & $\begin{array}{l}\text { Unit: CI/CI } \\
\text { [Briand98] }\end{array}$ \\
\hline $\begin{array}{l}\text { Neutral ratio of } \\
\text { cohesive } \\
\text { interactions }\end{array}$ & NRCI & $N R C I(c)=\frac{|K(c)|}{|\operatorname{Max}(c)|-|U(c)|}$ & $\begin{array}{l}\text { Unit: CI/CI } \\
\text { [Briand98] }\end{array}$ \\
$\begin{array}{l}\text { Pessimistic } \\
\text { ratio of } \\
\text { cohesive } \\
\text { interactions }\end{array}$ & PRCI & $P R C I(c)=\frac{|K(c)|}{|\operatorname{Max}(c)|}$ & $\begin{array}{l}\text { Unit: CI/CI } \\
\text { [Briand98] }\end{array}$ \\
\hline $\begin{array}{l}\text { Optimistic ratio } \\
\text { of cohesive } \\
\text { interactions }\end{array}$ & ORCI & ORCI(c) $=\frac{|K(c)|+|U(c)|}{|M a x(c)|}$ & $\begin{array}{l}\text { Unit: CI/CI } \\
\text { [Briand98] }\end{array}$ \\
\hline $\begin{array}{l}\text { Import } \\
\text { coupling }\end{array}$ & IC & $\begin{array}{l}\text { IC(m) }=\text { DD-interactions(Global(m), } \\
\text { Local(m)) } \\
\text { (Including both direct and transitive } \\
\text { interactions.) } \\
\text { For generic modules: "The import coupling } \\
\text { of a generic module is the cardinality of the } \\
\text { union of the sets of DD-interactions between } \\
\text { the data declarations in the software system } \\
\text { and those of each of its instances." } \\
\text { [Briand94, p. 20] }\end{array}$ & \\
\hline
\end{tabular}




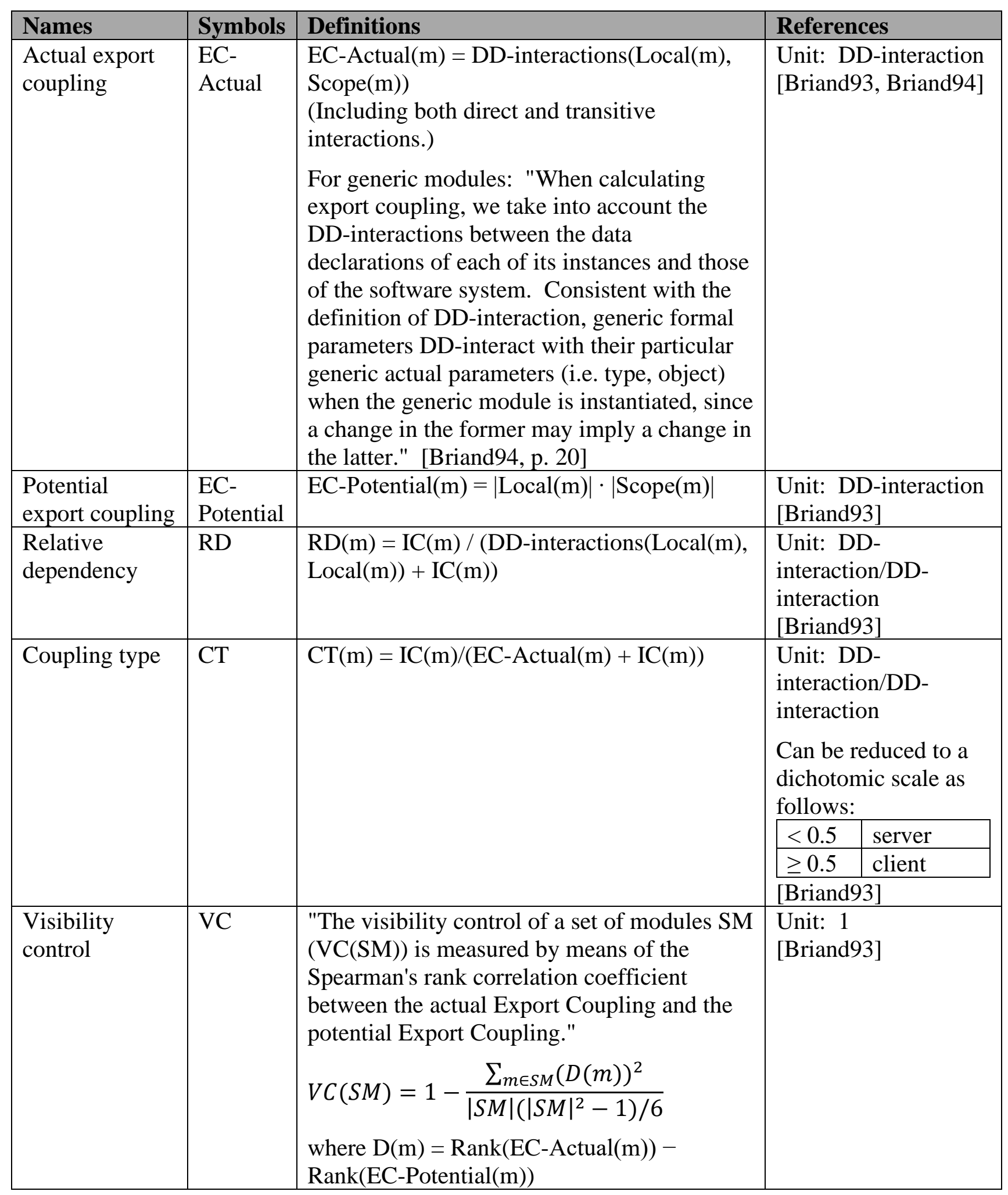

\subsection{Halstead system}

Defined input quantities: 


\begin{tabular}{|l|l|l|l|}
\hline Names & Symbols & Definitions & References \\
\hline $\begin{array}{l}\text { Stroud } \\
\text { number }\end{array}$ & $\mathrm{S}$ & $\begin{array}{l}\text { 18 } \\
\text { Halstead consistently sets S = 18 "elementary } \\
\text { discriminations" per second. This value came from } \\
\text { [Halstead], not [Stroud]. }\end{array}$ & $\begin{array}{l}\text { Unit: operation/s } \\
\text { [Halstead] }\end{array}$ \\
\hline $\begin{array}{l}\text { Unique } \\
\text { operator } \\
\text { count }\end{array}$ & $\eta_{1}$ & $\begin{array}{l}\text { "Number of unique or distinct operators" appearing } \\
\text { in an implementation. Secondary sources may } \\
\text { replace the Greek } \eta \text { with n [Abran p. 146] or even } \mu \\
\text { [Fenton p. 345]. }\end{array}$ & $\begin{array}{l}\text { Unit: operator } \\
\text { [Halstead pp. 2, 6] }\end{array}$ \\
\hline $\begin{array}{l}\text { Total } \\
\text { operators }\end{array}$ & $\mathrm{N}_{1}$ & $\begin{array}{l}\text { "Total usage of all of the operators" appearing in an } \\
\text { implementation. }\end{array}$ & $\begin{array}{l}\text { Unit: operator } \\
\text { [Halstead pp. 2, 6] }\end{array}$ \\
\hline $\begin{array}{l}\text { Unique } \\
\text { operand } \\
\text { count }\end{array}$ & $\eta_{2}$ & $\begin{array}{l}\text { "Number of unique or distinct operands" appearing } \\
\text { in an implementation. Secondary sources may } \\
\text { replace the Greek } \eta \text { with n [Abran p. 146] or even } \mu \\
\text { [Fenton p. 345]. }\end{array}$ & $\begin{array}{l}\text { Unit: operand } \\
\text { [Halstead pp. 2, 6] }\end{array}$ \\
\hline $\begin{array}{l}\text { Total } \\
\text { operands }\end{array}$ & $\mathrm{N}_{2}$ & $\begin{array}{l}\text { "Total usage of all of the operands" appearing in an } \\
\text { implementation. }\end{array}$ & $\begin{array}{l}\text { Unit: operand } \\
\text { [Halstead pp. 2, 6] }\end{array}$ \\
\hline $\begin{array}{l}\text { Potential } \\
\text { operand } \\
\text { count }\end{array}$ & $\eta_{2}{ }^{*}$ & $\begin{array}{l}\text { "Number of conceptually unique operands" } \\
\text { [Halstead pp. 20, 28] }\end{array}$ \\
\hline
\end{tabular}

The following is not an exhaustive list of Halstead's measures, but includes those that are used as input quantities by other metrics in this document.

Chapter 8 of [Halstead] reinterpreted several quantities to refer to mental operations instead of bits. To avoid confusion, these should have been defined as new quantities that were just numerically equal to the previous ones when expressed in incompatible units.

\begin{tabular}{|l|l|l|l|}
\hline Names & Symbols & Definitions & References \\
\hline $\begin{array}{l}\text { Vocabulary } \\
\text { size }\end{array}$ & $\eta$ & $\eta_{1}+\eta_{2}$ & $\begin{array}{l}\text { Unit: token } \\
\text { [Halstead p. 2] }\end{array}$ \\
\hline $\begin{array}{l}\text { Potential } \\
\text { vocabulary }\end{array}$ & $\eta^{*}$ & $2+\eta_{2}{ }^{*}$ & $\begin{array}{l}\text { Unit: token } \\
\text { [Halstead p. 2] }\end{array}$ \\
\hline Program length & $\mathrm{N}$ & $\mathrm{N}_{1}+\mathrm{N}_{2}$ & $\begin{array}{l}\text { Unit: token } \\
\text { [Halstead p. 2] }\end{array}$ \\
\hline $\begin{array}{l}\text { Program } \\
\text { volume }\end{array}$ & $\mathrm{V}$ & $\mathrm{N} \log _{2} \eta$ & $\begin{array}{l}\text { Unit: bit } \\
\text { [Halstead p. 2] } \\
\text { "Mental comparisons" } \\
\text { [Halstead pp. 46-47] }\end{array}$ \\
\hline
\end{tabular}




\begin{tabular}{|c|c|c|c|}
\hline Names & Symbols & Definitions & References \\
\hline $\begin{array}{l}\text { Potential } \\
\text { volume }\end{array}$ & $\mathrm{V}^{*}$ & $\begin{array}{l}\eta^{*} \log _{2} \eta^{*} \\
\text { Halstead uses "potential" in the sense of } \\
\text { hypothetical ideal or optimal value; e.g., } \\
\text { "the most succinct form in which an } \\
\text { algorithm could ever be expressed" in any } \\
\text { programming language that one might } \\
\text { construct. }\end{array}$ & $\begin{array}{l}\text { Unit: bit } \\
\text { [Halstead p. 2] }\end{array}$ \\
\hline Effort & $\mathrm{E}$ & $\mathrm{V} / \mathrm{L}=\mathrm{V}^{2} / \mathrm{V}^{*}=\mathrm{D} \cdot \mathrm{V}$ & $\begin{array}{l}\text { Unit: bit } \\
\text { [Halstead p. 2] } \\
\text { "Elementary mental } \\
\text { discriminations" } \\
\text { [Halstead p. 47] }\end{array}$ \\
\hline $\begin{array}{l}\text { [Estimated] } \\
\text { implementation } \\
\text { time }\end{array}$ & $\begin{array}{l}\mathrm{T}, \\
\hat{T}\end{array}$ & $\begin{array}{l}\frac{E}{S} \\
\text { Where } S \text { is the Stroud number defined } \\
\text { above. }\end{array}$ & $\begin{array}{l}\text { Unit: s } \\
\text { (Assuming } 1 \\
\text { "elementary } \\
\text { discrimination" = } 1 \text { bit) } \\
{[\text { Halstead pp. 2, 48, 52] }}\end{array}$ \\
\hline Program level & $\mathrm{L}$ & $\begin{array}{l}\mathrm{V}^{*} / \mathrm{V} \\
\text { [Halstead p. 47] reinterprets } \mathrm{L} \text { as a ratio of } \\
\text { "mental comparisons" to "elementary } \\
\text { mental discriminations." This is difficult to } \\
\text { reconcile. }\end{array}$ & $\begin{array}{l}\text { Unit: bit/bit } \\
\text { [Halstead p. 2] }\end{array}$ \\
\hline Difficulty & $\mathrm{D}$ & $1 / \mathrm{L}$ & $\begin{array}{l}\text { Unit: bit/bit } \\
\text { [Halstead p. 2] }\end{array}$ \\
\hline $\begin{array}{l}\text { Approximated } \\
\text { program level }\end{array}$ & $\widehat{L}$ & $\frac{2}{\eta_{1}} \frac{\eta_{2}}{N_{2}}$ & $\begin{array}{l}\text { Unit: (token/token) }{ }^{2} \\
\text { [Halstead pp. 2, 27] }\end{array}$ \\
\hline
\end{tabular}

\subsection{Functional size (of a software application)}

Functional size is generically defined in [ISO-FSM] as "size of the software derived by quantifying the Functional User Requirements." There are multiple standards for how this is determined. The details of these quantities have been elided; please refer to the relevant standards.

\begin{tabular}{|l|l|l|l|}
\hline \multicolumn{1}{|c|}{ Names } & Symbols & \multicolumn{1}{|c|}{ Definitions } & \multicolumn{1}{c|}{ References } \\
\hline $\begin{array}{l}\text { Application } \\
\text { function } \\
\text { point count }\end{array}$ & AFP & $\begin{array}{l}\text { Sum of the functional sizes of all BFCs (see Sec. 2.6). } \\
\text { The functional size of a BFC is a table-driven function } \\
\text { of the numbers of RETs or FTRs (for data and } \\
\text { transactional functions respectively) and DETs, and of } \\
\text { the function type. }\end{array}$ & $\begin{array}{l}\text { FP (ordinal) } \\
\text { [ISO-IFPUG] }\end{array}$ \\
\hline $\begin{array}{l}\text { [ISO-NESMA] } \\
\text { function } \\
\text { point size }\end{array}$ & AFPs & $\begin{array}{l}\text { Variant of ibid. in which the input quantities are } \\
\text { determined automatically from source code and other } \\
\text { artifacts. }\end{array}$ & $\begin{array}{l}\text { AFP (ordinal) } \\
\text { [AFP] }\end{array}$ \\
\hline
\end{tabular}




\begin{tabular}{|l|l|l|l|}
\hline \multicolumn{1}{|c|}{ Names } & Symbols & \multicolumn{1}{c|}{ Definitions } & \multicolumn{1}{c|}{ References } \\
\hline $\begin{array}{l}\text { COSMIC } \\
\text { functional } \\
\text { size }\end{array}$ & FS & $\begin{array}{l}\text { Sum of the functional sizes of all BFCs. The } \\
\text { functional size (FS) of a BFC is the number of data } \\
\text { movements (entries, exits, reads, and writes). }\end{array}$ & $\begin{array}{l}\text { CFP } \\
\text { [ISO-COSMIC] }\end{array}$ \\
\hline $\begin{array}{l}\text { FiSMA } \\
\text { functional } \\
\text { size }\end{array}$ & S & $\begin{array}{l}\text { Sum of the functional sizes of all BFCs. The } \\
\text { functional size of a BFC is a function of the numbers of } \\
\text { DETs, reading references, writing references, and } \\
\text { operations, and of the BFC type. }\end{array}$ & $\begin{array}{l}\text { Ffp (ordinal) } \\
\text { [ISO-FiSMA] }\end{array}$ \\
\hline $\begin{array}{l}\text { MkII } \\
\text { functional } \\
\text { size }\end{array}$ & FS & $\begin{array}{l}\text { "The weighted sum over all Logical Transactions, of } \\
\text { the Input Data Element Types (Ni), the Data Entity } \\
\text { Types Referenced (Ne), and the Output Data Element } \\
\text { Types (No)." } \\
=0.58 \text { Ni + 1.66 Ne + 0.26 No } 4\end{array}$ & $\begin{array}{l}\text { MkII FP } \\
\text { (ordinal) } \\
\text { [ISO-MkII] }\end{array}$ \\
\hline
\end{tabular}

\subsection{Card and Glass complexity metrics}

Defined input quantities:

\begin{tabular}{|l|l|l|l|}
\hline Names & Symbols & Definitions & References \\
\hline & $n$ & The number of modules in the system. & $\begin{array}{l}\text { Unit: module } \\
\text { [Card, Ch. 5] }\end{array}$ \\
\hline $\mathrm{f}(\mathrm{i})$ & $\begin{array}{l}\text { The fanout of module } i . \\
\text { "The fanout count defined here does not include calls to } \\
\text { system or standard utility routines, but does include calls to } \\
\text { modules reused from other application programs." }\end{array}$ & $\begin{array}{l}\text { Unit: call } \\
\text { [Card, Ch. 5] }\end{array}$ \\
\hline $\mathrm{v}(\mathrm{i})$ & $\begin{array}{l}\text { The number of input/output (I/O) variables in module } i . \\
\text { I/O variables means "distinct arguments in a calling sequence } \\
\text { (an array counts as one variable) as well as referenced } \\
\text { COMMON variables." }\end{array}$ & $\begin{array}{l}\text { Unit: variable } \\
\text { [Card, Ch. 5] }\end{array}$ \\
\hline
\end{tabular}

Metrics:

\begin{tabular}{|l|l|l|l|}
\hline Names & Symbols & Definitions & References \\
\hline $\begin{array}{l}\text { System } \\
\text { complexity } \\
\text { (overall) }\end{array}$ & $\mathrm{Ct}$ & $\mathrm{Ct}=\mathrm{St}+\mathrm{Dt}$ & $\begin{array}{l}\text { Ordinal } \\
\text { [Card, Eqn. 5-1] }\end{array}$ \\
\hline $\begin{array}{l}\text { Structural } \\
\text { (intermodule) } \\
\text { complexity }\end{array}$ & $\mathrm{St}$ & Inferred from Eqn. 5-2 and 5-3 that $S t=\sum f^{2}(i)$ & $\begin{array}{l}\text { Unit: call }{ }^{2} \\
\text { [Card, Ch. 5] }\end{array}$ \\
\hline $\begin{array}{l}\text { Data } \\
\text { (intramodule) } \\
\text { complexity }\end{array}$ & $\mathrm{Dt}$ & Inferred from Eqn. 5-2 and 5-4 that $D t=\sum\left\{\frac{v(i)}{[f(i)+1]}\right\}$ & $\begin{array}{l}\text { Unit: } \\
\text { variable/call } \\
\text { [Card, Ch. 5] }\end{array}$ \\
\hline $\begin{array}{l}\text { Relative } \\
\text { system } \\
\text { complexity }\end{array}$ & $\mathrm{C}$ & $\mathrm{C}=\frac{C t}{n}=\frac{S t}{n}+\frac{D t}{n}$ & $\begin{array}{l}\text { Ordinal } \\
\text { [Card, Eqn. 5-2] }\end{array}$ \\
\hline
\end{tabular}




\begin{tabular}{|l|l|l|l|}
\hline Names & Symbols & Definitions & References \\
\hline $\begin{array}{l}\text { [Relative] } \\
\text { structural } \\
\text { intermodule) } \\
\text { complexity }\end{array}$ & $\mathrm{S}$ & $S=\frac{\sum f^{2}(i)}{n}$ & $\begin{array}{l}\text { Unit: } \\
\text { call }^{2} / \text { module } \\
\text { [Card, Eqn. 5-3] }\end{array}$ \\
\hline $\begin{array}{l}\text { Data } \\
\text { complexity } \\
\text { [of a module] }\end{array}$ & $\mathrm{D}(i)$ & $D(i)=\frac{V(i)}{f(i)+1}$ & $\begin{array}{l}\text { Unit: } \\
\text { variable/call } \\
\text { [Card, Ch. 5] } \\
\text { unnumbered } \\
\text { equation }\end{array}$ \\
\hline $\begin{array}{l}\text { [Relative] } \\
\text { data } \\
\text { (intramodule) } \\
\text { complexity }\end{array}$ & $\mathrm{D}$ & $\frac{\sum\left\{\frac{v(i)}{[f(i)+1]}\right.}{n}$ & $\begin{array}{l}\text { Unit: } \\
\text { (variable/call) } \\
\text { /module } \\
\text { [Card, Eqn. 5-4] }\end{array}$ \\
\hline
\end{tabular}

\subsection{Program Complexity Analysis Methodology (PCAM) metrics}

The following tables are based primarily on [McClure1]. The definitions in [McClure2] are mostly equivalent, just using different symbols. However, there are a few substantive differences:

- $\quad$ McClure2] contains a more elaborate definition of module complexity (M) that addresses abort routines. The input quantity $Z_{m}$ is used only by the [McClure2] definition.

- Both references assert that the complexity of each module should be minimized and that the complexity among modules in a well-structured program should be evenly distributed. However, an example in which these criteria are tested using the mean module complexity and the maximum deviation from that mean appears only in [McClure2, p. 119]. [McClure1], in contrast, proceeds to define partitioning scheme complexity (PS) as the sum of module complexities.

Defined inputs:

\begin{tabular}{|c|c|c|c|}
\hline Names & Symbols & Definitions & References \\
\hline & $\mathrm{P}$ & $\begin{array}{l}=\left\{\mathrm{p}_{1}, \ldots, \mathrm{p}_{\mathrm{n}}\right\} \text { is the set of modules defined in the } \\
\text { design of a well-structured program }\end{array}$ & [McClure1] \\
\hline & $\gamma$ & The root module & [McClure1] \\
\hline & $\mathrm{f}$ & $\mathrm{f}: \mathrm{P} \rightarrow \mathrm{X}$ is the invoking function such that $\mathrm{X} \subset \mathrm{P}$ & [McClure1] \\
\hline \multirow[t]{3}{*}{$\begin{array}{l}\text { Program control } \\
\text { hierarchical system }\end{array}$} & PCHS & The triple $(\mathrm{P}, \gamma, \mathrm{f})$ & [McClure1] \\
\hline & $\mathrm{n}$ & Number of unique modules in the PCHS & [McClure1] \\
\hline & $\mathrm{s}$ & Total number of control variables & [McClure1] \\
\hline $\begin{array}{l}\text { Invocation control } \\
\text { variable set }\end{array}$ & & $\begin{array}{l}\text { Set of control variables upon whose values a } \\
\text { particular invocation of a module depends }\end{array}$ & [McClure1] \\
\hline \multirow[t]{2}{*}{$\begin{array}{l}\text { Branch control } \\
\text { variable set }\end{array}$} & & $\begin{array}{l}\text { Set of control variables upon whose values a branch } \\
\text { may be made to an abort routine }\end{array}$ & [McClure2] \\
\hline & $F_{p_{i}}$ & Set of direct ancestors of module $\mathrm{p}_{\mathrm{i}}$ & [McClure1] \\
\hline
\end{tabular}




\begin{tabular}{|c|c|c|c|}
\hline Names & Symbols & Definitions & References \\
\hline & $G_{p_{i}}$ & Set of direct descendants of module $\mathrm{p}_{\mathrm{i}}$ & [McClure1] \\
\hline & $H_{p_{i}}$ & Set of ancestors of module $\mathrm{p}_{\mathrm{i}}$ & [McClure1] \\
\hline & $L_{p_{i}}$ & Set of descendants of module $\mathrm{p}_{\mathrm{i}}$ & [McClure1] \\
\hline & $\mathrm{A}_{\mathrm{v}}$ & $\begin{array}{l}\text { Set of modules in which the value of control } \\
\text { variable } v \text { is accessed, }=M_{v} \cup R_{v}\end{array}$ & [McClure1] \\
\hline & $\mathrm{E}_{\mathrm{V}}$ & $\begin{array}{l}\text { Set of modules whose invocation is dependent upon } \\
\text { the value of control variable } v\end{array}$ & [McClure1] \\
\hline & $\mathrm{M}_{\mathrm{v}}$ & $\begin{array}{l}\text { Set of modules in which the value of control } \\
\text { variable } v \text { is modified }\end{array}$ & [McClure1] \\
\hline & $\mathrm{R}_{\mathrm{v}}$ & $\begin{array}{l}\text { Set of modules in which the value of control } \\
\text { variable } v \text { is strictly referenced (i.e., referenced but } \\
\text { not modified) }\end{array}$ & [McClure1] \\
\hline & $\mathrm{T}_{\mathrm{V}}$ & $\begin{array}{l}=\left\{p_{j} \mid p_{j} \in A_{v} \wedge \exists p_{k} \in F_{p_{j}} \ni p_{k} \notin A_{v}\right\} \\
\text { (The symbol } \ni \text { after an existential denotes "such } \\
\text { that.") }\end{array}$ & [McClure1] \\
\hline & $\mathrm{U}_{\mathrm{v}}$ & $=\left\{p_{j} \mid p_{j} \in R_{v} \wedge \exists p_{k} \in L_{p_{j}} \ni p_{k} \in M_{v}\right\}$ & [McClure1] \\
\hline & $\mathrm{W}_{\mathrm{v}}$ & $\begin{array}{l}=\left\{p_{i} \mid p_{i} \in A_{v} \wedge \exists p_{j} \in M_{v} \ni p_{j} \notin H_{p_{j}}\right. \\
\left.\text { and } p_{j} \text { is listed above } p_{i} \text { in the PCHS structure }\right\}\end{array}$ & [McClure1] \\
\hline Owner module & $\alpha_{\mathrm{v}}$ & $\begin{array}{l}\text { "Local root of the smallest PCHS subhierarchy } \\
\text { which contains all members of the set } A_{v} "\end{array}$ & [McClure1] \\
\hline $\begin{array}{l}\text { Degree of } \\
\text { ownership }\end{array}$ & $\mathrm{D}(\mathrm{v})$ & $\begin{array}{l}=1 \text { if the value of control variable } v \text { is modified } \\
\text { exclusively in } \alpha_{\mathrm{v}} \text { or never modified } \\
2 \text { if it is modified in } \alpha_{\mathrm{v}} \text { and in at least one } \\
\text { descendant of } \alpha_{\mathrm{v}} \\
3 \text { if it is strictly referenced in } \alpha_{\mathrm{v}} \text { and modified in at } \\
\text { least one descendant of } \alpha_{\mathrm{v}} \\
4 \text { if it is not accessed in } \alpha_{\mathrm{v}} \text { and is modified in at } \\
\text { least one descendant of } \alpha_{\mathrm{v}}\end{array}$ & [McClure1] \\
\hline
\end{tabular}

Quantities:

\begin{tabular}{|c|c|c|c|}
\hline Names & Symbols & Definitions & References \\
\hline $\begin{array}{l}\text { Interaction } \\
\text { complexity }\end{array}$ & $\mathrm{I}(\mathrm{v})$ & $\begin{array}{l}=\mathrm{q}_{\mathrm{v}}+\mathrm{u}_{\mathrm{v}}+\mathrm{w}_{\mathrm{v}}+\mathrm{t}_{\mathrm{v}} \\
\text { where } \\
\mathrm{q}_{\mathrm{v}}=\left|\mathrm{M}_{\mathrm{v}} \cap \mathrm{E}_{\mathrm{v}}\right| \\
\mathrm{u}_{\mathrm{v}}=\left|\mathrm{U}_{\mathrm{v}}\right| \\
\mathrm{w}_{\mathrm{v}}=\left|\mathrm{W}_{\mathrm{v}}\right| \\
\mathrm{t}_{\mathrm{v}}=\left|\mathrm{T}_{\mathrm{v}}\right|\end{array}$ & $\begin{array}{l}\text { Unit: module } \\
\text { [McClure1] }\end{array}$ \\
\hline $\begin{array}{l}\text { Control } \\
\text { variable } \\
\text { complexity }\end{array}$ & $\mathrm{C}(\mathrm{v})$ & $\mathrm{C}(\mathrm{v})=\mathrm{D}(\mathrm{v}) \cdot \mathrm{I}(\mathrm{v}) / \mathrm{n}$ & $\begin{array}{l}\text { Ordinal } \\
\text { Range: } 0 \leq \mathrm{C}(\mathrm{v})<8 \\
{[\text { McClure } 1]}\end{array}$ \\
\hline
\end{tabular}




\begin{tabular}{|c|c|c|c|}
\hline Names & Symbols & Definitions & References \\
\hline & $\mathrm{X}(\mathrm{p})$ & $\begin{array}{l}\text { If } \mathrm{x}=0, \mathrm{X}(\mathrm{p})=0 \text {; else, } \\
X(p)=\sum_{j=1}^{x} \frac{b_{j} \cdot \sum_{i=1}^{e} C\left(v_{j i}\right)}{x} \\
\text { where } \\
\mathrm{x}=\text { number of invocation control variable sets } \\
\text { used in the invocation of module } \mathrm{p} \\
\mathrm{e}=\text { number of control variables in the } \mathrm{j}^{\text {th }} \\
\text { invocation control variable set where } 1 \leq \mathrm{j} \leq \mathrm{x} \\
\mathrm{V}_{\mathrm{ji}}=\text { the } \mathrm{i}^{\text {th }} \text { control variable in the } \mathrm{j}^{\text {th }} \\
\text { invocation control variable set where } 1 \leq \mathrm{i} \leq \mathrm{e} \\
\mathrm{b}_{\mathrm{j}}=1 \text { if the } \mathrm{j}^{\text {th }} \text { invocation is within a selection } \\
\text { structure or a set of nested selection } \\
\text { structures, or } 2 \text { if the } \mathrm{j}^{\text {th }} \text { invocation is within a } \\
\text { repetition structure }\end{array}$ & $\begin{array}{l}\text { Ordinal } \\
\text { [McClure1] }\end{array}$ \\
\hline & $\mathrm{Y}(\mathrm{p})$ & $\begin{array}{l}\text { If } \mathrm{y}=0, \mathrm{Y}(\mathrm{p})=0 \text {; else, } \\
Y(p)=\sum_{j=1}^{y} \frac{b_{j} \cdot \sum_{i=1}^{k} C\left(v_{j i}\right)}{y} \\
\text { where } \\
\mathrm{y}=\text { number of invocation control variable sets } \\
\text { referenced by module } \mathrm{p} \text { to invoke its direct } \\
\text { descendants } \\
\mathrm{k}=\text { number of control variables in the } \mathrm{j}^{\text {th }} \\
\text { invocation control variable set where } 1 \leq \mathrm{j} \leq \mathrm{y} \\
\mathrm{v}_{\mathrm{ji}}=\text { the } \mathrm{i}^{\text {th }} \text { control variable in the } \mathrm{j}^{\text {th }} \\
\text { invocation control variable set for } 1 \leq \mathrm{i} \leq \mathrm{k} \\
\mathrm{b}_{\mathrm{j}}=1 \text { if the } \mathrm{j}^{\text {th }} \text { invocation is within a selection } \\
\text { structure or a set of nested selection } \\
\text { structures, or } 2 \text { if the } \mathrm{j}^{\text {th }} \text { invocation is within a } \\
\text { repetition structure }\end{array}$ & $\begin{array}{l}\text { Ordinal } \\
\text { [McClure1] }\end{array}$ \\
\hline & $\mathrm{Z}_{\mathrm{m}}$ & $\begin{array}{l}\text { If } \mathrm{z}=0, \mathrm{Z}_{\mathrm{m}}=0 \text {; else, } \\
Z_{m}=\frac{\sum_{j=1}^{z} \sum_{i=1}^{a} C\left(v_{j i}\right)}{Z} \\
\text { where } \\
\mathrm{z}=\text { number of branch control variable sets } \\
\text { used to branch from module } \mathrm{m} \text { to abort } \\
\text { routines } \\
\mathrm{a}=\text { number of control variables in the } \mathrm{j}^{\text {th }} \\
\text { branch control variable set where } 1 \leq \mathrm{j} \leq \mathrm{z} \\
\mathrm{v}_{\mathrm{ji}}=\text { the } \mathrm{i}^{\text {th }} \text { control variable in the } \mathrm{j}^{\text {th }} \text { branch } \\
\text { control variable set where } 1 \leq \mathrm{i} \leq \mathrm{a}\end{array}$ & $\begin{array}{l}\text { Ordinal } \\
\text { [McClure2] }\end{array}$ \\
\hline
\end{tabular}




\begin{tabular}{|l|l|l|l|}
\hline $\begin{array}{l}\text { Names } \\
\text { complexity }\end{array}$ & Symbols & $\begin{array}{l}\text { Definitions } \\
M(p)=f_{p} \cdot X(p)+g_{p} \cdot Y(p) \\
\text { where } \mathrm{f}_{\mathrm{p}}=\left|\mathrm{F}_{\mathrm{p}}\right| \text { and } \mathrm{g}_{\mathrm{p}}=\left|\mathrm{G}_{\mathrm{p}}\right| .\end{array}$ & $\begin{array}{l}\text { References } \\
\text { Ordinal } \\
\text { Range: } 0 \leq \mathrm{M}(\mathrm{p})<16 \mathrm{~s} \mathrm{n} \\
\text { [McClure1] } \\
\text { (See defined inputs } \\
\text { above for s and } \mathrm{n})\end{array}$ \\
\hline $\begin{array}{l}\text { Module } \\
\text { complexity }\end{array}$ & $\mathrm{M}(\mathrm{m})$ & $\begin{array}{l}\mathrm{M}(\mathrm{m})=\mathrm{T}_{1}+\mathrm{T}_{2}+\mathrm{T}_{3} \\
\text { where } \mathrm{T}_{1} \text { and } \mathrm{T}_{2} \text { are equivalent to the two } \\
\text { terms of } \mathrm{M}(\mathrm{p}) \text { above and } \\
\mathrm{T}_{3}=\mathrm{B}_{\mathrm{m}} \times \mathrm{Z}_{\mathrm{m}} \\
\text { where } \mathrm{B}_{\mathrm{m}} \text { is the number of abort routines to } \\
\text { which module m may branch. }\end{array}$ & $\begin{array}{l}\text { Ordinal } \\
\text { Range: } 0 \mathrm{M}(\mathrm{m})< \\
16 \mathrm{~s} \mathrm{n} \\
{[\text { McClure2] }}\end{array}$ \\
\hline $\begin{array}{l}\text { Partitioning } \\
\text { scheme } \\
\text { complexity }\end{array}$ & PS & $\begin{array}{l}\text { PS } \\
=\sum_{i=1}^{n} M\left(p_{i}\right)\end{array}$ & $\begin{array}{l}\text { Ordinal } \\
\text { [McClure1] }\end{array}$ \\
\hline
\end{tabular}

\subsection{Maintainability index}

The maintainability indices referenced by Software Engineering Institute (SEI) and Microsoft are derived from what has been called the Coleman-Oman model [Liso]. A survey of publications authored by Don Coleman, Paul Oman, and their associates between 1993 and 1997 (see list in Coleman-Oman maintainability model subsection following the Bibliography) revealed 13 different candidate definitions for this metric.

\begin{tabular}{|c|c|c|c|}
\hline Names & Symbols & Definitions & References \\
\hline $\begin{array}{l}\text { Maintainability } \\
\text { index (SEI } \\
\text { version) }\end{array}$ & $\mathrm{MI}$ & $\begin{array}{l}\begin{array}{r}171-5.2 \cdot \ln (\text { aveV })-0.23 \cdot \operatorname{aveV}(\mathrm{g}) \\
\qquad-16.2 \cdot \ln (\text { aveLOC }) \\
+50 \cdot \sin (\sqrt{2.4 \cdot \text { perCM}})\end{array} \\
\text { where } \\
\text { aveV = average Halstead V per module } \\
\text { aveV(g') = average extended cyclomatic } \\
\text { complexity per module } \\
\text { aveLOC = average LOC per module; } \\
\text { and, optionally, } \\
\text { perCM = average "percent"* of lines of } \\
\text { comments per module }(* \text { actually the } \\
\text { proportion aveCMT/aveLOC; see } \\
\text { footnote 2 in [Oman]) } \\
\text { In [Coleman], the input quantities were } \\
\text { averaged by submodule, defined as } \\
\text { "function or procedure." In the same } \\
\text { context, [Welker] wrote: "This paper }\end{array}$ & $\begin{array}{l}\text { Ordinal } \\
\text { [SEI] } \\
\text { [Welker, Eqn. 5] }\end{array}$ \\
\hline
\end{tabular}




\begin{tabular}{|c|c|c|c|c|}
\hline Names & Symbols & Definitions & \multicolumn{2}{|l|}{ References } \\
\hline & & $\begin{array}{l}\text { uses the term 'subroutine' or 'module' for } \\
\text { any named lexical component of a } \\
\text { program, which given a specific } \\
\text { programming language might be a } \\
\text { function, a procedure, a subroutine, a } \\
\text { section, a module, etc." }\end{array}$ & & \\
\hline \multirow[t]{5}{*}{$\begin{array}{l}\text { Maintainability } \\
\text { index } \\
\text { (Microsoft } \\
\text { version) }\end{array}$} & & \multirow{5}{*}{$\begin{array}{l}\max (0,(171-5.2 \cdot \ln (\mathrm{V})-0.23 \cdot \mathrm{V}(\mathrm{G}) \\
\left.\qquad-16.2 \cdot \ln (\mathrm{LOC})) \cdot \frac{100}{171}\right) \\
\text { The metric is calculated for each type or } \\
\text { method instead of using averages as } \\
\text { inputs. }\end{array}$} & \multicolumn{2}{|c|}{$\begin{array}{l}\text { Ordinal } \\
\text { Range: } 0 \text { to } 100 \\
\text { The scale is further } \\
\text { reduced to a 3-level } \\
\text { ordinal scale as follows: }\end{array}$} \\
\hline & & & 20 to 100 & $\begin{array}{l}\text { green/high/ } \\
\text { good }\end{array}$ \\
\hline & & & 10 to 19 & $\begin{array}{l}\text { yellow/ } \\
\text { moderate }\end{array}$ \\
\hline & & & 0 to 9 & red/low/bad \\
\hline & & & \multicolumn{2}{|l|}{ [Microsoft] } \\
\hline
\end{tabular}

\subsection{Maturity index}

\begin{tabular}{|c|c|c|c|}
\hline Names & Symbols & Definitions & References \\
\hline $\begin{array}{l}\text { Software } \\
\text { maturity } \\
\text { index }\end{array}$ & SMI & $\begin{array}{l}\text { [The available definition is equivocal } \\
\text { over whether the units to be counted are } \\
\text { functions or modules.] } \\
=\frac{M_{T}-\left(F_{a}+F_{c}+F_{d e l}\right)}{M_{T}} \\
\text { where } \\
M_{\mathrm{T}}=\text { number of software functions } \\
\text { (modules) in the current delivery } \\
\mathrm{F}_{\mathrm{C}}=\text { number of software functions } \\
\text { (modules) in the current delivery that } \\
\text { include internal changes from a previous } \\
\text { delivery } \\
F_{\mathrm{a}}=\text { number of software functions } \\
\text { (modules) in the current delivery that } \\
\text { are additions to the previous delivery } \\
\text { F }_{\text {del }} \text { number of software functions } \\
\text { (modules) in the previous delivery that } \\
\text { are deleted in the current delivery }{ }^{9}\end{array}$ & $\begin{array}{l}\text { Unit: function/function or } \\
\text { module/module } \\
\text { Range: }-\infty \text { to } 1 \\
\text { (Negative values due to large } F_{\text {del }} \\
\text { may have been unintentional) } \\
\text { [IEEE-982.1-1988] } \\
\text { The origin of this metric is } \\
\text { unknown; no citation was given. }\end{array}$ \\
\hline
\end{tabular}




\begin{tabular}{|l|l|l|l|}
\hline Names & Symbols & Definitions & References \\
\hline $\begin{array}{l}\text { Estimated } \\
\text { software } \\
\text { maturity } \\
\text { index }\end{array}$ & SMI & $\begin{array}{l}\text { If } F_{\text {a }} \text { and Fdel are unavailable, SMI may } \\
\text { be estimated as }\end{array}$ & $\begin{array}{l}\text { Unit: function/function or } \\
\text { module/module } \\
\text { Range: 0 to 1 }\end{array}$ \\
& $=\frac{M_{T}-F_{C}}{M_{T}}$ & $\begin{array}{l}\text { [IEEE-982.1-1988] } \\
\text { The origin of this metric is } \\
\text { unknown; no citation was given. }\end{array}$ \\
\hline
\end{tabular}

\section{Object-oriented design and implementation metrics}

\subsection{Eder, Kappel, and Schrefl scales of coupling and cohesion}

[Eder] adapted the earlier, general, ordinal scales of coupling and cohesion to object-oriented software, resulting in six ordinal-scaled metrics.

\begin{tabular}{|c|c|c|c|}
\hline Names & Symbols & Definitions & References \\
\hline $\begin{array}{l}\text { Interaction } \\
\text { coupling }\end{array}$ & & $\begin{array}{l}\text { (Based on module coupling, Sec. 7.5) } \\
\text { From most coupling (worst) to least coupling (best): } \\
\text { - Content: "One method directly accesses parts of the } \\
\text { internal structure, i.e., the implementation of another } \\
\text { method." } \\
\text { - Common: "Methods communicate via an unstructured, } \\
\text { global, shared data space." } \\
\text { - External: Methods communicate via a structured, } \\
\text { global, shared data space. } \\
\text { - Control: Methods "communicate exclusively via } \\
\text { parameter passing... but one method controls the internal } \\
\text { - logic of the other method." } \\
\text { - Stamp: "Whole data structures are passed as parameters } \\
\text { although only parts of the data structure would suffice." } \\
\text { Data: Methods "communicate only by parameters and } \\
\text { these parameters are relevant as a whole." } \\
\text { No direct coupling: "Two methods do not (directly) } \\
\text { depend on each other." }\end{array}$ & $\begin{array}{l}\text { Ordinal } \\
\text { [Eder] }\end{array}$ \\
\hline
\end{tabular}




\begin{tabular}{|c|c|c|c|}
\hline Names & Symbols & Definitions & References \\
\hline $\begin{array}{l}\text { Component } \\
\text { coupling }\end{array}$ & & $\begin{array}{l}\text { From most coupling (worst) to least coupling (best): } \\
\text { - Hidden: "C' shows up neither in the specification nor in } \\
\text { the implementation of } \mathrm{C} \text {, although an object of } \mathrm{C}^{\prime} \text { is } \\
\text { used in the implementation of a method of C." } \\
\text { - Scattered: "C' is used as domain in the definition of } \\
\text { some local variable or instance variable in the } \\
\text { implementation of C yet } \mathrm{C}^{\prime} \text { is not included in the } \\
\text { specification of C." } \\
\text { - Specified: "C' is included in the specification of C } \\
\text { whenever it is a component of C." } \\
\text { - Nil: "No direct component coupling." }\end{array}$ & $\begin{array}{l}\text { Ordinal } \\
\text { [Eder] }\end{array}$ \\
\hline $\begin{array}{l}\text { Inheritance } \\
\text { coupling }\end{array}$ & & $\begin{array}{l}\text { From most coupling (worst) to least coupling (best): } \\
\text { - Modification: "Inherited information is changed } \\
\text { arbitrarily or is even deleted." Includes signature and } \\
\text { implementation modification. } \\
\text { - } \quad \text { Refinement: "Inherited information is only changed due } \\
\text { to predefined rules." Includes signature and } \\
\text { implementation refinement. } \\
\text { - Extension: "The subclass only adds methods and } \\
\text { instance variables but neither modifies nor refines any of } \\
\text { the inherited ones." } \\
\text { - Nil: "No inheritance relationship." }\end{array}$ & $\begin{array}{l}\text { Ordinal } \\
\text { [Eder] }\end{array}$ \\
\hline
\end{tabular}




\begin{tabular}{|c|c|c|c|}
\hline Names & Symbols & Definitions & References \\
\hline $\begin{array}{l}\text { Method } \\
\text { cohesion }\end{array}$ & & $\begin{array}{l}\text { (Based on module cohesion, Sec. 7.5.) } \\
\text { From lowest (worst) to highest (best): } \\
\text { - Coincidental: "The elements of a method have nothing } \\
\text { in common besides being within the same method." } \\
\text { - Logical: "The elements with similar functionality, such } \\
\text { as input/output handling and error handling, are } \\
\text { collected in one method." } \\
\text { - Temporal: "The elements of a method have logical } \\
\text { cohesion and are performed at the same time." } \\
\text { - Procedural: "The elements of a method are connected } \\
\text { by some control flow." } \\
\text { - Communicational: "The elements of a method are } \\
\text { connected by some control flow and operate on the same } \\
\text { - Set of data." } \\
\text { - Sequential: "The elements of a method have } \\
\text { communicational cohesion and are connected by a } \\
\text { sequential control flow." } \\
\text { Functional: "The elements of a method have sequential } \\
\text { cohesion, and all elements contribute to a single task of } \\
\text { the problem domain." }\end{array}$ & $\begin{array}{l}\text { Ordinal } \\
\text { [Eder] }\end{array}$ \\
\hline $\begin{array}{l}\text { Class } \\
\text { cohesion }\end{array}$ & & $\begin{array}{l}\text { (Based on ADT cohesion, Sec. 7.6.) } \\
\text { From lowest (worst) to highest (best): } \\
\text { - Separable: The class represents multiple unrelated } \\
\text { abstractions that could easily be partitioned. } \\
\text { - Multifaceted: The class represents multiple unrelated } \\
\text { abstractions, but "at least one method references } \\
\text { instance variables or invokes methods of the different } \\
\text { semantic concepts, such that the cohesion of the } \\
\text { corresponding class cannot be rated separable." } \\
\text { - Non-delegated: "One method uses instance variables } \\
\text { which describe only a component of the respective } \\
\text { class." } \\
\text { - Concealed: "There exists some useful data abstraction } \\
\text { concealed in the data abstraction represented by the } \\
\text { class." } \\
\text { - Model: "The class represents a single, semantically } \\
\text { meaningful concept without containing methods which } \\
\text { should be delegated to other classes and without } \\
\text { containing concealed classes." }\end{array}$ & $\begin{array}{l}\text { Ordinal } \\
\text { [Eder] }\end{array}$ \\
\hline
\end{tabular}




\begin{tabular}{|l|l|l|l|}
\hline Names & Symbols & Definitions & References \\
\hline $\begin{array}{l}\text { Inheritance } \\
\text { cohesion }\end{array}$ & $\begin{array}{l}\text { "Inheritance cohesion in strong if this hierarchy is a } \\
\text { generalization hierarchy in the sense of conceptual } \\
\text { modeling, and it is weak if the inheritance hierarchy is } \\
\text { merely used for code sharing among otherwise unrelated } \\
\text { classes." Uses the same ordinal scale as class cohesion. }\end{array}$ & $\begin{array}{l}\text { Ordinal } \\
\text { [Eder] }\end{array}$ \\
\hline
\end{tabular}

\subsection{Martin's package metrics}

\begin{tabular}{|c|c|c|c|}
\hline Names & Symbols & Definitions & References \\
\hline $\begin{array}{l}\text { Relational } \\
\text { cohesion }\end{array}$ & $\mathrm{H}$ & $\begin{array}{l}=\frac{R+1}{N} \\
\text { where } \mathrm{R} \text { is "the number of class relationships } \\
\text { that are internal to the package (i.e., that do not } \\
\text { connect to classes outside the package)" and } \mathrm{N} \\
\text { is "the number of classes within the package." }\end{array}$ & $\begin{array}{l}\text { Unit: relationship/class } \\
\text { [Martin, p. 282] }\end{array}$ \\
\hline $\begin{array}{l}\text { Afferent } \\
\text { couplings }\end{array}$ & $\mathrm{C}_{\mathrm{a}}$ & $\begin{array}{l}\text { "The number of classes outside this package } \\
\text { that depend on classes within this package." }\end{array}$ & $\begin{array}{l}\text { Unit: class } \\
\text { [Martin, pp. 262, 282] }\end{array}$ \\
\hline $\begin{array}{l}\text { Efferent } \\
\text { couplings }\end{array}$ & $\mathrm{C}_{\mathrm{e}}$ & $\begin{array}{l}\text { "The number of classes inside this package } \\
\text { that depend on classes outside this package." }\end{array}$ & $\begin{array}{l}\text { Unit: class } \\
\text { [Martin, pp. 262, 282] }\end{array}$ \\
\hline Instability & $\mathrm{I}$ & $\begin{array}{l}I=\frac{C_{e}}{C_{a}+C_{e}} \\
\text { (I.e., the proportion of class dependencies that } \\
\text { are efferent.) }\end{array}$ & $\begin{array}{l}\text { Unit: class/class } \\
\text { Range: } 0 \text { (maximally } \\
\text { stable) to } 1 \text { (maximally } \\
\text { unstable) } \\
\text { [Martin, pp. 262, 282] }\end{array}$ \\
\hline Abstractness & $\mathrm{A}$ & $\begin{array}{l}A=\frac{N_{a}}{N_{c}} \\
\text { Where } \mathrm{N}_{\mathrm{c}} \text { is the number of classes in the } \\
\text { package and } \mathrm{N}_{\mathrm{a}} \text { is the number of abstract } \\
\text { classes in the package. } \\
\text { (I.e., the proportion of classes that are } \\
\text { abstract.) }\end{array}$ & $\begin{array}{l}\text { Unit: class/class } \\
\text { [Martin, pp. 265, 282] }\end{array}$ \\
\hline $\begin{array}{l}\text { Distance } \\
\text { [from the } \\
\text { main } \\
\text { sequence] }\end{array}$ & $\mathrm{D}$ & $D=\frac{|A+I-1|}{\sqrt{2}}$ & $\begin{array}{l}\text { Unit: class/class } \\
\text { Range: } 0 \text { (best) to } 1 / \\
\sqrt{2} \text { (worst) } \\
\text { [Martin, pp. 266, 282] }\end{array}$ \\
\hline $\begin{array}{l}\text { Normalized } \\
\text { distance }\end{array}$ & $\mathrm{D}^{\prime}$ & $D^{\prime}=|A+I-1|$ & $\begin{array}{l}\text { Unit: class/class } \\
\text { Range: } 0 \text { (best) to } 1 \\
\text { (worst) } \\
\text { [Martin, pp. 267, 282] }\end{array}$ \\
\hline
\end{tabular}

[Fenton] proposed a redefinition of relational cohesion (which he calls $R C(P)$ instead of $H$ ): 


\begin{tabular}{|l|l|l|l|}
\hline Names & Symbols \\
cohesion & RC' $(\mathrm{P})$ & $\begin{array}{l}\text { Definitions } \\
=\frac{R(P)+1}{N P(P)}\end{array}$ & $\begin{array}{l}\text { References } \\
\text { Unit: } \\
\text { relationship/relationship } \\
\text { [Fenton, pp. 420-421] }\end{array}$ \\
& & $\begin{array}{l}\text { classes and interfaces in a package" and NP(P) } \\
\text { is "the number of possible relations between } \\
\text { classes and interfaces in the package." On p. } \\
\text { 420, NP(P) is defined to be N(P) }(\mathrm{N}(\mathrm{P})-1) ; \\
\text { the absence of a factor of 2 in the denominator } \\
\text { suggests that the relations are considered one- } \\
\text { directional. }\end{array}$ & \\
& & \\
\hline
\end{tabular}

\subsection{Chidamber and Kemerer class metrics}

A suite of six object-oriented class metrics (metrics applied to a given class) is defined in [Chidamber]. These metrics are defined differently in earlier publications by the same authors.

The weighted methods per class (WMC) metric is excluded because its definition is incomplete (see Section 1.2). The authors wrote, "Complexity is deliberately not defined more specifically here in order to allow for the most general application of this metric" [Chidamber, footnote 13].

\begin{tabular}{|c|c|c|c|}
\hline Names & Symbols & Definitions & References \\
\hline $\begin{array}{l}\text { Depth of } \\
\text { inheritance } \\
\text { tree }\end{array}$ & DIT & $\begin{array}{l}\text { The length of the longest path from a given class to the } \\
\text { root of the inheritance tree (a.k.a. depth of node, Sec. } \\
\text { 4.3). }\end{array}$ & $\begin{array}{l}\text { Unit: arc } \\
\text { (graph entity) } \\
\text { [Chidamber] }\end{array}$ \\
\hline $\begin{array}{l}\text { Number of } \\
\text { children }\end{array}$ & NOC & $\begin{array}{l}\text { "Number of immediate subclasses subordinated to a class } \\
\text { in the class hierarchy." }\end{array}$ & $\begin{array}{l}\text { Unit: class } \\
\text { [Chidamber] }\end{array}$ \\
\hline $\begin{array}{l}\text { Coupling } \\
\text { between } \\
\text { object } \\
\text { classes }\end{array}$ & $\mathrm{CBO}$ & $\begin{array}{l}\text { "CBO for a class is a count of the number of other classes } \\
\text { to which it is coupled." "Two classes are coupled when } \\
\text { methods declared in one class use methods or instance } \\
\text { variables defined by the other class." }\end{array}$ & $\begin{array}{l}\text { Unit: class } \\
\text { [Chidamber] }\end{array}$ \\
\hline $\begin{array}{l}\text { Response } \\
\text { for a class }\end{array}$ & RFC & $\begin{array}{l}\text { The cardinality of the response set RS, "the set of } \\
\text { methods that can potentially be executed in response to a } \\
\text { message received by an object of that class," only up to } \\
\text { the first level of nesting of method calls. } \\
R S=\{M\} \bigcup\left\{R_{i}\right\} \\
\text { all } i \\
\text { where }\left\{\mathrm{R}_{\mathrm{i}}\right\}=\text { set of methods called by method } i \text { and }\{\mathrm{M}\} \\
=\text { set of all methods in the class. }\end{array}$ & $\begin{array}{l}\text { Unit: method } \\
\text { [Chidamber] }\end{array}$ \\
\hline
\end{tabular}




\begin{tabular}{|c|c|c|c|}
\hline Names & Symbols & Definitions & References \\
\hline $\begin{array}{l}\text { Lack of } \\
\text { cohesion } \\
\text { in methods }\end{array}$ & LCOM & 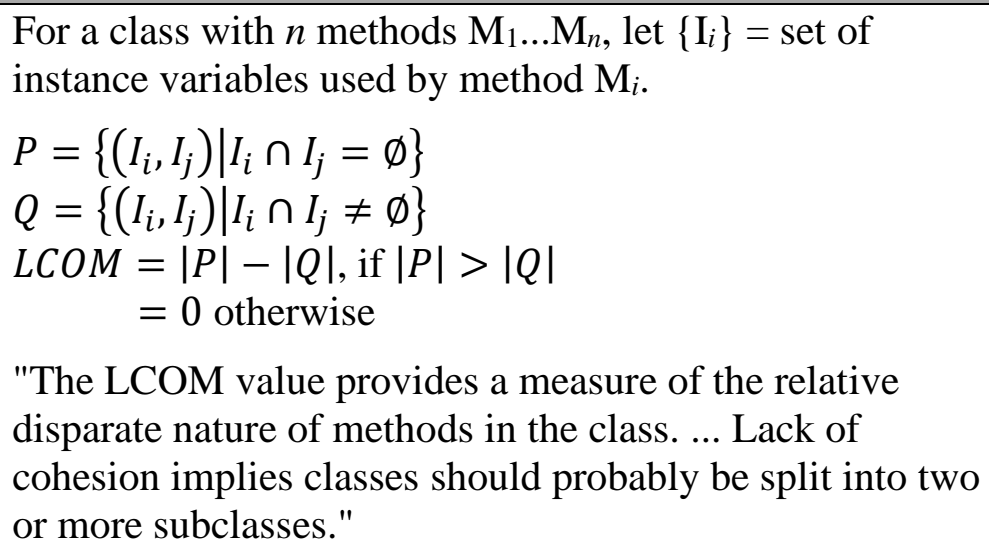 & $\begin{array}{l}\text { Unit: method } \\
\text { [Chidamber] }\end{array}$ \\
\hline
\end{tabular}

Revised definitions of LCOM proposed by other authors also are in use:

\begin{tabular}{|c|c|c|c|}
\hline Names & Symbols & Definitions & References \\
\hline $\begin{array}{l}\text { Hitz \& } \\
\text { Montazeri } \\
\text { LCOM }\end{array}$ & $\operatorname{LCOM}(X)$ & 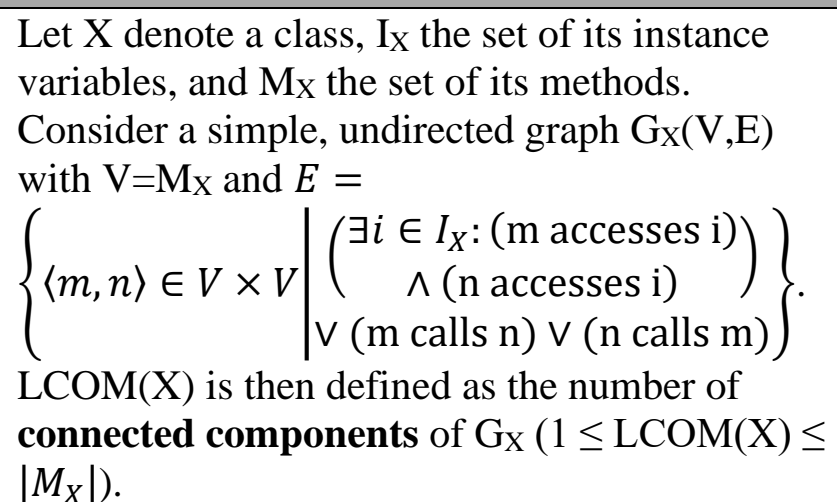 & $\begin{array}{l}\text { Unit: connected } \\
\text { component (graph } \\
\text { entity) } \\
\text { [Hitz] }\end{array}$ \\
\hline $\begin{array}{l}\text { First } \\
\text { version of } \\
\text { LCOM* }^{*}\end{array}$ & $\mathrm{LCOM}^{*}$ & $\begin{array}{l}\text { For a set of methods }\left\{\mathrm{M}_{\mathrm{i}}\right\}(\mathrm{i}=1 . . \mathrm{m}) \text { accessing a } \\
\text { set of attributes }\left\{\mathrm{A}_{\mathrm{j}}\right\}(\mathrm{j}=1 . . \mathrm{a}), \text { let } \alpha\left(\mathrm{M}_{\mathrm{i}}\right) \text { be the } \\
\text { number of attributes accessed by } \mathrm{M}_{\mathrm{i}} \text { and let } \\
\mu\left(\mathrm{A}_{\mathrm{j}}\right) \text { be the number of methods that access } \mathrm{A}_{\mathrm{j}} \text {. } \\
\text { Then LCOM* } \mathrm{LM}^{*} \\
\frac{\left(\frac{1}{a} \sum_{j=1}^{a} \mu\left(A_{j}\right)\right)\left(\frac{1}{m} \sum_{i=1}^{m} \alpha\left(M_{i}\right)\right)-a m}{1-a m}\end{array}$ & $\begin{array}{l}\text { Unit: (attribute } \\
\text { method) / (attribute } \\
\text { method) } \\
\text { Range: } 0 \text { (full } \\
\text { cohesion) to } 1 \text { (no } \\
\text { cohesion) } \\
\text { [Henderson-Sellers] }\end{array}$ \\
\hline $\begin{array}{l}\text { Second } \\
\text { version of } \\
\text { LCOM* }^{*}\end{array}$ & LCOM* & $\begin{array}{l}\text { Using the same definitions as ibid., LCOM }{ }^{*}= \\
\frac{\left(\frac{1}{a} \sum_{j=1}^{a} \mu\left(A_{j}\right)\right)-m}{1-m}\end{array}$ & $\begin{array}{l}\text { Unit: method/method } \\
\text { Range: } 0 \text { (full } \\
\text { cohesion) to } 1 \text { (no } \\
\text { cohesion) } \\
\text { [Henderson-Sellers] }\end{array}$ \\
\hline
\end{tabular}

\subsection{Bieman and Kang cohesion metrics}

[Bieman] defines general and local versions of two cohesion metrics, Tight Class Cohesion (TCC) and Loose Class Cohesion (LCC), which depend on an abstract model and several input quantities. The items in the abstract model are sets and multisets: 


\begin{tabular}{|c|c|c|c|}
\hline Names & Symbols & Definitions & References \\
\hline \multirow[t]{3}{*}{$\begin{array}{l}\text { Abstracted } \\
\text { method }\end{array}$} & $\mathrm{AM}(\mathrm{M})$ & $\begin{array}{l}\text { "A method is represented as a set of instance variables } \\
\text { directly or indirectly used by the method." } \\
\text { For the purposes of defining the metrics to follow, it suffices } \\
\text { that AM(M) is the model's proxy for a method, and that } \\
\text { constructors and destructors are not included in the model. }\end{array}$ & [Bieman] \\
\hline & $\mathrm{V}(\mathrm{C})$ & $\begin{array}{l}\text { "V(C) is a set of all visible methods in class } \mathrm{C} \text { and the } \\
\text { ancestor classes of C." }\end{array}$ & [Bieman] \\
\hline & $\mathrm{LV}(\mathrm{C})$ & "LV(C) are the visible methods defined within class C." & [Bieman] \\
\hline $\begin{array}{l}\text { Abstracted } \\
\text { class }\end{array}$ & $\mathrm{AC}(\mathrm{C})$ & $\begin{array}{l}\text { "A collection of AM's where each AM corresponds to a } \\
\text { visible method in the class." } \\
A C(C)=\llbracket A M(M) \mid M \in V(C) \rrbracket \\
\text { The double-bracket notation denotes a multi-set that may } \\
\text { contain duplicate elements, necessary because the AM } \\
\text { representations of different methods can be identical. }\end{array}$ & [Bieman] \\
\hline $\begin{array}{l}\text { Local } \\
\text { abstracted } \\
\text { class }\end{array}$ & $\mathrm{LAC}(\mathrm{C})$ & $\begin{array}{l}\text { "A collection of AM's where each AM corresponds to a } \\
\text { visible method defined only within the class:" } \\
L A C(C)=\llbracket A M(M) \mid M \in L V(C) \rrbracket\end{array}$ & [Bieman] \\
\hline
\end{tabular}

Quantities are derived from a graph in which nodes represent methods and edges represent connections as defined below:

\begin{tabular}{|c|c|c|c|}
\hline Names & Symbols & Definitions & References \\
\hline & $\mathrm{NP}(\mathrm{C})$ & $\begin{array}{l}\text { "The total number of pairs of abstracted methods in } \\
\text { AC(C). NP is the maximum possible number of direct or } \\
\text { indirect connections in a class. If there are } \mathrm{N} \text { methods in a } \\
\text { class } \mathrm{C}, " N P(C)=N \cdot(N-1) / 2 \text {. }\end{array}$ & $\begin{array}{l}\text { Unit: edge } \\
\text { (graph entity) } \\
\text { [Bieman] }\end{array}$ \\
\hline & $\operatorname{NDC}(\mathrm{C})$ & $\begin{array}{l}\text { "The number of direct connections in } \mathrm{AC}(\mathrm{C}) \text { " } \\
\text { "If there exists one or more common instance variables } \\
\text { between two method abstractions then the two } \\
\text { corresponding methods are directly connected." }\end{array}$ & $\begin{array}{l}\text { Unit: edge } \\
\text { (graph entity) } \\
\text { [Bieman] }\end{array}$ \\
\hline & NIC(C) & $\begin{array}{l}\text { "The number of indirect connections in AC(C)" } \\
\text { "Two methods that are connected through other directly } \\
\text { connected methods are indirectly connected. The indirect } \\
\text { connection relation is the transitive closure of direct } \\
\text { connection relation." }\end{array}$ & $\begin{array}{l}\text { Unit: edge } \\
\text { (graph entity) } \\
\text { [Bieman] }\end{array}$ \\
\hline $\begin{array}{l}\text { Tight class } \\
\text { cohesion }\end{array}$ & $\mathrm{TCC}(\mathrm{C})$ & $\begin{array}{l}\text { Described as "the relative number of directly connected } \\
\text { methods," but it is computed as a proportion of possible } \\
\text { connections, not of methods: } \\
T C C(C)=N D C(C) / N P(C)\end{array}$ & $\begin{array}{l}\text { Unit: } \\
\text { edge/edge } \\
\text { [Bieman] }\end{array}$ \\
\hline $\begin{array}{l}\text { Loose } \\
\text { class } \\
\text { cohesion }\end{array}$ & LCC(C) & $\begin{array}{l}\text { Described as "the relative number of directly or indirectly } \\
\text { connected methods," but it is computed as a proportion of } \\
\text { possible connections, not of methods: } \\
L C C(C)=(N D C(C)+N I C(C)) / N P(C)\end{array}$ & $\begin{array}{l}\text { Unit: } \\
\text { edge/edge } \\
\text { [Bieman] }\end{array}$ \\
\hline
\end{tabular}




\begin{tabular}{|l|l|l|l|}
\hline Names & Symbols & Definitions & References \\
\hline $\begin{array}{l}\text { Local } \\
\text { class } \\
\text { cohesion }\end{array}$ & $\begin{array}{l}\text { "Local class cohesion measures are defined by using the } \\
\text { local abstracted class (LAC) rather than the abstracted } \\
\text { class (AC)." Thus there would be "local" versions of both } \\
\text { LCC and TCC, substituting LAC(C) for AC(C) in the } \\
\text { input quantities. }\end{array}$ & $\begin{array}{l}\text { Unit: } \\
\text { edge/edge } \\
\text { [Bieman] }\end{array}$ \\
\hline
\end{tabular}

\subsection{Li and Henry coupling metrics}

\begin{tabular}{|l|l|l|l|}
\hline Names & Symbols & Definitions & References \\
\hline $\begin{array}{l}\text { Message- } \\
\text { passing } \\
\text { coupling }\end{array}$ & MPC & $\begin{array}{l}\text { "Number of send statements defined in a class." } \\
\text { [Briand99] interprets [Li] as excluding invocations of the } \\
\text { class' own methods and send statements in inherited } \\
\text { methods. }\end{array}$ & $\begin{array}{l}\text { Unit: call } \\
\text { [Li, Briand99] }\end{array}$ \\
\hline $\begin{array}{l}\text { Data } \\
\text { abstraction } \\
\text { coupling }\end{array}$ & DAC & $\begin{array}{l}\text { "Number of ADTs [abstract data types] defined in a } \\
\text { class." } \\
\text { [Briand99] provides two interpretations. }\end{array}$ & $\begin{array}{l}\text { Unit: ADT } \\
\text { [Li, Briand99] }\end{array}$ \\
\hline
\end{tabular}

\subsection{Briand, Devanbu, and Melo coupling metrics}

[Briand97] defines a suite of 18 object-oriented coupling metrics using a combinatoric approach. All the metrics "correspond to particular counts of interactions and are of the generic form:"

$$
\operatorname{Metric}\left(c_{i}\right)=\sum_{c_{j} \in \text { Relationship }\left(c_{i}\right)} \operatorname{Interactions}\left(c_{i}, c_{j}\right)
$$

The metrics are identified by 5 or 6 -letter acronyms constructed from three parts:

1. Relationship type

- IF: inverse friend, Friends ${ }^{-1}(\mathrm{c})$, "the set of classes that have $\mathrm{c}$ as a friend"

- F: friend, Friends(c), "the set of classes that are the friends of $c$ "

- D: descendant, Descendants(c), "the set of classes that are the descendants of $c^{\prime \prime}$

- A: ancestor, Ancestors(c), "the set of classes that are the ancestors of c. Ancestors(c) refers to the base classes of $\mathrm{c}$, and their base classes, and so on (closure)."

- O: others, Others(c), the set of other classes that have no inheritance or friendship relationship with $\mathrm{c}$

2. Interaction type (note, "when we discuss attributes and methods of a class $C$, we only mean newly defined or overriding methods and attributes of $C$, not ones inherited")

- CA: Class-Attribute interaction, the type of an attribute of one class refers to another class 
- $\quad$ CM: Class-Method interaction, the signature of a method of one class refers to another class

- MM: Method-Method interaction, a method of one class invokes a method of another class

3. Locus of impact

- IC: import coupling, class $\mathrm{C}$ is the using class

- EC: export coupling, class $c$ is the used class

Import coupling uses only IF, A, and $O$ relationships, and export coupling uses only $F, D$, and $O$ relationships, so the resulting number of metrics is $3 \times 3 \times 2=18$.

\subsection{Lee et al. coupling and cohesion metrics}

Model:

\begin{tabular}{|l|l|l|l|}
\hline Names & Symbols & Definitions & References \\
\hline Message tuple & $\mathrm{mt}$ & $\begin{array}{l}\text { mt } \text { (fn, na) } \\
\text { where fn is the function name and na is the } \\
\text { "argument number" (number of arguments). }\end{array}$ & [Lee, Def. 3.1] \\
\hline Function name & $\mathrm{fn}(\mathrm{mt})$ & Function name element of an mt & [Lee, Def. 3.1] \\
\hline Argument number & $\mathrm{na}(\mathrm{mt})$ & Argument number element of an mt & [Lee, Def. 3.1] \\
\hline Message-count tuple & $\mathrm{mct}$ & $\begin{array}{l}\text { mct }(\mathrm{mt}, \mathrm{nc}) \\
\text { where nc } \geq 0 \text { is the number of mts }\end{array}$ & [Lee, Def. 3.2] \\
\hline $\begin{array}{l}\text { Message-count tuple } \\
\text { set }\end{array}$ & $\mathrm{M}(\mathrm{f})$ & $\begin{array}{l}\text { Set of mcts for f, where f is a basic program } \\
\text { entity. }\end{array}$ & [Lee, Def. 3.2] \\
\hline $\begin{array}{l}\text { External flow set } \\
\text { set of f's mcts whose mts go to functions } \\
\text { defined in other classes. }\end{array}$ & $M_{E}^{C}(f)$ & $\begin{array}{l}\text { For member function (method) f of class C, the } \\
\text { [Lee, Def. 3.3] }\end{array}$ \\
\hline Internal flow set & $M_{I}^{C}(f)$ & $\begin{array}{l}\text { For member function (method) f of class C, the } \\
\text { set of f's mcts whose mts go to functions } \\
\text { defined in C. }\end{array}$ & [Lee, Def. 3.3] \\
\hline Inheritance flow set & $M_{I H}^{C}(f)$ & $\begin{array}{l}\text { Subset of } M_{E}^{C}(f) \text { where the target functions are } \\
\text { defined in a superclass of C. }\end{array}$ & [Lee, Def. 3.4] \\
\hline $\begin{array}{l}\text { Non-inheritance } \\
\text { flow set }\end{array}$ & $M_{N I H}^{C}(f)$ & $\begin{array}{l}\text { Subset of } M_{E}^{C}(f) \text { where the target functions are } \\
\text { defined outside the scope of C but not in a } \\
\text { superclass of C. }\end{array}$ & [Lee, Def. 3.4] \\
\hline
\end{tabular}

Quantities: 


\begin{tabular}{|c|c|c|c|}
\hline Names & Symbols & Definitions & References \\
\hline $\begin{array}{l}\text { I-based } \\
\text { coupling } \\
\text { contribution } \\
\text { (of } \mathrm{f} \text { to } \mathrm{C} \text { ) }\end{array}$ & $\operatorname{ICP}^{\mathrm{C}}(\mathrm{f})$ & $\begin{array}{l}I C P^{C}(f)=\sum_{i=1}^{n e(f)}\left[\left(1+n a\left(m t_{i}\right)\right) * n c\left(m c t_{i}\right)\right] \\
\text { where } m c t_{i} \in M_{E}^{C}(f), n e(f)=\left|M_{E}^{C}(f)\right| \text {, } \\
\text { and nc }\left(\mathrm{mct}_{\mathrm{i}}\right) \text { is the number of mcti's appearances } \\
\text { in f. }\end{array}$ & $\begin{array}{l}\text { Unit: argument } \\
\text { method } \\
\text { [Lee, Def. 3.5] }\end{array}$ \\
\hline $\begin{array}{l}\text { I-based } \\
\text { cohesion } \\
\text { contribution } \\
\text { (of } \mathrm{f} \text { to } \mathrm{C} \text { ) }\end{array}$ & $\mathrm{ICH}^{\mathrm{C}}(\mathrm{f})$ & $\begin{array}{l}I C H^{C}(f)=\sum_{j=1}^{n i(f)}\left[\left(1+n a\left(m t_{j}\right)\right) * n c\left(m c t_{j}\right)\right] \\
\text { where } m c t_{j} \in M_{I}^{C}(f) \text {, ni(f) }=\left|M_{I}^{C}(f)\right| \text {, } \\
\text { and nc }\left(\mathrm{mct}_{\mathrm{j}}\right) \text { is the number of mct's appearances } \\
\text { in } \mathrm{f} \text {. }\end{array}$ & $\begin{array}{l}\text { Unit: argument } \\
\text { method } \\
\text { [Lee, Def. 3.5] }\end{array}$ \\
\hline $\begin{array}{l}\text { I-based } \\
\text { inheritance } \\
\text { coupling } \\
\text { contribution }\end{array}$ & IH-ICPC(f) & Like $\operatorname{ICP}^{\mathrm{C}}(\mathrm{f})$, but substituting $M_{I H}^{C}(f)$ for $M_{E}^{C}(f)$. & $\begin{array}{l}\text { Unit: argument } \\
\text { method } \\
\text { [Lee, Def. 3.5] }\end{array}$ \\
\hline $\begin{array}{l}\text { I-based } \\
\text { non- } \\
\text { inheritance } \\
\text { coupling } \\
\text { contribution }\end{array}$ & NIH-ICPC $(f)$ & $\begin{array}{l}\operatorname{Like~ICPC}^{\mathrm{C}}(\mathrm{f}) \text {, but substituting } M_{N I H}^{C}(f) \text { for } \\
M_{E}^{C}(f) \text {. }\end{array}$ & $\begin{array}{l}\text { Unit: argument } \\
\text { method } \\
\text { [Lee, Def. 3.5] }\end{array}$ \\
\hline $\begin{array}{l}\text { I-based } \\
\text { coupling } \\
\text { (of class C) }\end{array}$ & ICP(C) & $I C P(C)=\sum_{k=1}^{n} I C P^{C}\left(f_{k}\right)$ & $\begin{array}{l}\text { Unit: argument } \\
\text { method } \\
\text { [Lee, Def. 3.6] }\end{array}$ \\
\hline $\begin{array}{l}\text { I-based } \\
\text { inheritance } \\
\text { coupling } \\
\text { (of class C) }\end{array}$ & IH-ICP(C) & $\begin{array}{l}\text { Like ICP(C), but substituting IH-ICP }^{\mathrm{C}}\left(f_{k}\right) \text { for } \\
\operatorname{ICP}^{\mathrm{C}}\left(\mathrm{f}_{k}\right) \text {. }\end{array}$ & $\begin{array}{l}\text { Unit: argument } \\
\text { method } \\
\text { [Lee, Def. 3.6] }\end{array}$ \\
\hline $\begin{array}{l}\text { I-based } \\
\text { non- } \\
\text { inheritance } \\
\text { coupling } \\
\text { (of class C) }\end{array}$ & NIH-ICP(C) & $\begin{array}{l}\text { Like ICP(C), but substituting NIH-ICP }{ }^{\mathrm{C}}\left(\mathrm{f}_{\mathrm{k}}\right) \text { for } \\
\operatorname{ICP}^{\mathrm{C}}\left(\mathrm{f}_{\mathrm{k}}\right) \text {. }\end{array}$ & $\begin{array}{l}\text { Unit: argument } \\
\text { method } \\
\text { [Lee, Def. 3.6] }\end{array}$ \\
\hline $\begin{array}{l}\text { I-based } \\
\text { cohesion } \\
\text { (of class C) }\end{array}$ & $\mathrm{ICH}(\mathrm{C})$ & $I C H(C)=\sum_{k=1}^{n} I C H^{C}\left(f_{k}\right)$ & $\begin{array}{l}\text { Unit: argument } \\
\text { method } \\
\text { [Lee, Def. 3.6] }\end{array}$ \\
\hline
\end{tabular}

[Lee, Def. 3.7] proceeds to define analogous $\mathrm{ICP}(\mathrm{H})$ and $\mathrm{ICH}(\mathrm{H})$ for a class hierarchy $\mathrm{H}$ using definitions that are similar to the above except that they are scoped to the class hierarchy instead of a single class. 


\subsection{MOOD2 metrics}

[Abreu] contains formal definitions of the following, expressed in Object Constraint Language (OCL). MOOD2 is a superset of the older MOOD (Metrics for Object-Oriented Design) suite of metrics, with the exception that the coupling factor was redefined. The old definition is included below for completeness.

\begin{tabular}{|c|c|c|c|}
\hline Names & Symbols & Definitions & References \\
\hline $\begin{array}{l}\text { Attribute } \\
\text { inheritance factor }\end{array}$ & AIF & $\begin{array}{l}\text { "Quotient between the number of } \\
\text { inherited attributes in all classes of the } \\
\text { specification and the number of available } \\
\text { attributes (locally defined plus inherited) } \\
\text { for all classes of the current } \\
\text { specification." }\end{array}$ & $\begin{array}{l}\text { Unit: attribute/attribute } \\
\text { Range: } 0 \text { to } 1 \\
\text { [Abreu] }\end{array}$ \\
\hline $\begin{array}{l}\text { Operations } \\
\text { inheritance } \\
\text { factor, } \\
\text { Methods } \\
\text { inheritance factor }\end{array}$ & $\begin{array}{l}\text { OIF, } \\
\text { MIF }\end{array}$ & $\begin{array}{l}\text { "Quotient between the number of } \\
\text { inherited operations in all classes of the } \\
\text { specification and the number of available } \\
\text { operations (locally defined plus } \\
\text { inherited) for all classes of the current } \\
\text { specification." }\end{array}$ & $\begin{array}{l}\text { Unit: method/method } \\
\text { Range: } 0 \text { to } 1 \\
\text { [Abreu] }\end{array}$ \\
\hline $\begin{array}{l}\text { Internal } \\
\text { inheritance factor }\end{array}$ & IIF & $\begin{array}{l}\text { "Quotient between the number of } \\
\text { inheritance links where both the base and } \\
\text { derived classes belong to the current } \\
\text { specification and the total number of } \\
\text { inheritance links originating in the } \\
\text { current specification." }\end{array}$ & $\begin{array}{l}\text { Unit: } \\
\text { relationship/relationship } \\
\text { Range: } 0 \text { to } 1 \\
\text { [Abreu] }\end{array}$ \\
\hline $\begin{array}{l}\text { Attribute hiding } \\
\text { factor }\end{array}$ & AHF & $\begin{array}{l}\text { "Quotient between the sum of the } \\
\text { invisibilities of all attributes defined in } \\
\text { all classes in the current specification } \\
\text { and the total number of attributes defined } \\
\text { in the specification." "The invisibility of } \\
\text { an attribute is the percentage } \\
\text { [proportion] of the total classes in the } \\
\text { specification from which this attribute is } \\
\text { not visible" }\end{array}$ & $\begin{array}{l}\text { Unit: attribute/attribute } \\
\text { Range: } 0 \text { to } 1 \\
\text { [Abreu] }\end{array}$ \\
\hline $\begin{array}{l}\text { Operations hiding } \\
\text { factor, } \\
\text { Methods hiding } \\
\text { factor }\end{array}$ & $\begin{array}{l}\text { OHF, } \\
\text { MHF }\end{array}$ & $\begin{array}{l}\text { "Quotient between the sum of the } \\
\text { invisibilities of all operations defined in } \\
\text { all classes in the current specification } \\
\text { and the total number of operations } \\
\text { defined in the specification." "The } \\
\text { invisibility of an operation is the } \\
\text { percentage [proportion] of the total } \\
\text { classes in the specification from which } \\
\text { this operation is not visible" }\end{array}$ & $\begin{array}{l}\text { Unit: method/method } \\
\text { Range: } 0 \text { to } 1 \\
\text { [Abreu] }\end{array}$ \\
\hline
\end{tabular}




\begin{tabular}{|c|c|c|c|}
\hline Names & Symbols & Definitions & References \\
\hline $\begin{array}{l}\text { Attributes hiding } \\
\text { effectiveness } \\
\text { factor }\end{array}$ & AHEF & $\begin{array}{l}\text { "Quotient between the cumulative } \\
\text { number of the specification classes that } \\
d o \text { access the specification attributes and } \\
\text { the cumulative number of the } \\
\text { specification classes that can access the } \\
\text { specification attributes." }\end{array}$ & $\begin{array}{l}\text { Unit: class/class } \\
\text { Range: } 0 \text { to } 1 \\
\text { [Abreu] }\end{array}$ \\
\hline $\begin{array}{l}\text { Operations hiding } \\
\text { effectiveness } \\
\text { factor }\end{array}$ & OHEF & $\begin{array}{l}\text { "Quotient between the cumulative } \\
\text { number of the specification classes that } \\
d o \text { access the specification operations } \\
\text { and the cumulative number of the } \\
\text { specification classes that can access the } \\
\text { specification operations." }\end{array}$ & $\begin{array}{l}\text { Unit: class/class } \\
\text { Range: } 0 \text { to } 1 \\
\text { [Abreu] }\end{array}$ \\
\hline $\begin{array}{l}\text { Behavioral } \\
\text { polymorphism } \\
\text { factor, } \\
\text { Polymorphism } \\
\text { factor }\end{array}$ & $\begin{array}{l}\text { BPF, } \\
\text { POF }\end{array}$ & $\begin{array}{l}\text { "Quotient between the actual number of } \\
\text { possible different polymorphic situations } \\
\text { and the maximum number of possible } \\
\text { distinct polymorphic situations (due to } \\
\text { inheritance)" }\end{array}$ & $\begin{array}{l}\text { Unit: method/method } \\
\text { Range: } 0 \text { to } 1 \\
\text { [Abreu] }\end{array}$ \\
\hline $\begin{array}{l}\text { Parametric } \\
\text { polymorphism } \\
\text { factor }\end{array}$ & PPF & $\begin{array}{l}\text { "Percentage [proportion] of the } \\
\text { specification classes that are } \\
\text { parameterized" }\end{array}$ & $\begin{array}{l}\text { Unit: class/class } \\
\text { Range: } 0 \text { to } 1 \\
\text { [Abreu] }\end{array}$ \\
\hline $\begin{array}{l}\text { Class coupling } \\
\text { factor }\end{array}$ & CCF & $\begin{array}{l}\text { Square root of the "Quotient between the } \\
\text { actual number of coupled class-pairs } \\
\text { within the specification and the } \\
\text { maximum possible number of class-pair } \\
\text { couplings in the specification. This } \\
\text { coupling is the one not imputable to } \\
\text { inheritance." }\end{array}$ & $\begin{array}{l}\text { Transformed ratio } \\
\text { Range: } 0 \text { to } 1 \\
\text { [Abreu] }\end{array}$ \\
\hline Coupling factor & COF & $\begin{array}{l}=\mathrm{CCF}^{2} \\
\text { (As defined in the original MOOD set) }\end{array}$ & $\begin{array}{l}\text { Unit: } \\
\text { relationship/relationship } \\
\text { Range: } 0 \text { to } 1 \\
\text { [Abreu] }\end{array}$ \\
\hline $\begin{array}{l}\text { Internal coupling } \\
\text { factor }\end{array}$ & ICF & $\begin{array}{l}\text { "Quotient between the number of } \\
\text { coupling links where both the client and } \\
\text { supplier classes belong to the current } \\
\text { specification and the total number of } \\
\text { coupling links originating in the current } \\
\text { specification." }\end{array}$ & $\begin{array}{l}\text { Unit: } \\
\text { relationship/relationship } \\
\text { Range: } 0 \text { to } 1 \\
\text { [Abreu] }\end{array}$ \\
\hline $\begin{array}{l}\text { External } \\
\text { inheritance factor }\end{array}$ & EIF(S) & $\begin{array}{l}\text { "Quotient between the number of } \\
\text { external inheritance links to specification } \\
\text { "s" and the total number of inheritance } \\
\text { links originating in the current } \\
\text { specification. }\end{array}$ & $\begin{array}{l}\text { Unit: } \\
\text { relationship/relationship } \\
\text { Range: } 0 \text { to } 1 \\
\text { [Abreu] }\end{array}$ \\
\hline
\end{tabular}




\begin{tabular}{|l|l|l|l|}
\hline Names & Symbols & Definitions & References \\
\hline $\begin{array}{l}\text { External coupling } \\
\text { factor }\end{array}$ & ECF(S) & $\begin{array}{l}\text { "Quotient between the number of } \\
\text { external coupling links to specification } \\
\text { "s" and the total number of coupling } \\
\text { links originating in the current } \\
\text { specification." }\end{array}$ & $\begin{array}{l}\text { Unit: } \\
\text { relationship/relationship } \\
\text { Range: 0 to 1 } \\
\text { [Abreu] }\end{array}$ \\
\hline $\begin{array}{l}\text { Potential reuse } \\
\text { factor }\end{array}$ & PRF(S) & $\begin{array}{l}\text { "Percentage [proportion] of the available } \\
\text { operations in the current specification } \\
\text { that were imported from the "s" } \\
\text { specification." }\end{array}$ & $\begin{array}{l}\text { Unit: method/method } \\
\text { Range: 0 to 1 } \\
\text { [Abreu] }\end{array}$ \\
\hline $\begin{array}{l}\text { Actual reuse } \\
\text { factor }\end{array}$ & ARF(S) & $\begin{array}{l}\text { "Percentage [proportion] of the available } \\
\text { operations in the current specification } \\
\text { that corresponds to effectively used } \\
\text { operations imported from the "s" } \\
\text { specification" }\end{array}$ & $\begin{array}{l}\text { Unit: method/method } \\
\text { Range: 0 to 1 } \\
\text { [Abreu] }\end{array}$ \\
\hline $\begin{array}{l}\text { Reuse efficiency } \\
\text { factor }\end{array}$ & REF(S) & $\begin{array}{l}\text { "Percentage [proportion] of the imported } \\
\text { operations (from the "s” specification) } \\
\text { that are effectively used" }\end{array}$ & $\begin{array}{l}\text { Unit: method/method } \\
\text { Range: 0 to 1 } \\
\text { [Abreu] }\end{array}$ \\
\hline
\end{tabular}

\subsection{Lorenz and Kidd metrics}

Many of the metrics defined in [Lorenz] are simple counts or obvious derivatives (e.g., average number of support classes per key class $=\mathrm{NSC} / \mathrm{NKC}$ ), but their rich set of symbols is used in other works. Those without symbols or with already-defined symbols (LOC) have been omitted.

Project metrics, application size:

\begin{tabular}{|l|l|l|l|}
\hline Names & Symbols & Definitions & References \\
\hline $\begin{array}{l}\text { Number of scenario } \\
\text { scripts }\end{array}$ & NSS & Number of use cases. & $\begin{array}{l}\text { Unit: use case } \\
\text { [Lorenz] }\end{array}$ \\
\hline $\begin{array}{l}\text { Number of key } \\
\text { classes }\end{array}$ & NKC & $\begin{array}{l}\text { Number of classes "that are deemed to be of } \\
\text { central importance to the business." }\end{array}$ & $\begin{array}{l}\text { Unit: class } \\
\text { [Lorenz] }\end{array}$ \\
\hline $\begin{array}{l}\text { Number of support } \\
\text { classes }\end{array}$ & NSC & $\begin{array}{l}\text { Number of classes that are "not central to the } \\
\text { business domain." }\end{array}$ & $\begin{array}{l}\text { Unit: class } \\
\text { [Lorenz] }\end{array}$ \\
\hline $\begin{array}{l}\text { Number of } \\
\text { subsystems }\end{array}$ & NOS & Number of packages. & $\begin{array}{l}\text { Unit: package } \\
\text { [Lorenz] }\end{array}$ \\
\hline
\end{tabular}

Design metrics, method size:

\begin{tabular}{|l|l|l|l|}
\hline Names & Symbols & Definitions & References \\
\hline $\begin{array}{l}\text { Number of message } \\
\text { sends }\end{array}$ & NOM & "Number of messages sent in the method" & $\begin{array}{l}\text { Unit: call } \\
\text { [Lorenz] }\end{array}$ \\
\hline
\end{tabular}

Design metrics, method internals: 


\begin{tabular}{|c|c|c|c|}
\hline Names & Symbols & Definitions & References \\
\hline Method complexity & MCX & $\begin{array}{l}\text { Sum of the following, weighted as shown: } \\
\text { Application Programming Interface (API) } \\
\text { calls: } 5.0 \\
\text { Assignments: } 0.5 \\
\text { Binary expressions (Smalltalk) or arithmetic } \\
\text { operators (C++): } 2.0 \\
\text { Keyword messages (Smalltalk) or messages } \\
\text { with parameters (C++): } 3.0 \\
\text { Nested expressions: } 0.5 \\
\text { Parameters: } 0.3 \\
\text { Primitive calls: } 7.0 \\
\text { Temporary variables: } 0.5 \\
\text { Unary expressions (Smalltalk) or messages } \\
\text { without parameters (C++): } 1.0\end{array}$ & $\begin{array}{l}\text { Ordinal } \\
\text { [Lorenz] }\end{array}$ \\
\hline $\begin{array}{l}\text { Strings of message } \\
\text { sends }\end{array}$ & SMS & $\begin{array}{l}\text { Number of expressions where } \\
\text { messages/calls are strung together like } \\
\text { self.account().balance().print(). }\end{array}$ & $\begin{array}{l}\text { Unit: expression } \\
\text { [Lorenz] }\end{array}$ \\
\hline
\end{tabular}

Design metrics, class size:

\begin{tabular}{|l|l|l|l|}
\hline Names & Symbols & Definitions & References \\
\hline $\begin{array}{l}\text { Number of public instance } \\
\text { methods }\end{array}$ & PIM & $\begin{array}{l}\text { Number of instance methods with public } \\
\text { visibility. }\end{array}$ & $\begin{array}{l}\text { Unit: method } \\
\text { [Lorenz] }\end{array}$ \\
\hline $\begin{array}{l}\text { Number of instance } \\
\text { methods }\end{array}$ & NIM & $\begin{array}{l}\text { Number of instance methods (public, } \\
\text { protected, and private) }\end{array}$ & $\begin{array}{l}\text { Unit: method } \\
\text { [Lorenz] }\end{array}$ \\
\hline $\begin{array}{l}\text { Number of instance } \\
\text { variables }\end{array}$ & NIV & $\begin{array}{l}\text { Number of instance variables (public, } \\
\text { protected, and private). }\end{array}$ & $\begin{array}{l}\text { Unit: variable } \\
\text { [Lorenz] }\end{array}$ \\
\hline Number of class methods & NCM & Number of class methods. & $\begin{array}{l}\text { Unit: method } \\
\text { [Lorenz] }\end{array}$ \\
\hline Number of class variables & NCV & Number of class variables. & $\begin{array}{l}\text { Unit: variable } \\
\text { [Lorenz] }\end{array}$ \\
\hline
\end{tabular}

Design metrics, class inheritance:

\begin{tabular}{|l|l|l|l|}
\hline Names & Symbols & Definitions & References \\
\hline $\begin{array}{l}\text { Hierarchy nesting } \\
\text { level }\end{array}$ & HNL & = DIT (Sec. 8.3) & $\begin{array}{l}\text { Unit: arc } \\
\text { [Lorenz] }\end{array}$ \\
\hline Multiple inheritance & MUI & Use of multiple inheritance (yes or no). & $\begin{array}{l}\text { Dichotomic } \\
\text { [Lorenz] }\end{array}$ \\
\hline
\end{tabular}

Design metrics, method inheritance:

\begin{tabular}{|l|l|l|l|}
\hline Names & Symbols & Definitions & References \\
\hline $\begin{array}{l}\text { Number of methods } \\
\text { overridden }\end{array}$ & NMO & Number of methods overridden by a subclass. & $\begin{array}{l}\text { Unit: method } \\
\text { [Lorenz }]\end{array}$ \\
\hline
\end{tabular}




\begin{tabular}{|l|l|l|l|}
\hline Names & Symbols & Definitions & References \\
\hline $\begin{array}{l}\text { Number of methods } \\
\text { inherited }\end{array}$ & NMI & Number of methods inherited by a subclass. & $\begin{array}{l}\text { Unit: method } \\
\text { [Lorenz }\end{array}$ \\
\hline $\begin{array}{l}\text { Number of methods } \\
\text { added }\end{array}$ & NMA & Number of methods added by a subclass. & $\begin{array}{l}\text { Unit: method } \\
\text { [Lorenz }\end{array}$ \\
\hline Specialization index & SIX & $\begin{array}{l}\text { For each class, } \\
\text { = HNL } \cdot \text { NMO / methods }\end{array}$ & $\begin{array}{l}\text { Ordinal } \\
\text { [Lorenz }]\end{array}$ \\
\hline
\end{tabular}

Design metrics, class internals:

\begin{tabular}{|c|c|c|c|}
\hline Names & Symbols & Definitions & References \\
\hline Global usage & GUS & $\begin{array}{l}\text { Number of references to global } \\
\text { variables. }\end{array}$ & $\begin{array}{l}\text { Unit: operand } \\
\text { [Lorenz] }\end{array}$ \\
\hline $\begin{array}{l}\text { Instance variable } \\
\text { usage }\end{array}$ & IVU & $\begin{array}{l}\text { Number of references to instance } \\
\text { variables. }\end{array}$ & $\begin{array}{l}\text { Unit: operand } \\
\text { [Lorenz] }\end{array}$ \\
\hline $\begin{array}{l}\text { Parameters per } \\
\text { method }\end{array}$ & PPM & = parameters / methods & $\begin{array}{l}\text { Unit: parameter/method } \\
\text { [Lorenz] }\end{array}$ \\
\hline Friend functions & FFU & Use of friend functions (yes or no). & $\begin{array}{l}\text { Dichotomic } \\
\text { [Lorenz] }\end{array}$ \\
\hline $\begin{array}{l}\text { Function-oriented } \\
\text { code }\end{array}$ & FOC & $\begin{array}{l}\text { Proportion of functions that are } \\
\text { outside of classes. } \\
\text { As with MUI and FFU, [Lorenz] sets } \\
\text { a threshold of zero, suggesting a } \\
\text { dichotomic metric, but the section } \\
\text { heading is "percentage of function- } \\
\text { oriented code." }\end{array}$ & $\begin{array}{l}\text { Unit: function/function } \\
\text { [Lorenz] }\end{array}$ \\
\hline $\begin{array}{l}\text { Comment lines per } \\
\text { method }\end{array}$ & CLM & = CMT / methods & $\begin{array}{l}\text { Unit: CMT/method } \\
\text { [Lorenz] }\end{array}$ \\
\hline $\begin{array}{l}\text { Percentages of } \\
\text { commented } \\
\text { methods }\end{array}$ & PCM & $\begin{array}{l}\text { Proportion of methods that have any } \\
\text { comments in them. }\end{array}$ & $\begin{array}{l}\text { Unit: method/method } \\
\text { [Lorenz] }\end{array}$ \\
\hline $\begin{array}{l}\text { Problem reports per } \\
\text { class }\end{array}$ & PRC & $=$ bug reports $/$ classes & $\begin{array}{l}\text { Unit: bug report/class } \\
\text { [Lorenz] }\end{array}$ \\
\hline
\end{tabular}

The following metrics with symbols either were not clearly defined or are out of scope:

\begin{tabular}{|l|l|l|}
\hline Names & Symbols & Category \\
\hline Class cohesion & CCO & Class internals \\
\hline Class coupling & CCP & Class externals \\
\hline Class reuse & CRE & Class externals \\
\hline Number of classes thrown away & NCT & Class externals \\
\hline Number of collaborations & NCO & Class externals \\
\hline Intersubsystem relationships & ISR & Subsystem coupling \\
\hline Interclass relationships & ICR & Subsystem coupling \\
\hline Person-days per class & PDC & Staffing size \\
\hline
\end{tabular}




\begin{tabular}{|l|l|l|}
\hline Names & Symbols & Category \\
\hline Classes per developer & CPD & Staffing size \\
\hline Number of major iterations & NMI & Scheduling \\
\hline Number of contracts completed & NCC & Scheduling \\
\hline
\end{tabular}

\section{Testability (test coverage) metrics}

The following chapter lists test coverage metrics. Given any test coverage metric, a corresponding testability metric that is applicable to the software product in isolation can be produced based on the amount of testing that the metric would require to indicate full coverage. For example, given the path coverage metric, one can inversely relate testability to the number of linearly independent paths.

\subsection{Rapps, Frankl, and Weyuker data flow coverage metrics}

Definitions quoted below from [Frankl] are more formalized versions of ones that appeared earlier in [Rapps].

Model:

\begin{tabular}{|c|c|c|}
\hline Symbols & Definitions & References \\
\hline $\mathrm{V}$ & The set of variables. & [Frankl] \\
\hline $\mathrm{N}$ & The set of nodes, which correspond to the blocks of the subprogram. & [Frankl] \\
\hline $\mathrm{E}$ & The set of edges, which indicate possible flow of control between blocks. & [Frankl] \\
\hline $\operatorname{def}(\mathrm{i})$ & $\{\mathrm{x} \in \mathrm{V} \mid \mathrm{x}$ has a global definition in block $\mathrm{i}\}$ & [Frankl] \\
\hline c-use(i) & $\{\mathrm{x} \in \mathrm{V} \mid \mathrm{x}$ has a global $\mathrm{c}$-use in block $\mathrm{i}\}$ & [Frankl] \\
\hline p-use $(i, j)$ & $\{\mathrm{x} \in \mathrm{V} \mid \mathrm{x}$ has a $\mathbf{p}$-use in edge $(\mathrm{i}, \mathrm{j})\}$ & [Frankl] \\
\hline $\operatorname{dcu}(\mathrm{x}, \mathrm{i})$ & $\{\mathrm{j} \in \mathrm{N} \mid \mathrm{x} \in \mathrm{c}$-use $(\mathrm{j})$ and there is a def-clear path wrt $\mathrm{x}$ from $\mathrm{i}$ to $\mathrm{j}\}$ & [Frankl] \\
\hline $\operatorname{dpu}(x, i)$ & $\begin{array}{l}\{(\mathrm{j}, \mathrm{k}) \in \mathrm{E} \mid \mathrm{x} \in \mathrm{p} \text {-use }(\mathrm{j}, \mathrm{k}) \text { and there is a def-clear path wrt } \mathrm{x} \text { from } \mathrm{i} \text { to } \\
(\mathrm{j}, \mathrm{k})\}\end{array}$ & [Frankl] \\
\hline
\end{tabular}

Metrics:

\begin{tabular}{|l|l|l|l|}
\hline Names & Symbols & Definitions & References \\
\hline All-paths & & Coverage of every path in a def/use graph. & $\begin{array}{l}\text { Dichotomic } \\
\text { [Frankl] }\end{array}$ \\
\hline
\end{tabular}




\begin{tabular}{|c|c|c|c|}
\hline Names & Symbols & Definitions & References \\
\hline All-du-paths & & $\begin{array}{l}\text { All du-paths from } \mathrm{i} \text { to } \mathrm{j} \text { with respect to } \mathrm{x} \text { for each } \\
\mathrm{j} \in \mathrm{dcu}(\mathrm{x}, \mathrm{i}) \text { and all du-paths from } \mathrm{i} \text { to }(\mathrm{j}, \mathrm{k}) \text { with respect to } \\
\mathrm{x} \text { for each }(\mathrm{j}, \mathrm{k}) \in \mathrm{dpu}(\mathrm{x}, \mathrm{i}) \text {. } \\
\text { A path }\left(\mathrm{n}_{1}, \ldots, \mathrm{n}_{\mathrm{j}}, \mathrm{n}_{\mathrm{k}}\right) \text { is a du-path with respect to a variable } \\
\mathrm{x} \text { if } \mathrm{n}_{1} \text { has a global definition of } \mathrm{x} \text { and either } \\
\text { 1) } \mathrm{n}_{\mathrm{k}} \text { has a global c-use of } \mathrm{x} \text { and }\left(\mathrm{n}_{1}, \ldots, \mathrm{n}_{\mathrm{j}}, \mathrm{n}_{\mathrm{k}}\right) \text { is a def- } \\
\text { clear simple path with respect to } \mathrm{x}, \text { or } \\
\text { 2) }\left(\mathrm{n}_{\mathrm{j}}, \mathrm{n}_{\mathrm{k}}\right) \text { has a p-use of } \mathrm{x} \text { and }\left(\mathrm{n}_{1}, \ldots, \mathrm{n}_{\mathrm{j}}, \mathrm{n}_{\mathrm{k}}\right) \text { is a def-clear } \\
\text { loop-free path with respect to } \mathrm{x} \text {. } \\
\text { A simple path is one in which all nodes, except possibly } \\
\text { the first and last, are distinct. A loop-free path is one in } \\
\text { which all nodes are distinct. }\end{array}$ & $\begin{array}{l}\text { Dichotomic } \\
\text { [Frankl] }\end{array}$ \\
\hline All-uses & & $\begin{array}{l}\text { For each node } i \text { and each } x \in \operatorname{def}(i) \text {, coverage of all }(i, j, x) \\
\text { s.t. } j \in \operatorname{dcu}(x, i) \text { and all }(i,(j, k), x) \text { s.t. }(j, k) \in \operatorname{dpu}(x, i) \text {. }\end{array}$ & $\begin{array}{l}\text { Dichotomic } \\
\text { [Frankl] }\end{array}$ \\
\hline $\begin{array}{l}\text { All-c-uses / } \\
\text { some-p-uses }\end{array}$ & & $\begin{array}{l}\text { For each node } \mathrm{i} \text { and each } \mathrm{x} \in \operatorname{def}(\mathrm{i}) \text {, coverage of all }(\mathrm{i}, \mathrm{j}, \mathrm{x}) \\
\text { s.t. } \mathrm{j} \in \mathrm{dcu}(\mathrm{x}, \mathrm{i}) \text {. In addition, if } \mathrm{dcu}(\mathrm{x}, \mathrm{i}) \text { is empty, then } \\
\text { some }(\mathrm{i},(\mathrm{j}, \mathrm{k}), \mathrm{x}) \text { s.t. }(\mathrm{j}, \mathrm{k}) \in \mathrm{dpu}(\mathrm{x}, \mathrm{i}) \text {. }\end{array}$ & $\begin{array}{l}\text { Dichotomic } \\
\text { [Frankl] }\end{array}$ \\
\hline $\begin{array}{l}\text { All-p-uses / } \\
\text { some-c-uses }\end{array}$ & & $\begin{array}{l}\text { For each node } \mathrm{i} \text { and each } \mathrm{x} \in \operatorname{def}(\mathrm{i}) \text {, coverage of all } \\
(\mathrm{i},(\mathrm{j}, \mathrm{k}), \mathrm{x}) \text { s.t. }(\mathrm{j}, \mathrm{k}) \in \operatorname{dpu}(\mathrm{x}, \mathrm{i}) \text {. In addition, if } \operatorname{dpu}(\mathrm{x}, \mathrm{i}) \text { is } \\
\text { empty, then some }(\mathrm{i}, \mathrm{j}, \mathrm{x}) \text { s.t. } \mathrm{j} \in \operatorname{dcu}(\mathrm{x}, \mathrm{i}) \text {. }\end{array}$ & $\begin{array}{l}\text { Dichotomic } \\
\text { [Frankl] }\end{array}$ \\
\hline All-defs & & $\begin{array}{l}\text { For each node } i \text { and each } x \in \operatorname{def}(i) \text {, coverage of some } \\
(\mathrm{i}, \mathrm{j}, \mathrm{x}) \text { s.t. } \mathrm{j} \in \mathrm{dcu}(\mathrm{x}, \mathrm{i}) \text { or some }(\mathrm{i},(\mathrm{j}, \mathrm{k}), \mathrm{x}) \text { s.t. }(\mathrm{j}, \mathrm{k}) \in \mathrm{dpu}(\mathrm{x}, \mathrm{i}) \text {. }\end{array}$ & $\begin{array}{l}\text { Dichotomic } \\
\text { [Frankl] }\end{array}$ \\
\hline All-c-uses & & $\begin{array}{l}\text { For each node } \mathrm{i} \text { and each } \mathrm{x} \in \operatorname{def}(\mathrm{i}) \text {, coverage of all }(\mathrm{i}, \mathrm{j}, \mathrm{x}) \\
\text { s.t. } \mathrm{j} \in \operatorname{dcu}(\mathrm{x}, \mathrm{i}) \text {. }\end{array}$ & $\begin{array}{l}\text { Dichotomic } \\
\text { [Frankl] }\end{array}$ \\
\hline All-p-uses & & $\begin{array}{l}\text { For each node } i \text { and each } x \in \operatorname{def}(\mathrm{i}) \text {, coverage of all } \\
(\mathrm{i},(\mathrm{j}, \mathrm{k}), \mathrm{x}) \text { s.t. }(\mathrm{j}, \mathrm{k}) \in \operatorname{dpu}(\mathrm{x}, \mathrm{i}) \text {. }\end{array}$ & $\begin{array}{l}\text { Dichotomic } \\
\text { [Frankl] }\end{array}$ \\
\hline All-edges & & Coverage of every edge in a def/use graph. & $\begin{array}{l}\text { Dichotomic } \\
\text { [Frankl] }\end{array}$ \\
\hline All-nodes & & Coverage of every node in a def/use graph. & $\begin{array}{l}\text { Dichotomic } \\
\text { [Frankl] }\end{array}$ \\
\hline
\end{tabular}

\subsection{Other coverage metrics}

\begin{tabular}{|l|l|l|l|}
\hline Names & Symbols & Definitions & References \\
\hline$e$ coverage & $\begin{array}{l}\text { Generic: for any specification or source } \\
\text { code entity type } e \text { (e.g., requirement, } \\
\text { statement, LOC, module, function, class, } \\
\text { branch), the proportion of } e \text { that are } \\
\text { covered. }\end{array}$ & Unit: $\begin{array}{l} \\
\text { cole }\end{array}$ \\
\hline
\end{tabular}




\begin{tabular}{|c|c|c|c|}
\hline Names & Symbols & Definitions & References \\
\hline Path coverage & & $\begin{array}{l}\text { "Test a basis set of paths through the } \\
\text { control flow graph of each module." The } \\
\text { linearly independent paths form a basis } \\
\text { set. } \\
\text { McCabe does not refer to this as path } \\
\text { coverage, but rather "the structured } \\
\text { testing criterion." }\end{array}$ & $\begin{array}{l}\text { Dichotomic } \\
\text { [SP 500-235] }\end{array}$ \\
\hline $\begin{array}{l}\text { Modified } \\
\text { condition/decision } \\
\text { coverage }\end{array}$ & $\mathrm{MC} / \mathrm{DC}$ & $\begin{array}{l}\text { "Every point of entry and exit in the } \\
\text { program has been invoked at least once, } \\
\text { every condition in a decision in the } \\
\text { program has taken all possible outcomes } \\
\text { at least once, every decision in the } \\
\text { program has taken all possible outcomes } \\
\text { at least once, and each condition in a } \\
\text { decision has been shown to } \\
\text { independently affect that decision's } \\
\text { outcome." } 11\end{array}$ & $\begin{array}{l}\text { Dichotomic } \\
\text { [DO-178C] }\end{array}$ \\
\hline $\begin{array}{l}\text { Total variable-value } \\
\text { configuration coverage, } \\
\text { Total } t \text {-way coverage }\end{array}$ & & $\begin{array}{l}\text { For a given combination of } t \text { variables, } \\
\text { the proportion of variable-value } \\
\text { configurations that are covered by at } \\
\text { least one test case in a test set. } \\
\text { This metric depends on the sets of values } \\
\text { that are deemed "valid." Results based } \\
\text { on different sets of valid values are not } \\
\text { mutually comparable. }\end{array}$ & $\begin{array}{l}\text { Unit: } \\
\text { configuration/ } \\
\text { configuration } \\
\text { [Kuhn] }\end{array}$ \\
\hline $\begin{array}{l}\text { Simple } t \text {-way } \\
\text { combination coverage }\end{array}$ & & $\begin{array}{l}\text { For a given test set for } n \text { variables, the } \\
\text { proportion of } t \text {-way combinations of } n \\
\text { variables for which all valid variable- } \\
\text { value configurations are fully covered. } \\
\text { This metric depends on the sets of values } \\
\text { that are deemed "valid." Results based } \\
\text { on different sets of valid values are not } \\
\text { mutually comparable. }\end{array}$ & $\begin{array}{l}\text { Unit: } \\
\text { combination/ } \\
\text { combination } \\
\text { [Kuhn] }\end{array}$ \\
\hline $\begin{array}{l}\text { Linear code sequence } \\
\text { and jump coverage, } \\
\text { Jump-to-jump path } \\
\text { coverage, } \\
\text { Test effectiveness ratio } 3\end{array}$ & TER3 & $\begin{array}{l}\text { The proportion of LCSAJ triples that are } \\
\text { covered. }\end{array}$ & $\begin{array}{l}\text { Unit: } \\
\text { LCSAJ/LCSAJ } \\
\text { [Hennell] }\end{array}$ \\
\hline
\end{tabular}

\section{Security metrics}

The metrics covered in this section are Likert-type scales as used in psychometrics. While arguments have been made that these can be interval scales in Stevens' taxonomy instead of 
merely ordinal, the greater concern is that they may indicate a subjective assessment of a system rather than a measurement of an objective property of a software artifact.

Hash function and cipher metrics are in Sec. 6.2 and 6.3.

\subsection{Common Weakness Scoring System}

The Common Weakness Scoring System (CWSS) defines a number of ordinal quantities where lower values are better. For detailed descriptions of the levels, please refer to [CWSS].

\begin{tabular}{|c|c|c|c|}
\hline Names & Symbols & Definitions & References \\
\hline $\begin{array}{l}\text { Technical } \\
\text { impact }\end{array}$ & TI & $\begin{array}{l}\text { "Potential result that can be produced by the } \\
\text { weakness, assuming that the weakness can be } \\
\text { successfully reached and exploited." } \\
\text { Critical }(\mathrm{C}) / \text { Not applicable }(\mathrm{NA})=1.0 \\
\text { High }(\mathrm{H})=0.9 \\
\text { Medium }(\mathrm{M}) / \text { Default }(\mathrm{D})=0.6 \\
\text { Unknown }(\mathrm{UK})=0.5 \\
\text { Low }(\mathrm{L})=0.3 \\
\text { None }(\mathrm{N})=0.0\end{array}$ & $\begin{array}{l}\text { Ordinal } \\
\text { [CWSS] }\end{array}$ \\
\hline $\begin{array}{l}\text { Acquired } \\
\text { privilege }\end{array}$ & $\mathrm{AP}$ & $\begin{array}{l}\text { "Type of privileges that are obtained by an attacker } \\
\text { who can successfully exploit the weakness." } \\
\text { Administrator (A) / Not applicable (NA) = } 1.0 \\
\text { Partially-privileged user (P) }=0.9 \\
\text { Regular user (RU) / Default (D) }=0.7 \\
\text { Limited / guest (L) =0.6 } \\
\text { Unknown }(\mathrm{UK})=0.5 \\
\text { None }(\mathrm{N})=0.1\end{array}$ & $\begin{array}{l}\text { Ordinal } \\
\text { [CWSS] }\end{array}$ \\
\hline $\begin{array}{l}\text { Acquired } \\
\text { privilege layer }\end{array}$ & $\mathrm{AL}$ & $\begin{array}{l}\text { "Operational layer to which the attacker gains } \\
\text { privileges by successfully exploiting the } \\
\text { weakness." } \\
\text { Application (A) / Enterprise infrastructure (E) / Not } \\
\text { applicable (NA) } 1.0 \\
\text { System (S) / Default (D) = } 0.9 \\
\text { Network (N) =0.7 } \\
\text { Unknown (UK) }=0.5\end{array}$ & $\begin{array}{l}\text { Ordinal } \\
\text { [CWSS] }\end{array}$ \\
\hline $\begin{array}{l}\text { Internal } \\
\text { control } \\
\text { effectiveness }\end{array}$ & IC & $\begin{array}{l}\text { "Ability of the control to render the weakness } \\
\text { unable to be exploited by an attacker." } \\
\text { None (N) / Not applicable (NA) }=1.0 \\
\text { Limited (L) }=0.9 \\
\text { Moderate }(\mathrm{M})=0.7 \\
\text { Default (D) }=0.6 \\
\text { Indirect (I) / Unknown (UK) }=0.5 \\
\text { Best-available }(\mathrm{B})=0.3 \\
\text { Complete (C) }=0.0\end{array}$ & $\begin{array}{l}\text { Ordinal } \\
\text { [CWSS] }\end{array}$ \\
\hline
\end{tabular}




\begin{tabular}{|c|c|c|c|}
\hline Names & Symbols & Definitions & References \\
\hline $\begin{array}{l}\text { Finding } \\
\text { confidence }\end{array}$ & FC & $\begin{array}{l}\text { "Confidence that the reported issue is a weakness } \\
\text { that can be utilized by an attacker." } \\
\text { Proven true (T) / Not applicable (NA) }=1.0 \\
\text { Proven locally true (LT) / Default (D) }=0.8 \\
\text { Unknown (UK) }=0.5 \\
\text { Proven false }(\mathrm{F})=0.0\end{array}$ & $\begin{array}{l}\text { Ordinal } \\
\text { [CWSS] }\end{array}$ \\
\hline $\begin{array}{l}\text { Required } \\
\text { privilege }\end{array}$ & $\mathrm{RP}$ & $\begin{array}{l}\text { "Type of privileges that an attacker must already } \\
\text { have in order to reach the code/functionality that } \\
\text { contains the weakness." } \\
\text { None (N) / Not applicable (NA) }=1.0 \\
\text { Limited / guest (L) = 0.9 } \\
\text { Regular user (RU) / Default (D) }=0.7 \\
\text { Partially-privileged user }(\mathrm{P})=0.6 \\
\text { Unknown (UK) }=0.5 \\
\text { Administrator (A) }=0.1\end{array}$ & $\begin{array}{l}\text { Ordinal } \\
\text { [CWSS] }\end{array}$ \\
\hline $\begin{array}{l}\text { Required } \\
\text { privilege layer }\end{array}$ & RL & $\begin{array}{l}\text { "Operational layer to which the attacker must have } \\
\text { privileges in order to attempt to attack the } \\
\text { weakness." } \\
\text { Application (A) / Enterprise infrastructure (E) / Not } \\
\text { applicable (NA) }=1.0 \\
\text { System (S) / Default (D) = } 0.9 \\
\text { Network (N) = 0.7 } \\
\text { Unknown (UK) }=0.5\end{array}$ & $\begin{array}{l}\text { Ordinal } \\
\text { [CWSS] }\end{array}$ \\
\hline Access vector & AV & $\begin{array}{l}\text { "Channel through which an attacker must } \\
\text { communicate to reach the code or functionality that } \\
\text { contains the weakness." } \\
\text { Internet (I) / Not applicable (NA) }=1.0 \\
\text { Intranet (R) / Private network (V) }=0.8 \\
\text { Default (D) }=0.75 \\
\text { Adjacent network }(\mathrm{A})=0.7 \\
\text { Local (L) / Unknown (U) }=0.5 \\
\text { Physical (P) }=0.2\end{array}$ & $\begin{array}{l}\text { Ordinal } \\
\text { [CWSS] }\end{array}$ \\
\hline $\begin{array}{l}\text { Authentication } \\
\text { strength }\end{array}$ & AS & $\begin{array}{l}\text { "Strength of the authentication routine that protects } \\
\text { the code/functionality that contains the weakness." } \\
\text { None }(\mathrm{N}) / \text { Not applicable (NA) }=1.0 \\
\text { Weak }(\mathrm{W})=0.9 \\
\text { Default }(\mathrm{D})=0.85 \\
\text { Moderate }(\mathrm{M})=0.8 \\
\text { Strong }(\mathrm{S})=0.7 \\
\text { Unknown }(\mathrm{UK})=0.5\end{array}$ & $\begin{array}{l}\text { Ordinal } \\
\text { [CWSS] }\end{array}$ \\
\hline
\end{tabular}




\begin{tabular}{|c|c|c|c|}
\hline Names & Symbols & Definitions & References \\
\hline $\begin{array}{l}\text { Level of } \\
\text { interaction }\end{array}$ & IN & $\begin{array}{l}\text { "Actions that are required by the human victim(s) } \\
\text { to enable a successful attack to take place." } \\
\text { Automated }(\mathrm{A}) / \text { Not applicable }(\mathrm{NA})=1.0 \\
\text { Typical/limited }(\mathrm{T})=0.9 \\
\text { Moderate }(\mathrm{M})=0.8 \\
\text { Default }(\mathrm{D})=0.55 \\
\text { Unknown }(\mathrm{UK})=0.5 \\
\text { Opportunistic }(\mathrm{O})=0.3 \\
\text { High }(\mathrm{H})=0.1 \\
\text { No interaction }(\mathrm{NI})=0.0\end{array}$ & $\begin{array}{l}\text { Ordinal } \\
\text { [CWSS] }\end{array}$ \\
\hline $\begin{array}{l}\text { Deployment } \\
\text { scope }\end{array}$ & SC & $\begin{array}{l}\text { "Whether the weakness is present in all deployable } \\
\text { instances of the software, or if it is limited to a } \\
\text { subset of platforms and/or configurations." } \\
\text { All (A) / Not applicable (NA) }=1.0 \\
\text { Moderate }(\mathrm{M})=0.9 \\
\text { Default }(\mathrm{D})=0.7 \\
\text { Rare }(\mathrm{R}) \text { / Unknown }(\mathrm{UK})=0.5 \\
\text { Potentially reachable }(\mathrm{P})=0.1\end{array}$ & $\begin{array}{l}\text { Ordinal } \\
\text { [CWSS] }\end{array}$ \\
\hline $\begin{array}{l}\text { Business } \\
\text { impact }\end{array}$ & BI & $\begin{array}{l}\text { "Potential impact to the business or mission if the } \\
\text { weakness can be successfully exploited." } \\
\text { Critical }(\mathrm{C}) / \text { Not applicable (NA) }=1.0 \\
\text { High }(\mathrm{H})=0.9 \\
\text { Medium }(\mathrm{M}) / \text { Default }(\mathrm{D})=0.6 \\
\text { Unknown }(\mathrm{UK})=0.5 \\
\text { Low }(\mathrm{L})=0.3 \\
\text { None }(\mathrm{N})=0.0\end{array}$ & $\begin{array}{l}\text { Ordinal } \\
\text { [CWSS] }\end{array}$ \\
\hline $\begin{array}{l}\text { Likelihood of } \\
\text { discovery }\end{array}$ & DI & $\begin{array}{l}\text { "Likelihood that an attacker can discover the } \\
\text { weakness." } \\
\text { High (H) / Not applicable (NA) }=1.0 \\
\text { Medium (M) / Default (D) = } 0.6 \\
\text { Unknown (UK) }=0.5 \\
\text { Low }(\mathrm{L})=0.2\end{array}$ & $\begin{array}{l}\text { Ordinal } \\
\text { [CWSS] }\end{array}$ \\
\hline $\begin{array}{l}\text { Likelihood of } \\
\text { exploit }\end{array}$ & EX & $\begin{array}{l}\text { "Likelihood that, if the weakness is discovered, an } \\
\text { attacker with the required } \\
\text { privileges/authentication/access would be able to } \\
\text { successfully exploit it." } \\
\text { High }(\mathrm{H}) \text { / Not applicable (NA) }=1.0 \\
\text { Medium (M) / Default (D) = } 0.6 \\
\text { Unknown (UK) } 0.5 \\
\text { Low }(\mathrm{L})=0.2 \\
\text { None }(\mathrm{N})=0.0\end{array}$ & $\begin{array}{l}\text { Ordinal } \\
\text { [CWSS] }\end{array}$ \\
\hline
\end{tabular}




\begin{tabular}{|c|c|c|c|}
\hline Names & Symbols & Definitions & References \\
\hline $\begin{array}{l}\text { External } \\
\text { control } \\
\text { effectiveness }\end{array}$ & EC & $\begin{array}{l}\text { "Capability of controls or mitigations outside of the } \\
\text { software that may render the weakness more } \\
\text { difficult for an attacker to reach and/or trigger." } \\
\text { None (N) / Not applicable (NA) }=1.0 \\
\text { Limited }(\mathrm{L})=0.9 \\
\text { Moderate }(\mathrm{M})=0.7 \\
\text { Default (D) }=0.6 \\
\text { Indirect (I) / Unknown (UK) }=0.5 \\
\text { Best-available }(\mathrm{B})=0.3 \\
\text { Complete (C) }=0.1\end{array}$ & $\begin{array}{l}\text { Ordinal } \\
\text { [CWSS] }\end{array}$ \\
\hline Prevalence & $\mathrm{P}$ & $\begin{array}{l}\text { "How frequently this type of weakness appears in } \\
\text { software." } \\
\text { Widespread (W) / Not applicable (NA) }=1.0 \\
\text { High }(H)=0.9 \\
\text { Common }(C)=0.8 \\
\text { Default (D) }=0.85 \\
\text { Limited (L) }=0.7 \\
\text { Unknown (UK) }=0.5\end{array}$ & $\begin{array}{l}\text { Ordinal } \\
\text { [CWSS] }\end{array}$ \\
\hline $\begin{array}{l}\text { Base finding } \\
\text { subscore }\end{array}$ & & $\begin{array}{l}=[(10 \cdot \mathrm{TI}+5 \cdot(\mathrm{AP}+\mathrm{AL})+5 \cdot \mathrm{FC}) \cdot \mathrm{f}(\mathrm{TI}) \cdot \mathrm{IC}] \cdot 4.0 \\
\mathrm{f}(\mathrm{TI})=0 \text { if } \mathrm{TI}=0 \text {; otherwise } \mathrm{f}(\mathrm{TI})=1\end{array}$ & $\begin{array}{l}\text { Ordinal } \\
\text { Range: } 0 \text { to } 100 \\
\text { [CWSS] }\end{array}$ \\
\hline $\begin{array}{l}\text { Attack surface } \\
\text { subscore }\end{array}$ & & {$[20 \cdot(\mathrm{RP}+\mathrm{RL}+\mathrm{AV})+20 \cdot \mathrm{SC}+15 \cdot \mathrm{IN}+5 \cdot \mathrm{AS}] / 100.0$} & $\begin{array}{l}\text { Ordinal } \\
\text { Range: } 0 \text { to } 1 \\
\text { [CWSS] }\end{array}$ \\
\hline $\begin{array}{l}\text { Environmental } \\
\text { subscore }\end{array}$ & & $\begin{array}{l}{[(10 \cdot B I+3 \cdot D I+4 \cdot E X+3 \cdot P) \cdot f(B I) \cdot E C] / 20.0} \\
f(B I)=0 \text { if } B I=0 \text {; otherwise } f(B I)=1\end{array}$ & $\begin{array}{l}\text { Ordinal } \\
\text { Range: } 0 \text { to } 1 \\
\text { [CWSS] }\end{array}$ \\
\hline $\begin{array}{l}\text { CWSS } 1.0 \\
\text { score }\end{array}$ & & $\begin{array}{l}=\text { BaseFindingSubscore } \cdot \text { AttackSurfaceSubscore } \\
\text { EnvironmentalSubscore }\end{array}$ & $\begin{array}{l}\text { Ordinal } \\
\text { Range: } 0 \text { to } 100 \\
\text { [CWSS] }\end{array}$ \\
\hline
\end{tabular}

\subsection{Common Vulnerability Scoring System}

The Common Vulnerability Scoring System (CVSS) ${ }^{12}$ defines a number of ordinal quantities where lower values are better. For detailed descriptions of the levels, please refer to [CVSS].

[CVSS] also defines modified base metrics and an environmental score to characterize the impact of "modifications that exist within the analyst's environment." These have been omitted for brevity. 


\begin{tabular}{|c|c|c|c|}
\hline Names & Symbols & Definitions & References \\
\hline Attack vector & AV & $\begin{array}{l}\text { "Context by which vulnerability exploitation } \\
\text { is possible." } \\
\text { Network }(\mathrm{N})=0.85 \\
\text { Adjacent }(\mathrm{A})=0.62 \\
\text { Local }(\mathrm{L})=0.55 \\
\text { Physical }(\mathrm{P})=0.2\end{array}$ & $\begin{array}{l}\text { Ordinal } \\
\text { [CVSS] }\end{array}$ \\
\hline $\begin{array}{l}\text { Attack } \\
\text { complexity }\end{array}$ & AC & $\begin{array}{l}\text { "Conditions beyond the attacker's control } \\
\text { that must exist in order to exploit the } \\
\text { vulnerability." } \\
\text { Low }(\mathrm{L})=0.77 \\
\text { High }(\mathrm{H})=0.44\end{array}$ & $\begin{array}{l}\text { Ordinal } \\
\text { [CVSS] }\end{array}$ \\
\hline $\begin{array}{l}\text { Privileges } \\
\text { required }\end{array}$ & PR & $\begin{array}{l}\text { "Level of privileges an attacker must possess } \\
\text { before successfully exploiting the } \\
\text { vulnerability." } \\
\text { None }(\mathrm{N})=0.85 \\
\text { Low }(\mathrm{L})=0.62 \text { (if scope }=\mathrm{U} \text { ) or } 0.68 \text { (if } \\
\text { scope }=\mathrm{C} \text { ) } \\
\text { High }(\mathrm{H})=0.27 \text { (if scope }=\mathrm{U} \text { ) or } 0.50 \text { (if } \\
\text { scope }=\mathrm{C})\end{array}$ & $\begin{array}{l}\text { Ordinal } \\
\text { [CVSS] }\end{array}$ \\
\hline $\begin{array}{l}\text { User } \\
\text { interaction }\end{array}$ & UI & $\begin{array}{l}\text { "Requirement for a user, other than the } \\
\text { attacker, to participate in the successful } \\
\text { compromise of the vulnerable component." } \\
\text { None }(\mathrm{N})=0.85 \\
\text { Required }(\mathrm{R})=0.62\end{array}$ & $\begin{array}{l}\text { Ordinal } \\
\text { [CVSS] }\end{array}$ \\
\hline Scope & S & $\begin{array}{l}\text { "Ability for a vulnerability in one software } \\
\text { component to impact resources beyond its } \\
\text { means, or privileges." } \\
\text { Unchanged (U) } \\
\text { Changed (C) } \\
\text { See PR for numerical effect. }\end{array}$ & $\begin{array}{l}\text { Ordinal } \\
\text { [CVSS] }\end{array}$ \\
\hline $\begin{array}{l}\text { Confidentiality } \\
\text { impact }\end{array}$ & $\mathrm{C}$ & $\begin{array}{l}\text { "Impact to the confidentiality of the } \\
\text { information resources managed by a } \\
\text { software component due to a successfully } \\
\text { exploited vulnerability." } \\
\text { High }(H)=0.56 \\
\text { Low }(\mathrm{L})=0.22 \\
\text { None }(\mathrm{N})=0\end{array}$ & $\begin{array}{l}\text { Ordinal } \\
\text { [CVSS] }\end{array}$ \\
\hline $\begin{array}{l}\text { Integrity } \\
\text { impact }\end{array}$ & I & $\begin{array}{l}\text { "Impact to integrity of a successfully } \\
\text { exploited vulnerability." } \\
\text { High }(H)=0.56 \\
\text { Low }(\mathrm{L})=0.22 \\
\text { None }(\mathrm{N})=0\end{array}$ & $\begin{array}{l}\text { Ordinal } \\
\text { [CVSS] }\end{array}$ \\
\hline
\end{tabular}




\begin{tabular}{|c|c|c|c|}
\hline Names & Symbols & Definitions & References \\
\hline $\begin{array}{l}\text { Availability } \\
\text { impact }\end{array}$ & A & $\begin{array}{l}\text { "Impact to the availability of the impacted } \\
\text { component resulting from a successfully } \\
\text { exploited vulnerability." } \\
\text { High }(H)=0.56 \\
\text { Low }(\mathrm{L})=0.22 \\
\text { None }(\mathrm{N})=0\end{array}$ & $\begin{array}{l}\text { Ordinal } \\
\text { [CVSS] }\end{array}$ \\
\hline $\begin{array}{l}\text { Exploit code } \\
\text { maturity }\end{array}$ & $\mathrm{E}$ & $\begin{array}{l}\text { "Likelihood of the vulnerability being } \\
\text { attacked" } \\
\text { High }(\mathrm{H}) / \text { Not defined }(\mathrm{X})=1 \\
\text { Functional }(\mathrm{F})=0.97 \\
\text { Proof-of-concept }(\mathrm{P})=0.94 \\
\text { Unproven }(\mathrm{U})=0.91\end{array}$ & $\begin{array}{l}\text { Ordinal } \\
\text { [CVSS] }\end{array}$ \\
\hline $\begin{array}{l}\text { Remediation } \\
\text { level }\end{array}$ & RL & $\begin{array}{l}\text { Unavailable }(\mathrm{U}) / \text { Not defined }(\mathrm{X})=1 \\
\text { Workaround }(\mathrm{W})=0.97 \\
\text { Temporary fix }(\mathrm{F})=0.96 \\
\text { Official fix }(\mathrm{O})=0.95\end{array}$ & $\begin{array}{l}\text { Ordinal } \\
\text { [CVSS] }\end{array}$ \\
\hline $\begin{array}{l}\text { Report } \\
\text { confidence }\end{array}$ & $\mathrm{RC}$ & $\begin{array}{l}\text { "Degree of confidence in the existence of } \\
\text { the vulnerability and the credibility of the } \\
\text { known technical details." } \\
\text { Confirmed }(\mathrm{C}) / \text { Not defined }(\mathrm{X})=1 \\
\text { Reasonable }(\mathrm{R})=0.96 \\
\text { Unknown }(\mathrm{U})=0.92\end{array}$ & $\begin{array}{l}\text { Ordinal } \\
\text { [CVSS] }\end{array}$ \\
\hline $\begin{array}{l}\text { Confidentiality } \\
\text { requirement }\end{array}$ & CR & $\begin{array}{l}\text { Importance of confidentiality to the } \\
\text { organization. } \\
\text { High }(\mathrm{H})=1.5 \\
\text { Medium }(\mathrm{M}) / \text { Not defined }(\mathrm{X})=1 \\
\text { Low }(\mathrm{L})=0.5\end{array}$ & $\begin{array}{l}\text { Ordinal } \\
\text { [CVSS] }\end{array}$ \\
\hline $\begin{array}{l}\text { Integrity } \\
\text { requirement }\end{array}$ & IR & $\begin{array}{l}\text { Importance of integrity to the organization. } \\
\text { High }(\mathrm{H})=1.5 \\
\text { Medium }(\mathrm{M}) / \text { Not defined }(\mathrm{X})=1 \\
\text { Low }(\mathrm{L})=0.5\end{array}$ & $\begin{array}{l}\text { Ordinal } \\
\text { [CVSS] }\end{array}$ \\
\hline $\begin{array}{l}\text { Availability } \\
\text { requirement }\end{array}$ & AR & $\begin{array}{l}\text { Importance of availability to the } \\
\text { organization. } \\
\text { High }(\mathrm{H})=1.5 \\
\text { Medium }(\mathrm{M}) / \text { Not defined }(\mathrm{X})=1 \\
\text { Low }(\mathrm{L})=0.5\end{array}$ & $\begin{array}{l}\text { Ordinal } \\
\text { [CVSS] }\end{array}$ \\
\hline $\begin{array}{l}\text { Impact sub } \\
\text { score }\end{array}$ & ISC & $\begin{array}{l}\text { If scope }=\mathrm{U}: 6.42 \cdot \text { ISC }_{\mathrm{BASE}} \\
\text { If scope }=\mathrm{C}: 7.52 \cdot\left(\mathrm{ISC}_{\mathrm{BASE}}-0.029\right)- \\
3.25 \cdot\left(\mathrm{ISC}_{\mathrm{BASE}}-0.02\right)^{15} \\
\text { where ISC } \text { ISASE }_{\mathrm{BAS}}=1-[(1-\mathrm{C}) \cdot(1-\mathrm{I}) \cdot(1-\mathrm{A})]\end{array}$ & $\begin{array}{l}\text { Ordinal } \\
\text { [CVSS] }\end{array}$ \\
\hline $\begin{array}{l}\text { Exploitability } \\
\text { sub score }\end{array}$ & ESC* & $\begin{array}{l}8.22 \cdot \mathrm{AV} \cdot \mathrm{AC} \cdot \mathrm{PR} \cdot \mathrm{UI} \\
* \text { [CVSS] does not assign a symbol. ESC } \\
\text { was introduced here to parallel ISC. }\end{array}$ & $\begin{array}{l}\text { Ordinal } \\
\text { [CVSS] }\end{array}$ \\
\hline
\end{tabular}




\begin{tabular}{|c|c|c|c|c|}
\hline Names & Symbols & Definitions & \multicolumn{2}{|l|}{ References } \\
\hline \multirow[t]{7}{*}{ Base score } & & \multirow{7}{*}{$\begin{array}{l}=0 \text { if ISC } \leq 0 \text {. Otherwise, } \\
\text { If scope }=\mathrm{U} \text { : round up(min(ISC+ESC,10)) } \\
\text { If scope }=\mathrm{C} \text { : round } \\
\text { up(min( }(1.08 \cdot(\mathrm{ISC}+\mathrm{ESC}), 10)) \\
\text { where "round up" is defined as the smallest } \\
\text { number, specified to one decimal place, that } \\
\text { is equal to or higher than its input. For } \\
\text { example, round up (4.02) is } 4.1 \text {; and round } \\
\text { up ( } 4.00) \text { is } 4.0 .\end{array}$} & \multicolumn{2}{|c|}{$\begin{array}{l}\text { Ordinal } \\
\text { Range: } 0 \text { to } 10 \\
\text { The scale is further } \\
\text { reduced to a 5-level } \\
\text { ordinal scale as } \\
\text { follows: }\end{array}$} \\
\hline & & & 0.0 & None \\
\hline & & & 0.1 to 3.9 & Low \\
\hline & & & 4.0 to 6.9 & Medium \\
\hline & & & 7.0 to 8.9 & High \\
\hline & & & 9.0 to 10.0 & Critical \\
\hline & & & \multicolumn{2}{|c|}{ [CVSS] } \\
\hline $\begin{array}{l}\text { Temporal } \\
\text { score }\end{array}$ & & $\begin{array}{l}\text { Round up(Base score } \cdot \mathrm{E} \cdot \mathrm{RL} \cdot \mathrm{RC}) \\
\text { See definition of "round up" under base } \\
\text { score. }\end{array}$ & \multicolumn{2}{|c|}{$\begin{array}{l}\text { Ordinal } \\
\text { Range: } 0 \text { to } 10 \\
\text { Reduction to 5-level } \\
\text { scale same as base } \\
\text { score. } \\
\text { [CVSS] }\end{array}$} \\
\hline
\end{tabular}

\subsection{Vulnerability severity (SP 800-30)}

\begin{tabular}{|l|l|l|l|}
\hline Names & Symbols & Definitions & References \\
\hline severity & $\begin{array}{l}\text { Very high = 96 to } 100 \text { (/100) or } 10 \text { (/10) } \\
\text { "The vulnerability is exposed and exploitable, and its } \\
\text { exploitation could result in severe impacts. Relevant } \\
\text { security control or other remediation is not implemented } \\
\text { and not planned; or no security measure can be } \\
\text { identified to remediate the vulnerability." }\end{array}$ & $\begin{array}{l}\text { Ordinal } \\
\text { [SP800-30r1, } \\
\text { Table F-2] } \\
\text { High = 80 to 95 (/100) or 8 (/10) } \\
\text { "The vulnerability is of high concern, based on the } \\
\text { exposure of the vulnerability and ease of exploitation } \\
\text { and/or on the severity of impacts that could result from } \\
\text { its exploitation. Relevant security control or other } \\
\text { remediation is planned but not implemented; } \\
\text { compensating controls are in place and at least } \\
\text { minimally effective." } \\
\text { Moderate = 21 to 79 (/100) or 5 (/10) }\end{array}$ & \\
& $\begin{array}{l}\text { "The vulnerability is of moderate concern, based on the } \\
\text { exposure of the vulnerability and ease of exploitation } \\
\text { and/or on the severity of impacts that could result from } \\
\text { its exploitation. Relevant security control or other }\end{array}$ & \\
\hline
\end{tabular}




\begin{tabular}{|l|l|l|l|}
\hline Names & Symbols & Definitions & References \\
\hline & $\begin{array}{l}\text { remediation is partially implemented and somewhat } \\
\text { effective." } \\
\text { Low } 5 \text { to } 20(/ 100) \text { or } 2(/ 10) \\
\text { "The vulnerability is of minor concern, but effectiveness } \\
\text { of remediation could be improved. Relevant security } \\
\text { control or other remediation is fully implemented and } \\
\text { somewhat effective." } \\
\text { Very low } 0 \text { to } 4 \text { (/100) or 0 (/10) } \\
\text { "The vulnerability is not of concern. Relevant security } \\
\text { control or other remediation is fully implemented, } \\
\text { assessed, and effective." }\end{array}$ & \\
\hline
\end{tabular}

\section{Bibliography}

[Abran] Abran, A. Software Metrics and Software Metrology. Hoboken: John Wiley \& Sons, Inc., 2010.

[Abreu] Fernando Brito e Abreu. "Using OCL to formalize object oriented metrics definitions." Technical Report ES007/2001, version 1.0, June 2001.

https://pdfs.semanticscholar.org/53fb/564942459946ef08ad2b40625a07b0b9187b.pdf.

[AFP] Automated Function Points (AFP), version 1.0. Document formal/2014-01-03, Object Management Group, January 2014. https://www.omg.org/cgi-bin/doc?formal/201401-03.

[Belady] L. A. Belady and C. J. Evangelisti. "System Partitioning and Its Measure." Journal of Systems and Software, 2, pp. 23-29, 1981.

[Berge] Claude Berge. Graphs. North-Holland, second revised edition, 1985.

[Bieman] James M. Bieman and Byung-Kyoo Kang. "Cohesion and Reuse in an Object-

Oriented System." In Proceedings of the 1995 Symposium on Software Reusability

(SSR'95), pp. 259-262. https://doi.org/10.1145/223427.211856.

[Briand93] Lionel C. Briand, Sandro Morasca, and Victor R. Basili. "Measuring and Assessing Maintainability at the End of High Level Design." In Proceedings of the Conference on Software Maintenance (CSM), pp. 88-97, September 1993.

https://doi.org/10.1109/ICSM.1993.366952.

[Briand94] Lionel Briand, Sandro Morasca, and Victor R. Basili. "Defining and validating high-level design metrics." University of Maryland technical report CS-TR 3301, 1994. http://citeseerx.ist.psu.edu/viewdoc/download?doi=10.1.1.31.4744\&rep=rep1\&type=ps

[Briand97] Lionel Briand, Prem Devanbu, and Walcelio Melo. "An Investigation into Coupling Measures for C++." In Proceedings of the 19th International Conference on Software Engineering (ICSE), pp. 412-421, May 1997.

https://doi.org/10.1145/253228.253367.

[Briand98] Lionel C. Briand, John. W. Daly, and Jürgen Wüst. "A Unified Framework for Cohesion Measurement in Object-Oriented Systems." Empirical Software Engineering, 3, pp. 65-117, 1998. 
[Briand99] Lionel C. Briand, John. W. Daly, and Jürgen Wüst. "A Unified Framework for Coupling Measurement in Object-Oriented Systems." IEEE Transactions on Software Engineering, 25(1), pp. 91-121, Jan/Feb 1999.

[Card] David N. Card and Robert L. Glass. Measuring Software Design Quality. PrenticeHall, 1990.

[Chidamber] Shyam R. Chidamber and Chris F. Kemerer. A metric suite for object oriented design. IEEE Transactions on Software Engineering, 20(6), pp. 476-493, June 1994.

https://doi.org/10.1109/32.295895.

[Coleman] Don Coleman, Dan Ash, Bruce Lowther, and Paul Oman. Using metrics to evaluate software system maintainability. Computer, 27(8):44-49, August 1994.

https://doi.org/10.1109/2.303623.

[Conte] S. D. Conte, H. E. Dunsmore, and V. Y. Shen. Software Engineering Metrics and Models. Benjamin/Cummings, 1986.

[COSMIC] Common Software Measurement International Consortium. The COSMIC Functional Size Measurement Method Version 4.0.1 Measurement Manual, April 2015. https://cosmic-sizing.org/publications/measurement-manual-401/.

[Cruickshank] R. D. Cruickshank and J. E. Gaffney, Jr. "Measuring the Development Process: Software Design Coupling and Strength Metrics." In Proceedings from the Fifth Annual Software Engineering Workshop, NASA Goddard Space Flight Center, November 1980. https://ntrs.nasa.gov/search.jsp?R=19820016124.

[CVSS] Common Vulnerability Scoring System v3.0: Specification Document (version 1.8). https://www.first.org/cvss/v3.0/specification-document.

[CWSS] Steve Christey Coley, ed. Common Weakness Scoring System (CWSS) version 1.0.1. MITRE, 2014-09-05. https://cwe.mitre.org/cwss/cwss_v1.0.1.html.

[DO-178C] "Software Considerations in Airborne Systems and Equipment Certification," RTCA DO-178C, December 13, 2011.

[Eder] Johann Eder, Gerti Kappel, and Michael Schrefl. Coupling and cohesion in objectoriented systems. Technical report, University of Klagenfurt, 1994.

http://citeseerx.ist.psu.edu/viewdoc/summary?doi=10.1.1.55.5819.

[Elshoff] James L. Elshoff. "An Analysis of Some Commercial PL/I Programs." IEEE Transactions on Software Engineering, SE-2(2), June 1976, pp. 113-120.

[Embley] D. W. Embley and S. N. Woodfield, "Cohesion and Coupling for Abstract Data Types," in 6th International Phoenix Conference on Computers and Communications (IPCCC), IEEE Computer Society Press, Arizona, 1987, pp. 229-234.

[Fenton] Norman Fenton and James Bieman. Software Metrics: A rigorous and practical approach. CRC Press, 2015.

[Flater] David Flater, "Redressing grievances with the treatment of dimensionless quantities in SI," Measurement v. 109, October 2017, pp. 105-110.

https://doi.org/10.1016/j.measurement.2017.05.043.

[Frankl] Phyllis G. Frankl and Elaine J. Weyuker. "An Applicable Family of Data Flow Testing Criteria." IEEE Transactions on Software Engineering, 14(10), pp. 1483-1498, October 1988. https://doi.org/10.1109/32.6194.

[Halstead] Maurice H. Halstead. Elements of Software Science. Elsevier, 1977.

[Hamer] Peter G. Hamer and Gillian D. Frewin. M. H. Halstead's Software Science-A Critical Examination. In Proceedings of the 6th International Conference on Software Engineering (ICSE'82), September 1982, pp. 197-206. 
[Henderson-Sellers] B. Henderson-Sellers, L. L. Constantine, and I. M. Graham. "Coupling and cohesion (towards a valid metrics suite for object-oriented analysis and design," Object-Oriented Systems, 3(3), 1996, pp. 143-158.

[Hennell] M. A. Hennell, M. R. Woodward, and D. Hedley. "On program analysis." Information Processing Letters, 5(5), November 1976, pp. 136-140.

[Henry] Sallie Henry and Dennis Kafura. "Software Structure Metrics Based on Information Flow." IEEE Transactions on Software Engineering, SE-7(5), pp. 510-518, September 1981. https://doi.org/10.1109/TSE.1981.231113.

[Hitz] Martin Hitz and Behzad Montazeri. "Measuring Coupling and Cohesion In ObjectOriented Systems." In Proceedings of the International Symposium on Applied Corporate Computing (ISAAC'95), October 1995. http://www.isys.uni-klu.ac.at/PDF/1995-0043MHBM.pdf.

[IEC] IEC. Quantities and units-Part 13: Information science and technology, 1.0 edition. IEC 80000-13:2008, http://www.iec.ch/.

[IEEE-100] IEEE 100-2000. The Authoritative Dictionary of IEEE Standards Terms, 7th edition. https://doi.org/10.1109/IEEESTD.2000.322233. Standard withdrawn, DOI broken; use http://ieeexplore.ieee.org/servlet/opac?punumber=4116785.

[IEEE-982.1-1988] IEEE 982.1-1988. IEEE Standard Dictionary of Measures to Produce Reliable Software. https://doi.org/10.1109/IEEESTD.1989.86055. (Superseded) [IEEE-1541] IEEE 1541-2002. IEEE Standard for Prefixes for Binary Multiples. https://doi.org/10. 1109/IEEESTD.2009.5254933. DOI broken; use http://ieeexplore.ieee.org/servlet/opac?punumber=5254929.

[IR5459] W. J. Salamon and D. R. Wallace. NIST IR 5459. Quality Characteristics and Metrics for Reusable Software (Preliminary Report). May 1994.

[IR8113] Paul E. Black and Athos Ribeiro. NIST IR 8113. SATE V Ockham Sound Analysis Criteria. March 2016 (updated May 2019). https://doi.org/10.6028/NIST.IR.8113. [ISO-Vocab-2010] ISO/IEC/IEEE 24765-2010. Systems and software engineeringVocabulary. https://doi.org/10.1109/IEEESTD.2010.5733835. (Superseded)

[ISO-Vocab] ISO/IEC/IEEE 24765:2017. Systems and software engineering-Vocabulary. https://doi.org/10.1109/IEEESTD.2017.8016712.

[ISO-COSMIC] ISO/IEC 19761:2011. Software engineering-COSMIC: a functional size measurement method.

[ISO-FiSMA] ISO/IEC 29881:2010. Information technology—Systems and software engineering-FiSMA 1.1 functional size measurement method.

[ISO-FSM] ISO/IEC 14143-1:2007. Information technology — Software measurementFunctional size measurement, Part 1: Definition of concepts. Second edition, 2007-02-15. [ISO-IFPUG] ISO/IEC 20926:2009. Software and systems engineering—Software measurement - IFPUG functional size measurement method 2009.

[ISO-MkII] ISO/IEC 20968:2002. Software engineering—Mk II Function Point Analysis-Counting Practices Manual.

[ISO-NESMA] ISO/IEC 24570:2018. Software engineering-NESMA functional size measurement method-Definitions and counting guidelines for the application of function point analysis. 2nd ed., 2018-02.

[Knuth] Donald E. Knuth. The Art of Computer Programming, Volume 1: Fundamental Algorithms. 2nd ed. Addison-Wesley, 1973. 
[Krystek] M. P. Krystek. The term 'dimension' in the international system of units. Metrologia 52(2), pp. 297-300, 2015. https://doi.org/10.1088/0026-1394/52/2/297.

[Kuhn] D. Richard Kuhn, Itzel Dominguez Mendoza, Raghu N. Kacker, and Yu Lei. Combinatorial coverage measurement concepts and applications. In Second International Workshop on Combinatorial Testing, Sixth International Conference on Software Testing, Verification and Validation, pp. 352-361, March 2013.

https://doi.org/10.1109/ICSTW.2013.77.

[Lee] Yen-Sung Lee, Bin-Shiang Liang, Shu-Fen Wu, and Feng-Jian Wang. "Measuring the coupling and cohesion of an object-oriented program based on information flow."

Proceedings of the International Conference on Software Quality, Maribor, Slovenia, pp. 8190, 1995.

[Li] Wei Li and Sallie Henry. "Object-oriented metrics that predict maintainability." Journal of Systems and Software, 23(2), pp. 111-122, Nov. 1993. https://doi.org/10.1016/0164-1212(93)90077-B.

[Liso] Aldo Liso. Software maintainability metrics model: An improvement in the Coleman-Oman model. CrossTalk (Journal of Defense Software Engineering), pp. 15-17, August 2001.

http://static1.1.sqspcdn.com/static/f/702523/9456986/1290003183740/200108-Liso.pdf. [Lorenz] Mark Lorenz and Jeff Kidd. Object-Oriented Software Metrics: A Practical Guide. Prentice Hall, 1994.

[Martin] Robert Cecil Martin. Agile software development: principles, patterns, and practices. Prentice Hall, 2003.

[McCabe] Thomas J. McCabe. A complexity measure. IEEE Transactions on Software Engineering, SE-2(4):308-320, December 1976. https://doi.org/10.1109/TSE.1976.233837. [McClure1] Carma L. McClure. "A model for program complexity analysis." Proceedings of the 3rd International Conference on Software Engineering (ICSE), May 1978, pp. 149157. https://dl.acm.org/citation.cfm?id=803205.

[McClure2] Carma L. McClure. Reducing COBOL Complexity through Structured Programming. Van Nostrand Reinhold, 1978.

[Microsoft] Maintainability Index Range and Meaning. In Microsoft Code Analysis Team Blog, 2007-11-20.

https://blogs.msdn.microsoft.com/codeanalysis/2007/11/20/maintainability-index-range-andmeaning/.

[Misa] Subhas Chandra Misra. Modeling design/coding factors that drive maintainability of software systems. Software Quality Journal, 13(3):297-320, September 2005.

https://doi.org/10.1007/s11219-005-1754-7.

[Mohr] Peter J. Mohr and William D. Phillips. "Dimensionless units in the SI." Metrologia, 52(1):40-47, 2015. https://doi.org/10.1088/0026-1394/52/1/40.

[MyersCC] Glenford J. Myers. "An extension to the cyclomatic measure of program complexity." ACM SIGPLAN Notices, 12(10):61-64, October 1977.

https://doi.org/10.1145/954627.954633.

[MyersSD] Glenford J. Myers. Composite/Structured Design. Van Nostrand Reinhold, 1978.

[Oman] Paul Oman and Jack Hagemeister. Construction and testing of polynomials predicting software maintainability. Journal of Systems and Software, 24(3):251-266, March 1994. https://doi.org/10.1016/0164-1212(94)90067-1. 
[Oy] Aivosto Oy. Complexity metrics, Project Analyzer v10.2 help, 2017.

http://www.aivosto.com/project/help/pm-complexity.html.

[Park] Robert E. Park. Software size measurement: A framework for counting source statements. CMU/SEI-92-TR-020, Software Engineering Institute, September 1992.

https://www.sei.cmu.edu/reports/92tr020.pdf.

[Rapps] Sandra Rapps and Elaine J. Weyuker. "Selecting Software Test Data Using Data Flow Information." IEEE Transactions on Software Engineering, SE-11(4), pp. 367-375, April 1985. https://doi.org/10.1109/TSE.1985.232226.

[Schumacher] Benjamin Schumacher. "Quantum coding." Physical Review A, 51(4), April 1995. https://doi.org/10.1103/PhysRevA.51.2738.

[SEI] Software Engineering Institute. Maintainability index technique for measuring program maintainability, in Software Technology Roadmap, May 2008.

https://goo.gl/k2SG1N.

[SI] BIPM. The International System of Units (SI), 9th edition, 2019.

https://www.bipm.org/en/publications/si-brochure/.

[SP500-235] Arthur H. Watson and Thomas J. McCabe. NIST Special Publication 500-235.

Structured testing: A testing methodology using the cyclomatic complexity metric.

September 1996.

[SP800-30r1] NIST Special Publication 800-30 Revision 1. Guide for Conducting Risk

Assessments. September 2012.

[StevensSS] Stanley S. Stevens. On the theory of scales of measurement. Science, 103(2684):677-680, June 1946. https://doi.org/10.1126/science.103.2684.677.

[StevensWP] W. P. Stevens, G. J. Myers, and L. L. Constantine, "Structured Design," IBM Systems Journal, 13(2):115-139, 1974. https://doi.org/10.1147/sj.132.0115.

[Stroud] John M. Stroud. The Fine Structure of Psychological Time. Annals of New York Academy of Sciences, 1966, pp. 623-631.

[UML] Unified Modeling Language version 2.5. OMG document formal/2015-03-01, March 2015. https://www.omg.org/spec/UML/2.5/.

[VIM] Joint Committee for Guides in Metrology. International vocabulary of metrologyBasic and general concepts and associated terms (VIM), 3rd edition. JCGM 200:2012, https://www.bipm.org/en/publications/guides/vim.html.

[Welker] Kurt D. Welker, Paul W. Oman, and Gerald G. Atkinson. Development and application of an automated source code maintainability index. Journal of Software Maintenance: Research and Practice, 9(3):127-159, May 1997. https://goo.gl/pXF5Yd. [Woodward] Martin R. Woodward, Michael A. Hennell, and David Hedley. "A Measure of Control Flow Complexity in Program Text." IEEE Transactions on Software Engineering, SE-5(1), January 1979, pp. 45-50.

[Yourdon] Edward Yourdon and Larry L. Constantine. Structured Design: Fundamentals of a Discipline of Computer Program and Systems Design. Prentice-Hall, 1979.

[Zuse] Horst Zuse. A Framework of Software Measurement. Walter de Gruyter, 1998.

\section{Coleman-Oman maintainability model references}

Fang Zhuo, Bruce Lowther, Paul Oman, and Jack Hagemeister. Constructing and testing software maintainability assessment models. In Proceedings, 1st International Software Metrics Symposium, pages 61-70. IEEE, May 1993.

https://doi.org/10.1109/METRIC.1993.263800. 
[Coleman] Don Coleman, Dan Ash, Bruce Lowther, and Paul Oman. Using metrics to evaluate software system maintainability. Computer, 27(8):44-49, August 1994.

https://doi.org/10.1109/2.303623.

[Oman] Paul Oman and Jack Hagemeister. Construction and testing of polynomials predicting software maintainability. Journal of Systems and Software, 24(3):251-266, March 1994. https://doi.org/10.1016/0164-1212(94)90067-1.

Don Coleman, Bruce Lowther, and Paul Oman. The application of software maintainability models in industrial software systems. Journal of Systems and Software, 29(1):3-16, April 1995. https://doi.org/10.1016/0164-1212(94)00125-7.

Troy Pearse and Paul Oman. Maintainability measurements on industrial source code maintenance activities. In Proceedings, International Conference on Software Maintenance, pages 295-303. IEEE, October 1995. https://doi.org/10.1109/ICSM.1995.526551.

Kurt D. Welker and Dr. Paul W. Oman. Software maintainability metrics models in practice. CrossTalk (Journal of Defense Software Engineering), pages 19-23, 32, November/December 1995.

[Welker] Kurt D. Welker, Paul W. Oman, and Gerald G. Atkinson. Development and application of an automated source code maintainability index. Journal of Software Maintenance: Research and Practice, 9(3):127-159, May 1997. https://goo.gl/pXF5Yd.

\section{Copyright notes}

1 (C) ISO. This material is reproduced from ISO/IEC 14143-1:2007, with permission of the American National Standards Institute (ANSI) on behalf of the International Organization for Standardization. All rights reserved.

2 (C) ISO. This material is reproduced from ISO/IEC 19761:2011, with permission of the American National Standards Institute (ANSI) on behalf of the International Organization for Standardization. All rights reserved.

3 (C) ISO. This material is reproduced from ISO/IEC 20926:2009, with permission of the American National Standards Institute (ANSI) on behalf of the International Organization for Standardization. All rights reserved.

4 (C) ISO. This material is reproduced from ISO/IEC 20968:2002, with permission of the American National Standards Institute (ANSI) on behalf of the International Organization for Standardization. All rights reserved.

5 (C) ISO. This material is reproduced from ISO/IEC/IEEEE 24765:2010, with permission of the American National Standards Institute (ANSI) on behalf of the International Organization for Standardization. All rights reserved.

6 (C) ISO. This material is reproduced from ISO/IEC/IEEE 24765:2017, with permission of the American National Standards Institute (ANSI) on behalf of the International Organization for Standardization. All rights reserved.

7 C ISO. This material is reproduced from ISO/IEC 29881:2010, with permission of the American National Standards Institute (ANSI) on behalf of the International Organization for Standardization. All rights reserved.

8 (C IEC. This material is reproduced from IEC 80000-13:2008, with permission of the American National Standards Institute (ANSI) on behalf of the International Electrotechnical Commission. All rights reserved.

${ }^{9}$ Reprinted with permission from IEEE. Copyright IEEE 1988. All rights reserved.

${ }^{10}$ Reprinted with permission from IEEE. Copyright IEEE 2000. All rights reserved. 
${ }^{11}$ Copyright RTCA, Inc. Used with permission. The complete document may be purchased from RTCA, Inc., $115018^{\text {th }}$ Street NW Suite 910, Washington, DC 20036; (202) 833-9339; www.rtca.org.

${ }^{12}$ CVSS is owned and managed by FIRST.Org, Inc. (FIRST), a US-based non-profit organization. While FIRST owns all right and interest in CVSS, it licenses it to the public freely for use, subject to the conditions below. Membership in FIRST is not required to use or implement CVSS. FIRST does, however, require that any individual or entity using CVSS give proper attribution, where applicable, that CVSS is owned by FIRST and used by permission. Further, FIRST requires as a condition of use that any individual or entity which publishes scores conforms to the guidelines described in the original specification and provides both the score and the scoring vector so others can understand how the score was derived. 